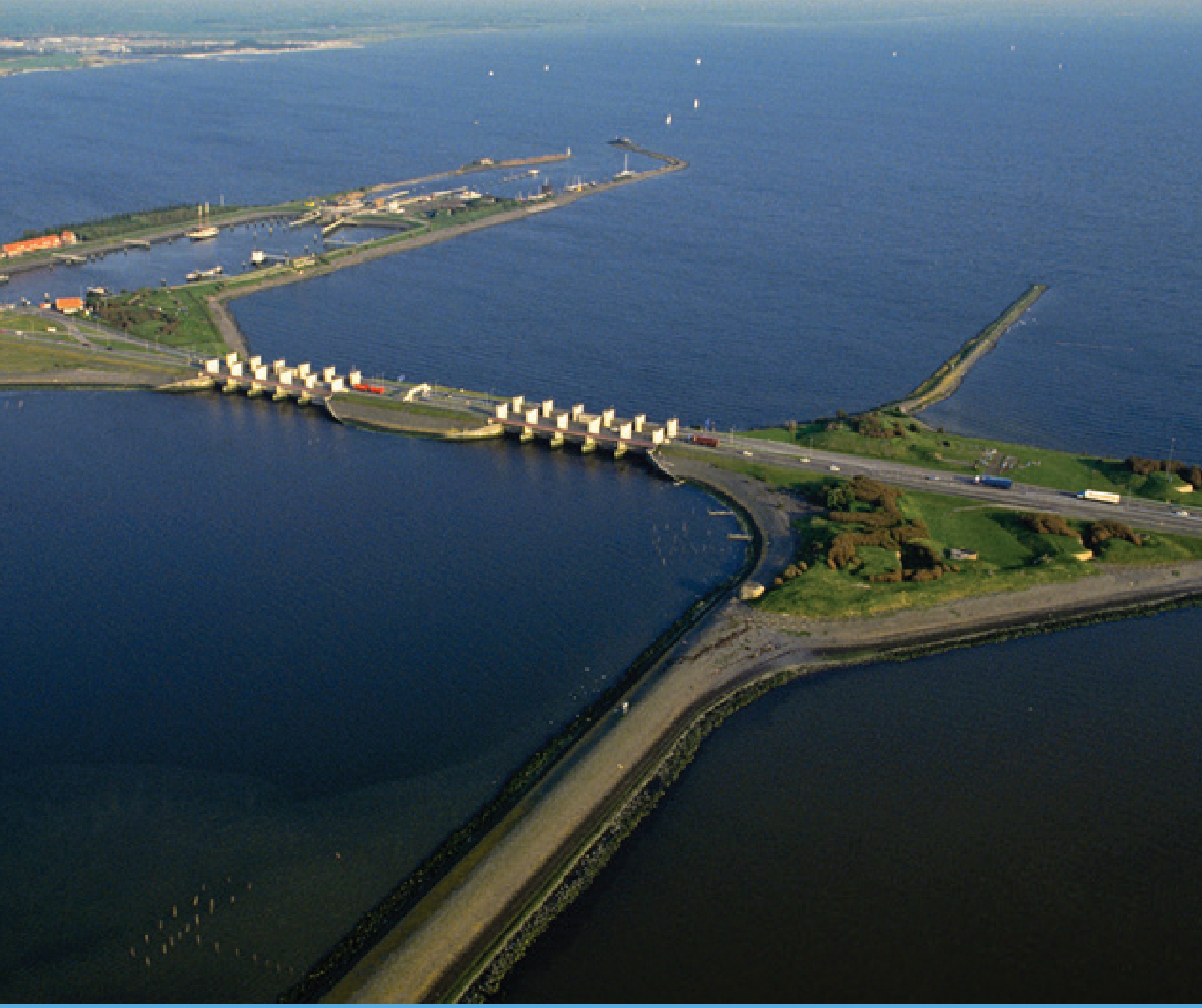

\title{
Contra-expertise rapport
} Milieueffectrapport Windpark Fryslân Deel E Passende Beoordeling

R. Buij, A. Schotman, D. Lammertsma, F.G.W.A. Ottburg 



\section{Contra-expertiserapport Milieueffectrapport Windpark Fryslân Deel E Passende Beoordeling}


Buij, R., A. Schotman, D. Lammertsma, F.G.W.A. Ottburg, 2016. Contra-expertiserapport Milieueffectrapport Windpark Fryslân Deel E Passende Beoordeling. Wageningen, Wageningen Environmental Research, Rapport 2774. 56 blz.; 0 fig.; 6 tab.; 133 ref.

Dit rapport is gratis te downloaden van http://dx.doi.org/10.18174/401104 of op www.wur.nl/environmental-research (ga naar 'Wageningen Environmental Research' in de grijze balk onderaan). Wageningen Environmental Research verstrekt geen gedrukte exemplaren van rapporten.

(C) 2016 Wageningen Environmental Research (instituut binnen de rechtspersoon Stichting Wageningen Research), Postbus 47, 6700 AA Wageningen, T 03174807 00, E info.alterra@wur.nl, www.wur.nl/environmental-research. Wageningen Environmental Research is onderdeel van Wageningen University \& Research.

- Overname, verveelvoudiging of openbaarmaking van deze uitgave is toegestaan mits met duidelijke bronvermelding.

- Overname, verveelvoudiging of openbaarmaking is niet toegestaan voor commerciële doeleinden en/of geldelijk gewin.

- Overname, verveelvoudiging of openbaarmaking is niet toegestaan voor die gedeelten van deze uitgave waarvan duidelijk is dat de auteursrechten liggen bij derden en/of zijn voorbehouden.

Wageningen Environmental Research aanvaardt geen aansprakelijkheid voor eventuele schade voortvloeiend uit het gebruik van de resultaten van dit onderzoek of de toepassing van de adviezen.

Wageningen Environmental Research Rapport 2774 | ISSN 1566-7197

Foto omslag: https://beeldbank.rws.nl, Rijkswaterstaat 


\section{Inhoud}

Dankwoord $\quad 5$

$\begin{array}{ll}\text { Samenvatting } & 7\end{array}$

$1 \quad$ Introductie $\quad 9$

$\begin{array}{lll}1.1 & \text { Vraag- en doelstelling } & 10\end{array}$

1.2 Methode/aanpak/afbakening 10

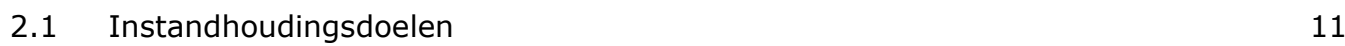

Staat van instandhouding per soort $\quad 13$

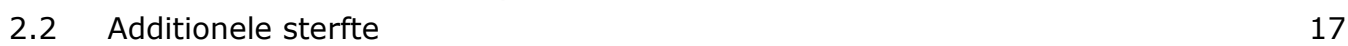

2.3 Aantasting leefgebied $\quad 22$

$\begin{array}{lll}2.4 & \text { Impact additionele sterfte } & 27\end{array}$

$\begin{array}{lll}2.5 & \text { Cumulatie } & 32\end{array}$

$\begin{array}{lll}2.6 & \text { Mitigatie } & 37\end{array}$

$\begin{array}{lll}2.7 & \text { Overige onderwerpen } & 38\end{array}$

$\begin{array}{lll}2.8 & \text { Effecten op vleermuizen } & 40\end{array}$

2.9 Effecten op vissen en amfibieën $\quad 44$

$\begin{array}{ll}\text { Literatuur } & 47\end{array}$ 



\section{Dankwoord}

Wij willen Ruurd Noordhuis (Deltares), Mardik Leopold (Wageningen Marine Research) en Dick Melman (Wageningen Environmental Research) danken voor hun uitgebreide commentaar op deze contraexpertise. 


\section{Samenvatting}

Windpark Fryslân ligt volledig in een Natura 2000-gebied dat speciaal is aangewezen voor behoud van een goede staat van instandhouding van o.a. vogels in Europa; op dit moment is sprake van een ongunstige staat van instandhouding voor veertien vogelsoorten. Daarmee is een volledige beschrijving van de impact van het windturbinepark Fryslân op basis van gedegen onderzoek noodzakelijk, waarbij bovendien het voorzorgsprincipe gehanteerd wordt. Er blijven op dit moment echter een aantal mogelijke gevolgen van het plangebied voor vogelpopulaties onvolledig of niet beschreven in de PB. Hier worden de belangrijkste hiaten nog eens samengevat.

Onduidelijk is of de aannames die zijn gemaakt om parameterwaarden te schatten in het Flux Collision Model gerechtvaardigd zijn, vooral die betreffende aanvaringskansen, vlieghoogtes, ontwijkingsgedrag en toekomstige vliegbewegingen in het plangebied. Het gebrek aan locatie- en soortspecifieke informatie over ontwijkingsgedrag zorgt voor een belangrijke mate van onbetrouwbaarheid in de gegeven schattingen van het aantal aanvaringsslachtoffers. Vlieghoogte van zwarte stern en visdief is bepaald op basis van ervaring (expert judgement), maar nergens wordt toegelicht hoe accuraat die schattingen zijn. Vooral voor visdief en zwarte stern zou door deze hoge mate van onzekerheid de additionele mortaliteit weleens veel hoger kunnen zijn dan nu wordt ingeschat - hoger dan de $1 \%$ mortaliteitsnorm waaronder op dit moment geen negatieve effecten worden verwacht.

Vooral vanwege de onzekerheid van parameterschattingen bestaat er meestal geen duidelijke relatie tussen de voorspelde mortaliteit op basis van modellen en de werkelijke vogelsterfte op windparken, vooral niet op de middellange tot langere termijn. Mocht worden overgegaan tot plaatsing, dan is intensieve monitoring van de mortaliteit door aanvaringen van ten minste de kwetsbare soorten van groot belang, zodat eventuele maatregelen kunnen worden genomen om die mortaliteit te verminderen.

De voor het bepalen van het verstoringseffect gebruikte gemiddelde dichtheden houden geen rekening met de grote temporele en ruimtelijke variatie in de voedselbeschikbaarheid en vogels. Omdat spiering en sterns ruimtelijk geconcentreerd voorkomen in het IJsselmeer, kan het belang van het plangebied (tijdelijk) veel groter zijn dan ingeschat op basis van incidentele tellingen. Mochten dit soort concentraties frequent voorkomen in en rond het plangebied, dan vergroot het de kans op een significant effect door verlies van foerageergebied aanzienlijk. Bij de inschatting van het verlies aan leefgebied worden verder relatief kleine verstoringsafstanden gebruikt die niet zijn toegesneden op de bijzondere situatie of kleiner dan in de literatuur beschreven. De berekende afname aan leefgebied door verstoring wordt daarmee onderschat.

Dat door de aanleg van een vooroever de negatieve effecten van Windpark Fryslân voor alle soorten waarvoor instandhoudingsdoelstellingen zijn gesteld volledig gemitigeerd zijn, lijkt voorbarig. Er vindt geen toename van voedselbeschikbaarheid plaats, de belangrijkste factor die populaties zwarte sterns en visdief beperkt. Het is niet zeker of het aanbod aan vliegende vogels in het plangebied - en daarmee de aanvaringskans - niet zal toenemen ten opzichte van de huidige situatie door de creatie van een belangrijk rustgebied in dit deel van het IJsselmeer.

Er wordt in de PB onvoldoende aandacht geschonken aan gestuwde trek van soorten, additionele sterfte van nachtelijke trekvogels door luchtvaartverlichting die zijn aangewezen als niet-broedvogel in het Natura 2000-gebied IJsselmeer langs de Afsluitdijk. Op dagen van hoge aantallen passerende trekvogels kan de additionele sterfte voor enkele niet-broedvogels aanzienlijk zijn. Effecten op populatieniveau zijn voor kwalificerende soorten als roerdomp, wulp, en bruine kiekendief onvoldoende uitgesloten. 
Het onderzoek geeft een onvoldoende beeld van de aanwezigheid van vleermuizen in het plangebied. Mogelijke effecten op meervleermuizen tijdens de migratie naar winterverblijven zijn onvoldoende onderzocht, evenals het "hoogvlieggedrag" van meervleermuizen bij turbines en de kans op aanvaringen en barotrauma "off-shore". Ook is onvoldoende bekend over de aantrekkende werking door turbines, waardoor secundaire negatieve effecten kunnen optreden. De monitoring van meervleermuizen in Nederland is onvoldoende om nauwkeurige uitspraken te doen over een landelijke populatietrend. De aanname dat significante negatieve effecten kunnen worden uitgesloten op meervleermuizen lijkt daarmee onvoldoende onderbouwd. Cumulatieve effecten op vleermuizen zijn ten onrechte niet meegenomen in de passende beoordeling. $\mathrm{Er}$ is geen gevoeligheidsanalyse gedaan voor de gebruikte parameterwaardes bij mortaliteitsschattingen van ruige dwergvleermuizen, terwijl een eerste aanzet in deze rapportage laat zien dat de additionele sterfte tussen de 0 en $14 \%$ kan liggen. De conclusie dat de additionele sterfte onder de $1 \%$ blijft, is daarmee twijfelachtig.

In de passende beoordeling wordt niet ingegaan op de mogelijke effecten van de windturbines in relatie tot het verspreidingsbeeld van de rivierdonderpad in het IJsselmeer. In de PB is verder geen blijk gegeven of er wel of niet een mogelijke afname van leefgebied is en/of de doorvoerfunctie voor de soorten als zeeprik en zalm wel of niet in het geding komt tijdens de realisatiefase en de uiteindelijke eindfase van het windturbinepark. Tot slot is er nauwelijks aandacht in de PB voor negatieve effecten op vissen van impulsgeluiden bij heiwerkzaamheden en continue geluiden (in respectievelijk de realisatiefase en opleveringsfase), terwijl die wel te verwachten zijn. 


\section{$1 \quad$ Introductie}

In maart 2013 is de Ontwerp-structuurvisie Windenergie op land gepubliceerd. Hierin is het IJsselmeergebied, inclusief Flevoland en de kop van Noord-Holland, opgevoerd als een van de drie concentratiegebieden voor het grootschalig opwekken van windenergie. Deze grootschalige locaties zijn onderdeel van afspraken tussen het kabinet en de provincies over de realisatie van $6000 \mathrm{MW}$ windenergie op land in 2020.

Een van de geplande locaties in het IJsselmeergebied in de Ontwerp-structuurvisie ligt in het IJsselmeer nabij de Afsluitdijk, het zogeheten Windpark Fryslân. Het Windpark Fryslân bestaat uit 89 windturbines met een maximale tiphoogte van 183 meter met turbines die zullen vallen in de 3 en 4 Megawatt (MW) klasse. Het opgesteld vermogen zal op circa $320 \mathrm{MW}$ uitkomen, wat voldoet aan de doelstelling van de provincie Friesland (316 MW).

Het windpark is gelegen in het IJsselmeer. Het IJsselmeer is een Natura 2000-gebied. Daarnaast zijn diverse Natura 2000-gebieden in de omgeving van het windpark gelegen, waaronder de Waddenzee. Voor Natura 2000-gebieden zijn doelstellingen gesteld voor de soorten in het gebied om een gunstige staat van instandhouding te realiseren. Los van het beschermingsregime van deze gebieden vanwege de N2000-status, geldt dat diverse soorten (zowel flora en fauna) individueel zijn beschermd op grond van de Flora- en faunawet.

In het Milieueffectrapport Windpark Fryslân Deel E van de Passende Beoordeling wordt uitgegaan van mogelijk significante effecten, door sterfte en of aantasting van leefgebied op: visdief, zwarte stern, kuifeend, tafeleend, toppereend, dwergmeeuw, fuut, grote zaagbek en brilduiker. Uit de beoordeling komt naar voren dat, voor een aantal vogelsoorten uit Natura 2000-gebied IJsselmeer, significant negatieve effecten op het IJsselmeer ten aanzien van het behalen van de doelen van deze soorten zonder mitigatie niet zijn uit te sluiten. Voor de in de Passende Beoordeling als kwetsbaar gecategoriseerde soorten topper, visdief, dwergmeeuw en zwarte stern zijn de effecten in cumulatie met andere relevante plannen en projecten bepaald en beoordeeld. Voor de soorten waarvoor negatieve effecten uit de effectbeoordeling naar voren kwamen, zijn de effecten na mitigatie en cumulatie beoordeeld.

In de Passende Beoordeling wordt geconcludeerd dat significant negatieve effecten op het behalen van de instandhoudingsdoelstellingen van het IJsselmeer voor deze soorten of de uitbreiding van de omvang en/of kwaliteit van het leefgebied voor soorten met een verbeterdoelstelling - met inbegrip van mitigatie en cumulatie - met zekerheid uitgesloten kunnen worden. De conclusie is dan ook dat het Windpark Fryslân niet tot aantasting leidt van de natuurlijke kenmerken van Natura 2000-gebied IJsselmeer. Verder wordt gesteld dat er geen externe werking op de natuurlijke kenmerken van andere Natura 2000-gebieden zal optreden.

Een aantal natuur- en recreatieorganisaties is bezorgd over de impact van Windpark Fryslân. Er is behoefte aan een contra-expertise van de ecologische effecten zoals vastgesteld in relatie tot de relevante natuurwetgeving die bij de planologische procedures van deze parken spelen. De contraexpertise is het onderwerp van dit rapport. In dit contra-expertiserapport wordt nagegaan of het aannemelijk is dat de ecologische effecten inderdaad niet significant zijn dan wel te mitigeren zijn door de voorgenomen voorzieningen. De contra-expertise gaat in op de volgende soortgroepen waarop een effect op populaties te verwachten is:

- Vogels

- Vleermuizen

- Vissen 


\subsection{Vraag- en doelstelling}

De contra-expertise richt zich op:

- juistheid van de gehanteerde methoden;

- volledigheid van informatie;

- relevante gebieden in beschouwing genomen;

- juistheid van interpretatie van de verwachte effecten;

- adequaat omgegaan met onzekerheden (voorzorgprincipe).

\subsection{Methode/aanpak/afbakening}

We leveren een beoordeling van de bestaande informatie en relevante literatuur, voor de directe effecten van de bouw, effecten tijdens het operationeel zijn van het windpark en van mitigerende en compenserende maatregelen voor de genoemde soortgroepen. We beperken ons tot de relevantste instandhoudingsdoelen en effecten. Omdat bij veel soorten steeds dezelfde onderwerpen terugkeren, wordt de onderbouwing van de passende beoordeling per onderwerp besproken in afzonderlijke hoofdstukken met de volgende onderwerpen:

- Instandhoudingsdoelen, actuele populatieomvang en trends;

- Additionele sterfte;

- Draagkracht van het leefgebied;

- Impact sterfte en verlies leefgebied op populaties;

- Mitigatie;

- Overige onderwerpen. 


\section{Evaluatie van effecten van windpark Fryslân op natuurwaarden}

\subsection{Instandhoudingsdoelen}

De instandhoudingsdoelen voor het IJsselmeer (Tabel 1a en b) hebben al een lange voorgeschiedenis. $\mathrm{Bij}$ het vaststellen van de gebiedsdoelen is er niet uitgegaan van een bepaald referentiejaar, zoals het moment van aanwijzing. Voor het IJsselmeer zijn voor de broedvogels als kwantitatief doel het gemiddelde aantal broedparen over 2007-2011 genomen en voor watervogels het seizoensgemiddelde per maand over de jaren 2007/2008 - 2011/2012. (In de aanvulling MER windpark Fryslân

(17 mei 2016) zijn de implicaties van gebruik van de cijfers van 2009/2010 - 2013/2014 besproken.) Voor gebiedsdoelen Natura 2000 die slaap- of rustplaatsen betreffen zijn (gemiddelde)

seizoensmaxima gebruikt. Op aanwijzing van de Raad van State zijn sommige doelen later naar boven bijgesteld (ABRvSb uitspraaknummer20100284/1/R2). De doelen hebben niet alleen betrekking op het populatieniveau, maar ook op de oppervlakte en de kwaliteit van geschikt leefgebied en er wordt aangegeven of het doel betrekking heeft op behoud of herstel (LNV 2005).

Het IJsselmeer is van nature al een systeem met een grote dynamiek, met de aanleg van de Afsluitdijk en inpoldering is in de oorspronkelijke Zuiderzee een veranderingsproces begonnen dat nog steeds voortduurt. In dat afgesloten meer veranderen de omstandigheden ook nog eens voortdurend door bijvoorbeeld eerst een sterke toename en daarna een sterke afname van de belasting met nutriënten, toename van recreatief gebruik, peilbeheer, etc. Onder invloed van deze veranderingen zag men bij aanwijzing van het IJsselmeer als Vogelrichtlijngebied sterk afnemende aantallen van een groot aantal in 1994 kwalificerende soorten. Daarom is als uitgangspunt de situatie in 2010 genomen (Van Rijn et al. 2010) en zijn de doelaantallen voor de meeste soorten lager gesteld dan de aantallen in de tachtiger jaren tot de Vogelrichtlijn vigerend werd. Bovendien is een studie in het leven geroepen naar de zogenaamde autonoom neergaande trend (ANT) om de optredende processen te doorgronden en adviezen te kunnen geven. In 2014 is het resultaat gepresenteerd: geconcludeerd wordt dat het systeem weliswaar zeer dynamisch is, maar dat doelen uit 2010 in het beheerplan overgenomen kunnen worden en dat maatregelen mogelijk zijn om deze te bereiken (Noordhuis et al. 2014). Tijdens een informatiebijeenkomst over het in de zomer van 2016 te verschijnen beheerplan, is meegedeeld dat inderdaad ook alle geldende doelen zijn overgenomen.

De al lang bestaande traditie van watervogeltellingen is de grondslag voor de wijze waarop in Nederland de kwantitatieve doelen worden geformuleerd (Van Roomen et al. 2000). Voor de meeste soorten gaat het om gemiddelde aantallen per maand over vijf jaren, ook als de aantallen sterk gepiekt zijn in sommige maanden of jaren. Voor de monitoring van de aantallen over lange tijd is deze benadering zeer geschikt. Ook voor evaluatie van het doelbereik met gecontinueerde tellingen is deze methode goed bruikbaar. Bij het beoordelen van effecten zijn die doelaantallen niet vanzelfsprekend een juiste referentie. Vooral van belang voor het berekenen van effecten van maatregelen zijn de maximaal aanwezige aantallen of de totale aantallen die een gebied in de loop van een seizoen gebruiken. Bij een constante doortrek kunnen dat er veel meer zijn dan er maximaal tegelijk aanwezig zijn. Juist door de dynamiek van het systeem en het klimaat kunnen de aantallen per maand, per jaar en per plek sterk variëren. Alleen als er goed wordt gelet op de in het gebied daadwerkelijk verblijvende aantallen, en niet alleen op de kwantitatieve doelen die gemiddelden zijn, wordt de invloed van maatregelen die verlies aan leefgebied of additionele sterfte kunnen veroorzaken goed in beeld gebracht.

Door de veranderlijkheid van het systeem en beperkingen in telcapaciteit (Van der Winden \& Klaassen, 2008 ) is voor een aantal soorten de dynamiek in ruimte en tijd onbekend. Dit is niet zomaar met een kortdurend aanvullend onderzoek op te lossen. Sommige functies die het IJsselmeer vervult, zoals verblijf tijdens de rui, jaarlijks overwinteren of alleen tijdens strenge winters, opvetten voor de trek, etc. zijn niet goed voorspelbaar. De bedoeling van de bescherming als Vogelrichtlijn gebied is echter wel juist al die functies te behouden. 
Tabel 1 a Selectie uit instandhoudingsdoelen IJsselmeer; de staat van instandhouding (SVI) betreft de afwijking van huidige populatiegrootte (huidig) met de doelpopulatie ("draagkracht"). SVI: [--] zeer slecht; [-] slecht; [0]: neutraal; [?] onbekend. Doel = doelstelling uit aanwijzingsbes/uit of zoals geformuleerd door de Raad van State: opp. = oppervlakte; kwal. = kwaliteit([=]: handhaven, [>] verbeteren). Functie: $f=$ foerageren, $s=$ slapen. Draagkracht: doelpopulatie (aantal paren voor broedvogels; aantal exemplaren voor niet-broedvogels). Huidig: huidige populatie cijfers 2009/10 2013/14. Trend: landelijke trend uit Vogelbalans 2015.

\begin{tabular}{|c|c|c|c|c|c|c|c|}
\hline soort & SVI & \multicolumn{2}{|l|}{ Doel } & functie & draagkracht & huidig & trend \\
\hline roerdomp & -- & $>$ & $>$ & broeden & 7 & $4 ?$ & 0 \\
\hline porseleinhoen & -- & $>$ & $>$ & broeden & 18 & $1(2012)$ & 0 \\
\hline bontbekplevier & $?$ & $>$ & $>$ & broeden & 13 & $14(2012)$ & - \\
\hline visdief & $?$ & $=$ & $=$ & broeden & 3300 & 5496 & - \\
\hline fuut & - & $>$ & $>$ & $f$ & $2200 *$ & 1003 & $=$ \\
\hline bergeend & - & $=$ & $=$ & $f$ & 210 & 191 & + \\
\hline smient & -- & $=$ & $=$ & $\mathrm{s}$ & 10300 & 5638 & - \\
\hline grote zaagbek & - & $>$ & $>$ & $f$ & $1850 *$ & 1720 & 0 \\
\hline goudplevier & -- & $=$ & $=$ & $f$ & 9700 & 575 & 0 \\
\hline kemphaan & -- & $=$ & $=$ & $f / s$ & $2100 / 17300$ & $177 / 176$ & - \\
\hline grutto & -- & $=$ & $=$ & $f / s$ & $290 / 2200$ & $102 / 2312$ & - \\
\hline \multirow[t]{3}{*}{ dwergmeeuw } & + & $>$ & $>$ & $f$ & $85 *$ & $39200 * *$ & ? \\
\hline & & & & & & $48 * * *$ & \\
\hline & & & & & & $80 * * * *$ & \\
\hline zwarte stern & -- & $>$ & $>$ & $\mathrm{f} / \mathrm{s}$ & $73200 *$ & 15936 & - \\
\hline
\end{tabular}

* $\quad=$ Verhoogde doel op aanwijzing van de Raad van State.

** Tabel 5.4 en Tabel 4.11 PB (beide met $1 \%$ norm).

*** Tabel 4.8 PB bron NEM cijfers RWS soms ontoereikend.

$* * * *$ Deltares ANT-studie cijfers van periode 2008/9-2012/13.

Er is een sterke relatie tussen het Natura 2000-gebied Waddenzee en het IJsselmeer. Bij de geselecteerde soorten kunnen ontwikkelingen in het IJsselmeer niet los gezien worden van die in de Waddenzee. Formeel-juridisch is dit in beschouwing te nemen als externe werking van het windpark Fryslân op doelen in de Waddenzee of als cumulatie van effecten op doelen van ontwikkelingen in de Waddenzee of van externe werking met cumulatie. Waar populaties in de Waddenzee en het IJsselmeergebied feitelijk functioneren als deel van één populatie (de "flyway"-populatie), zou het effect op die (sub-)populatie getoetst moeten worden (Backes et al. 2011). 
Tabel $1 \boldsymbol{b}$ Instandhoudingsdoelen Waddenzee: gemeenschappelijke soorten met een slechte of twijfelachtige staat van instandhouding in beide gebieden. De staat van instandhouding (SVI) betreft de afwijking van huidige populatiegrootte (huidig) met de doelpopulatie ("draagkracht"). SVI: [--] zeer slecht; [-] slecht; [?] onbekend. Doel = doelstelling uit aanwijzingsbes/uit of zoals geformuleerd door de Raad van State: opp. = oppervlaktegeschikt leefgebied; kwal. = kwaliteit van leefgebied ([=]: handhaven, [>] verbeteren). Functie: $f=$ foerageren, $s=$ slapen (Tabel 3.4 van de PB). Draagkracht: doelpopulatie (aantal paren voor broedvogels; aantal exemplaren voor niet-broedvogels). Huidig: huidige populatie cijfers 2009/10-2013/14. Trend: landelijke trend uit Vogelbalans 2015.

\begin{tabular}{|c|c|c|c|c|c|c|c|}
\hline \multirow[t]{2}{*}{ soort } & \multirow[t]{2}{*}{ SVI } & \multicolumn{2}{|l|}{ Doel } & \multirow[t]{2}{*}{ functie } & \multirow[t]{2}{*}{ draagkracht } & \multirow[t]{2}{*}{ huidig } & \multirow[t]{2}{*}{ trenc } \\
\hline & & Opp. & Kwal. & & & & \\
\hline bontbekplevier & $?$ & $>$ & $>$ & broeden & 60 & 36 & - \\
\hline fuut & - & $>$ & $>$ & $f$ & 310 & 261 & $=$ \\
\hline smient & - & $=$ & $=$ & $f / s$ & 33100 & 27528 & - \\
\hline grote zaagbek & - & $>$ & $>$ & $f$ & 70 & 65 & 0 \\
\hline goudplevier & - & $=$ & $=$ & $f / s$ & 19200 & 15998 & 0 \\
\hline grutto & -- & $=$ & $=$ & $\mathrm{f} / \mathrm{s}$ & 1100 & 615 & - \\
\hline zwarte stern & -- & $>$ & $>$ & $\mathrm{s}$ & 23000 & 3598 & - \\
\hline
\end{tabular}

\section{Staat van instandhouding per soort}

\section{Roerdomp}

De roerdomp slaagt er landelijk maar niet in een populatiepeil van 450-550 paren, zoals in de jaren zeventig, te herstellen. De laatste schatting (https://www.sovon. $\mathrm{nl} / \mathrm{nl} / \mathrm{soort} / 950$ ) is 320-380 paren. De minimale omvang van een duurzame populatie ( $>400$ paren, http://www.synbiosys.alterra.nl/natura2000/documenten/profielen/vogels), en dat is ook de landelijke instandhoudingsdoelstelling, wordt niet gehaald en de landelijke staat van instandhouding is slecht. De laatste tien jaren vindt geen verder herstel plaats. Langs de oevers van het IJsselmeer is de situatie niet anders. De populatie bevindt zich dus in een toestand waarin je geen risico's wilt lopen.

\section{Bruine kiekendief}

In de Waddenzee is de populatie groter dan de doelstelling, maar in het IJsselmeergebied niet. In veel gebieden loopt het broedsucces terug (Bijlsma et al. 2007). Het landelijke instandhoudingsdoel is 1300 paren (Profiel document) en wordt niet meer gehaald: 2010: 1150-1250, sindsdien is er een negatieve trend (Sovon). Net als in het IJsselmeer is de staat van instandhouding nu dus ongunstig in Nederland.

\section{Porseleinhoen, bontbekplevier en kemphaan}

Drie soorten die in het IJsselmeer net als in Nederland als geheel een zeer ongunstige staat van instandhouding hebben: respectievelijk 250-310, 300-360 en 20-55 paren versus landelijke doelstellingen van $>400,>400$ en $>1000$ paren.

\section{Fuut}

Het IJsselmeer is voor de fuut vooral van belang in de maanden augustus tot en met oktober: de ruiperiode. Tot in de jaren negentig herbergde het IJsselmeer een belangrijke ruiconcentratie van circa 10.000 vogels, maar deze aantallen zijn nu aanzienlijk lager. Tegenwoordig verblijven futen ook op andere plekken dan voorheen (Leopold et al. 2011; Van Bemmelen et al. 2013). Het doel is ruimte en draagkracht te behouden voor gemiddeld circa 2.200 exemplaren; veel meer dan het huidige aantal. Om de gewenste draagkracht te bereiken, moet de draagkracht toenemen. Hiervoor is in het bijzonder een toename in de beschikbaarheid van vis van belang. 


\section{Visdief}

Het is niet zeker of de broedpopulatie van Visdieven in het IJsselmeer zich op het gewenste niveau zal kunnen handhaven. Het totale aantal in de regio IJsselmeergebied en Waddenzee was in de jaren 2004-2007 stabiel met circa 10.000 paren, maar er trad een herverdeling van de vogels over kolonies op waarbij een groot aantal vogels uit de Waddenzee naar het IJsselmeer verhuisde. Verhuizingen hebben te maken met het aanbod aan geschikte nestplaatsen, altijd schaars voor deze soort, maar zeker ook met het voedselaanbod in de buurt van die voor broeden geschikte plekken. Zowel in de Waddenzee als het IJsselmeer is het voedselaanbod bij de beschikbare plekken niet optimaal (Stienen et al. 2009; Van Rijn et al. 2010, Van Winden et al. 2008). Belangrijk is om de IJsselmeerpopulatie niet als zelfstandig functionerende populatie te beschouwen, maar als onderdeel van een netwerkpopulatie (Backes et al. 2011).

In de Waddenzee gaat het slecht met de visdief. Volgens de aanvulling op de MER met recentere cijfers van Sovon in de populatie in beide gebieden samen nu $2.134+5.496=7.630$ paren: lager dan het gezamenlijke doel van 8.600 paren. In het IJsselmeer wordt het doel wel gehaald (vooral door hoge aantallen op de Kreupel), maar de staat van instandhouding wordt toch als onvoldoende aangemerkt vanwege een zeer gering broedsucces op de Kreupel (Noordhuis et al. 2014). Het landelijke doel is 20.000 paren van 17.000-18.200 (2014) (profieldocument) wordt niet gehaald.

\section{Kuifeend}

Het doel 11.300 vogels is een seizoensgemiddelde. Dit aantal werd in de periode 2002-2007 bereikt met gemiddeld 11.700 vogels en de volgende vijf jaar met 11.357 vogels. De trend is nu stabiel (Van Roomen et al. 2012). Eigenlijk zouden voor de functie overwinteren en ruien aparte doelen moeten worden geformuleerd (Van Rijn et al. 2010), omdat deze waarschijnlijk een andere voedselniche hebben. Om ook in de toekomst het gemiddelde niveau te kunnen halen, moet de winterpopulatie op het huidige niveau blijven.

\section{Toppereend}

Bij de toppereend zijn de aantallen veel sterker gepiekt dan bij de kuifeend. Het doel op basis van het seizoengemiddelde is met 15.800 niet heel veel hoger dan bij de kuifeend, maar de aantallen in de wintermaanden zijn niet het dubbele, maar het viervoudige. In de meer recentere periode van vijf jaren was het seizoengemiddelde 16.802 vogels. Bij toppers is er bovendien een duidelijke relatie met de aantallen in de Waddenzee. Kennelijk moet het IJsselmeer vogels opvangen als de voedselsituatie in de Waddenzee slecht is (Van Rijn et al. 2010). Net als bij de visdief moet de doelrealisatie in samenhang worden bekeken. De landelijke staat van instandhouding is zeer ongunstig. In IJsselmeer, Markermeer en IJmeer was er in de eerste helft van de jaren negentig sprake van een grote piek in de aantallen toppers die deze wateren als overwinteringsgebied kozen. Na deze periode vielen de aantallen op het IJsselmeer terug naar het niveau van vóór deze piek, maar van Markermeer en IJmeer verdwenen de toppers nagenoeg.

In Waddenzee en IJsselmeer samen is het gezamenlijke seizoengemiddelde wel hoger dan het doel, maar de gunstige referentie in het profieldocument (Min. EZ) is 35.900 vogels en dat aantal wordt niet gehaald. De staat van instandhouding moet daarom als ongunstig worden beschouwd.

\section{Grote zaagbek en andere eenden}

Net als voor kuifeend en toppereend zijn de doelen voor deze overwinteraar al aangepast aan de verslechterde voedselsituatie. De aantallen zijn volgens de meest recente vijfjaarperiode respectievelijk 7\% lager dan de doelstelling. Uit de ANT-studie blijkt dat er mogelijkheden zijn om de voedselsituatie te verbeteren. In de Waddenzee is het aantal grote zaagbekken ook iets afgenomen tot beneden de doelstelling. In tegenstelling tot de bergeend, waarmee het goed gaat in de Waddenzee, is de staat van instandhouding van smient en wilde eend in beide gebieden slecht. Een punt van zorg. 


\section{Zwarte stern}

De ruiende zwarte sterns die jaarlijks het IJsselmeer aandoen, slapen steeds op verschillende plekken, ook buiten het IJsselmeergebied. Constante factor is dat ze grotendeels foerageren op het IJsselmeer (van der Winden \& Klaassen, 2008). Het doelaantal is het gemiddelde maximum dat in één seizoen in het IJsselmeer verblijft. Het is op aanwijzing van de Raad van State van 49.700 bijgesteld naar 73.200. Dit is het gemiddelde van voor 2000. In de jaren daarna gaat het om jaarlijks circa 20.000 vogels (Van Winden \& Klaassen 2008). Volgens de aanvulling op de MER (Sovon) was het gemiddelde aantal in de meest recente periode van vijf jaren 15.936: een afname van ongeveer $20 \%$. Er zijn onzekerheden met betrekking tot de ontwikkeling van de kwaliteit van het leefgebied. Om de belangrijkste functie te kunnen vervullen die het gebied eerst had en om een landelijk gunstige staat van instandhouding te halen, geldt er een verbeterdoelstelling. De aantallen in de dagtellingen wisselen sterk en vertegenwoordigen slechts een klein deel van de aanwezige vogels, omdat deze verspreid over het hele meer voorkomen, terwijl alleen de kuststrook wordt geteld. De slaapplaatstellingen geven een veel betere indicatie van de aantallen die in IJsselmeer en Waddenzee verblijven. Om de neergaande trend te keren, moet de draagkracht op open water verbeteren, niet verslechteren. Uit de ANT-studie blijkt dat er mogelijkheden zijn om de voedselsituatie te verbeteren. Ook is behoud van slaapplekken en rust, ruimte en openheid noodzakelijk.

De doelstelling van Waddenzee en IJsselmeer samen is 96.200 vogels. Het gezamenlijk recente vijfjaargemiddelde is 19.534. Bekend is dat de voedselsituatie is verslechterd (o.a. Van Rijn et al. 2010, Noordhuis et al. 2014). Het IJsselmeergebied vervulde een essentiële rol voor de Europe populatie van aan het eind van de vorige eeuw 57.000 - 110.000 broedparen, waarvan 150.000200.000 exemplaren in augustus hier verbleven (Van Winden \& Viskse, in Hagemeijer et al. 1997; Bijlsma et al. 2001). In diverse bronnen is sprake van oude, slecht onderbouwde negatieve populatietrend (sites Wetlands international, Birdlife international, Profielen document EZ 2008), maar er zijn geen bronnen te vinden die vermelden hoe het nu met de huidige Europese populatie gesteld is of die vermelden waar alle vogels die voorheen in het IJsselmeergebied verbleven, zijn gebleven. Dit sluit niet uit dat de toestand van het IJsselmeer een bottleneck voor de Europese populatie is en dat de ongunstige staat van instandhouding in Europa mede hier veroorzaakt wordt.

\section{Goudplevier, kemphaan en grutto als niet broedvogels}

Het IJsselmeer vervult een belangrijke functie als foerageer- en slaapgebied voor steltlopers. Deze functie komt tegenwoordig niet meer tot haar recht en mag niet verder aangetast worden.

\section{Dwergmeeuw}

Door onbekendheid met de belangrijke functie die het IJsselmeer voor de dwergmeeuw vervult - als gevolg van gebrekkige telmethoden -, is de doelstelling vrij laag voor deze soort. Veel lager dan volgens het verspreidingspatroon in recente jaren en de waargenomen aantallen tijdens de aanvullende tellingen over het héle IJsselmeer in het voorjaar van 2014 (Poot et al. 2010, Heunks et al. 2015). Net als andere doelsoorten is het een viseter waarvoor het twijfelachtig is of de draagkracht voldoende is om in de werkelijke behoefte van de soort te voorzien. Een behoefte die niet correspondeert met de doelstelling. Het is ook niet bekend of er alternatieve gebieden zijn, hoewel grote aantallen verblijven in de Noordzeekustzone in het voorjaar.

\section{Belang van het IJsselmeer}

De functie van Het IJsselmeer voor de dwergmeeuw is een voorbeeld van de functies die het IJsselmeer in het Natura 2000-netwerk vervult voor soorten, maar die niet volledig wordt gedekt door de instandhoudingsdoelen. De dwergmeeuw is maar een van de soorten waarvoor het IJsselmeer een essentiële rol in de levenscyclus vervult (Van Eerden 2001). Door de jaren heen blijft het ecosysteem IJsselmeer voortdurend in ontwikkeling. Steeds weer heeft het gebied een belangrijke functie voor meerdere soorten, maar dat kunnen steeds andere soorten zijn. Daarmee vervult het haar functie in het Natura 2000-netwerk. Bij de beoordeling van ingrepen moet, naast de gekozen kwantitatieve doelen, die brede functie van het IJsselmeer beoordeeld worden, ook voor populaties die slechts een deel van hun levenscyclus in het IJsselmeer doorbrengen. Soms speelt het IJsselmeer een rol als deelgebied voor een deelpopulatie die onderdeel is van een groter netwerk. Waar mogelijk wordt in dit rapport deze netwerkfunctie aangehaald door te verwijzen naar andere Natura 2000-gebieden die, samen met het IJsselmeer, het leefgebied vormen voor de betreffende soorten. 


\section{Conclusies}

Bij het beoordelen van effecten zijn de doelaantallen niet vanzelfsprekend een juiste referentie, vooral omdat de vijfjaargemiddelden niet representatief zijn voor de functie van het dynamische IJsselmeer. Door de veranderlijkheid van het systeem en beperkingen in telcapaciteit is voor een aantal soorten de dynamiek in ruimte en tijd onbekend. Sommige functies die het IJsselmeer vervult, zoals verblijf tijdens de rui, jaarlijks overwinteren of alleen tijdens strenge winters, en opvetten voor de trek zijn niet goed voorspelbaar en ook niet te vatten in kwantitatieve doelen. Er is een sterke relatie tussen het Natura 2000-gebied Waddenzee en het IJsselmeer. Bij de geselecteerde soorten kunnen ontwikkelingen in het IJsselmeer niet los gezien worden van die in de Waddenzee. Waar populaties in de Waddenzee en het IJsselmeergebied feitelijk functioneren als één populatie, zou het effect op die gehele populatie getoetst moeten worden. Bij de beoordeling van effecten zou bovendien meer gekoerst dienen te worden op piekaantallen dan op de seizoengemiddelden. De situatie van de zwarte stern sluit niet uit dat de toestand van het IJsselmeer een bottleneck voor de Europese populatie is en dat deze situatie bijdraagt aan de ongunstige staat van instandhouding in Europa. Er zijn maar liefst zeventien soorten waarbij in de huidige situatie de staat van instandhouding onvoldoende is. Met veel van deze soorten gaat het ook op nationale schaal slecht. 


\subsection{Additionele sterfte}

De PB hanteert het Flux Collision Model om voor specifieke vogelsoorten een voorspelling te doen van het aantal aanvaringsslachtoffers per jaar. Dit is een veelgebruikte methode om te komen tot schattingen van het aantal aanvaringsslachtoffers. Het model schat aanvaringskansen, dat wil zeggen de kans dat een langs vliegende vogel in aanvaring komt met een windturbine en ten gevolge hiervan sterft, op basis van slachtofferonderzoeken in Nederland en België. Deze onderzoeken in artikelen en rapporten (Winkelman 1992a-c; Everaert et al. 2002; Everaert \& Stienen 2007; Fijn et al. 2007; Everaert 2008; Krijgsveld et al. 2009; Verbeek et al. 2012; Prinsen et al. 2013) presenteren aantallen slachtoffers die vervolgens gebruikt zijn om voorspellingen te doen van slachtoffers bij het nieuw geplande windpark met het Flux Collision Model. Bij het schatten van de aantallen slachtoffers is rekening gehouden met de locatie van het windpark (landschapstype), het ontwijkingsgedrag van vogels t.o.v. het windpark en de lokale vogeldichtheid (de zogenaamde flux). In het model wordt bovendien gecorrigeerd voor het aantal windturbines dat vogels passeren als ze het windpark doorkruisen, omdat de aanvaringskans hoger is bij een clusteropstelling zoals Windpark Fryslân dan bij een lijnopstelling. Daarnaast wordt ook rekening gehouden met de hoogte van de turbine-as en het oppervlak dat door de rotoren in beslag wordt genomen. Op basis van de lokale vogelstand en vliegintensiteit, de hoogte van de bewegingen t.o.v. de turbinehoogte, de ontwijking door vogels van de turbines, de configuratie van het windpark en de afmetingen van de windturbines, en bekende aanvaringskansen in referentiewindparken, is voor Windpark Fryslân een inschatting gemaakt van het aantal vogelslachtoffers. In de aanvulling op de MER van 17 mei 2016 wordt speciaal aandacht besteed aan de invloed van de minimale tiphoogte op de voorspellingen van het model.

Hoewel een Flux Collision Model in theorie een betrouwbare schatting kan geven van het aantal verwachte aanvaringsslachtoffers, is er een aantal belangrijke kanttekeningen te plaatsen bij de modelmatige schattingen van het aantal slachtoffers, die hier verder worden besproken (Drewitt \& Langston 2006).

\section{Aanvaringskans}

Sterns, meeuwen en eenden zijn volgens de PB kwetsbaar voor aanvaringen omdat ze ofwel in het donker het plangebied vliegend passeren of er overdag foerageren in hoge dichtheden. Risicovolle vliegbewegingen in het donker bij fuut, aalscholver, brilduiker, grote zaagbek en nonnetje treden volgens de PB hooguit "sporadisch" op (o.a. Poot et al. 1999) en er zijn voor deze soorten om die reden geen aanvaringslachtoffers berekend. Waar sprake is van meerdere aanvaringsonderzoeken worden in de PB enkele onderzoeken die hoge aanvaringskansen laten zien niet gebruikt, omdat (1) het type windturbine in die studies niet overeen zou komen met de te plaatsen turbines, of (2) er sprake zou zijn van lagere aantallen vogels in het geplande windpark in vergelijking met de windparken in de studies (2.2.1 Berekenen van aantallen aanvaringsslachtoffers, pagina 15 van Effecten van Windpark Fryslân op vogels, vleermuizen en overige beschermde natuurwaarden). Dit geldt vooral voor de visdief, waarvoor een aanvaringskans is gehanteerd die bepaald is in het windpark op de Slufterdam (Prinsen et al. 2013). Voor de visdief is ook een aanvaringskans beschikbaar uit een onderzoek van Everaert \& Stienen (2007) in Zeebrugge. Deze aanvaringskans is met $0,007-0,03 \%$ voor alle vluchten (en $0,11-0,118 \%$ voor vluchten op rotorhoogte) ruim 9 keer hoger dan die gemeten in de Slufter $(0,002 \%)$ en dat komt volgens de PB "onder andere doordat het veel kleinere windturbines betreft en er direct naast de turbines een broedkolonie van de visdief aanwezig is". De aanvaringskans gemeten in Zeebrugge is daarom niet meegenomen in de berekeningen, ook niet om een gemiddelde waarde af te leiden.

Bij de keuze voor de berekeningen met de lagere aanvaringskans van visdief zoals gemeten in de Slufter gaat de PB voorbij aan een aantal feiten. De in de aanvulling op de MER aangehaalde referentie (Johnston et al. 2014) met een vlieghoogteprofiel voor de visdief is niet zo maar bruikbaar voor het IJsselmeer, aangezien deze op visdieven waargenomen in de Noordzee is gebaseerd. Hoewel de gerapporteerde vlieghoogtes op het IJsselmeer vergelijkbaar lijken met die van Johnston et al. (2014), zijn de schattingen van vlieghoogte tijdens de aanvullende studie gebaseerd op ervaring van waarnemers ("expert judgement"; Kleyheeg-Hartman et al. 2015). Daarmee blijft onduidelijk hoe accuraat die schattingen zijn, omdat kalibratie achterwege blijft. Hetzelfde geldt voor waarnemingen van vlieghoogtes van zwarte sterns tijdens de seizoenstrek, die (deels) lijken te worden gebaseerd op persoonlijke waarnemingen. 
Hoewel turbinehoogte in sommige gevallen geen effect heeft op aanvaringsrisico's, laat een aantal studies bij vogels juist zien dat slachtofferaantallen hoger kunnen uitvallen bij hogere turbines (bv. Everaert 2003; Marques et al. 2014). De beschikbare studies suggereren in ieder geval dat de relatie tussen de turbinehoogte en aanvaringsrisico niet alleen verschilt tussen soorten, maar ook tussen locaties. Verder zou de dichtheid van visdieven in dit deel van het IJsselmeer dusdanig kunnen toenemen dat het vergelijkbaar wordt met de nabijheid van een broedkolonie. Ook is niet uitgesloten dat met het geplande rustgebied (op ca. $4 \mathrm{~km}$ van het plangebied), het gebruik van het plangebied door visdieven toeneemt. Al met al lijkt het arbitrair en in ieder geval voorbarig om de hogere aanvaringskans voor visdief buiten beschouwing te laten. Wel is het zo dat de door Everaert \& Stienen (2007) gevonden aanvaringskans zodanig hoog is dat het voorspelde aantal slachtoffers voor visdief eveneens veel hoger zou uitkomen (d.w.z. ruim boven de 1\%-mortaliteitsnorm) als deze waarde wel zou zijn gebruikt in de berekeningen. Hierbij kan aangetekend worden dat voor langlevende soorten als visdief significante afnames al kunnen plaatsvinden bij een additieve mortaliteit van 0,1-0,5\% (Everaert \& Stienen 2007).

Bij gebrek aan gegevens is de relatief lage aanvaringskans van visdief vervolgens ook voor zwarte stern gehanteerd om het aantal aanvaringsslachtoffers te berekenen, ondanks het feit dat aanvaringskansen sterk kunnen verschillen (ook tussen soorten uit dezelfde taxonomische familie (Marques et al. 2014)). Omdat bij zwarte sterns sprake is van slaaptrek in augustus en september (Karman et al. 1995; Dirksen et al. 1998; Schobben 1999, 2001, 2004) en de hoogte van die vluchten hoger is dan voor gemiddelde voedselvluchten van visdief waarop de aanvaringskans in het windpark op de Slufterdam gebaseerd is (Prinsen et al. 2013), is het niet onaannemelijk dat aanvaringsslachtoffers bij zwarte stern (veel) hoger uit zullen vallen dan de nu geschatte mortaliteit. Hier komt bij dat de grootste aantallen zwarte stern aanwezig zijn op locaties waar grote scholen spiering aanwezig zijn, maar die concentraties verschillen tussen jaren en ook over de dag. In het betoog, in de aanvulling op de MER, dat voor de flux de effectbeoordeling een worst case scenario is, wordt dit niet meegenomen. Volgens ons klopt dat uitgangspunt dus niet. Met de ontwikkeling van de vismigratierivier net ten oosten van het geplande windpark is onduidelijk of de gegevens m.b.t. concentraties van zwarte sterns representatief zijn voor toekomstige jaren en hoe dat aanvaringsrisico's beïnvloedt. Er bestaat een aanzienlijke kans dat zwarte sterns zich zullen concentreren in dit deel van het IJsselmeer waar de voedselbeschikbaarheid stijgt na ontwikkeling van de vismigratierivier.

Voor eenden wordt in de PB de aanvaringskans gehanteerd zoals bepaald in windpark Oosterbierum voor de nacht, op basis van onderzoek in de jaren tachtig en bij een ander type windturbine dan die gebruikt zullen worden bij Windpark Fryslân (Winkelman 1992a). Ook hier geldt dat aanvaringsrisico's soort-specifiek zijn en nauwelijks tot niet te generaliseren zijn tussen soorten (reviews in Marques et al. 2014, Schuster et al. 2015), zodat het onzeker is of de gebruikte aanvaringskansen een juiste afspiegeling vormen voor tafel-, kuif- en toppereend. Dit is het geval, ook al betreft het hier de enige soort(groep)specifieke aanvaringskans die voor eenden beschikbaar is.

Voor de 6 soorten meeuwen zijn aanvaringskansen uit verschillende onderzoeken in Nederland en België beschikbaar. De betreffende onderzoeken zijn niet gegeven in de PB, dus het is onduidelijk naar welke onderzoeken wordt verwezen. Er wordt gesteld dat de "relevante aanvaringskansen" zijn gebruikt om een voorspelling van het aantal aanvaringsslachtoffers te doen, maar het blijft onduidelijk wat relevant betekent. Een aantal aanvaringskansen van meeuwen uit onderzoek in België zijn buiten beschouwing gelaten, omdat deze als gevolg van de onderzoeksopzet te hoog zouden zijn voor de situatie van Windpark Fryslân. Het is onduidelijk waarom juist de studies die een hogere aanvaringskans laten zien niet relevant worden gevonden.

Over het algemeen geldt voor alle soortgroepen dat aanvaringsgegevens voor de grote moderne windturbines nog vrijwel ontbreken, waardoor aannames over aanvaring moeten worden gedaan - dit is een gebruikelijke methode bij dergelijke evaluaties. Het rotoroppervlak van de turbines die voorzien zijn voor Windpark Fryslân is tot driemaal groter (variant 3 en 4) dan de grootste turbines waarvan in Nederland en België tot nu toe resultaten van slachtofferonderzoek beschikbaar zijn. Grotere rotoren beslaan een groter oppervlak, waardoor de kans dat vogels door de rotor van een turbine vliegen ook groter is. Aan de andere kant is er een kleinere aanvaringskans per vierkante meter rotoroppervlak 
van grotere rotoren in vergelijking met kleine rotoren. Hoewel in de PB getracht is voor het grotere rotoroppervlak en de kleinere aanvaringskans per vierkante meter rotoroppervlak te corrigeren in het Flux Collision Model, is het door gebrek aan aanvaringsgegevens bij dergelijke grote rotoren niet zeker of met die correctiefactor de feitelijke aanvaringskans voldoende wordt benaderd.

\section{Ontwijkingsgedrag}

Wat betreft ontwijkingsgedrag van eenden, waarvoor gecorrigeerd wordt in het Flux Collision Model, zijn schattingen gedaan op basis van (beperkte) observaties boven land voor duikeenden in Windpark Noordoostpolder (Prinsen et al. 2009). De vraag is of dat onderzoek voldoende representatief is voor de situatie midden op het IJsselmeer, waar de zichtbaarheid van de turbines voor vogels mogelijk afwijkt van die door Prinsen et al. (2009) onderzochte turbines. Onderzoek naar uitwijkingsgedrag op windparken worden meestal uitgevoerd in goede weersomstandigheden en bij daglicht.

Vermijdingsgedrag kan echter variëren afhankelijk van de weersomstandigheden, waarbij het afneemt bij slecht zicht bij slecht weer en 's nachts (Winkelman 1992a-b, Still et al. 1996, Longcore et al.

2013). Ook laaghangende bewolking en mist kan ontwijkingsgedrag sterk reduceren. Onder dergelijke omstandigheden hebben vogels bovendien de neiging om verlichting op te zoeken, wat vermijding van verlichte turbines nog verder reduceert (Gauthreaux \& Belser 1999, Manville 2000). Dergelijke weersomstandigheden, die regelmatig voorkomen op het IJsselmeer ${ }^{1}$, kunnen al met al van grote invloed zijn op ontwijkingsgedrag en daarmee het aantal aanvaringen. Bij een offshore onderzoeksplatform bij Helgoland bijvoorbeeld vond meer dan de helft van de vogelaanvaringen (vooral zangvogels) plaats op slechts twee nachten met zeer slecht zicht (Hüppop et al. 2006).

Voor alle sterns en alle meeuwen zijn dezelfde uitwijkingspercentages gebruikt, afkomstig uit een studie bij Offshore Windpark Egmond aan Zee (Krijgsveld et al. 2011). Dit is gedaan omdat er erg weinig betrouwbare, gemeten uitwijkpercentages beschikbaar zijn. Dat wil echter niet zeggen dat de resultaten uit die studie daarmee automatisch van toepassing zijn. Vogels als meeuwen en aalscholvers worden aangetrokken tot turbines als zitplaatsen (Leopold et al. 2013), zeker waar die beperkt aanwezig zijn in voedselrijke gebieden (Fox et al. 2006). Dit kan het ontwijkingspercentage aanzienlijk verlagen, vooral gezien de geplande vismigratierivier en een toename van voedselbeschikbaarheid in het plangebied. Vanwege grote variatie in vermijdingspercentages tussen soorten en locaties zouden voor betrouwbare schattingen van aanvaringskansen de ontwijkingspercentages van dezelfde soorten in hetzelfde landschap gebruikt dienen te worden (Chamberlain et al. 2006). Dit is vooral zo belangrijk omdat een relatief geringe foutschatting van het ontwijkingspercentage (bv. van 10\%) van grote invloed kan zijn op het uiteindelijke geschatte aanvaringsslachtoffers in een Flux Collision Model (Chamberlain et al. 2006). Voor een betrouwbaar ontwijkingspercentage is daarom een in situstudie noodzakelijk en blijft een schatting van aanvaringsslachtoffers gemaakt zonder een dergelijke studie op zijn minst twijfelachtig (Band et al. 2005; Chamberlain et al. 2006). Voor Windpark Fryslân wordt echter volstaan met een mer/PB, terwijl bijvoorbeeld op de Noordzee voor alle offshore windparken (nota bene buiten Natura 2000-gebieden) wél dergelijke in situstudies zijn gedaan (OWEZ, PAWP, Gemini, Luchterduinen).

\section{Verspreiding en voorkomen watervogels}

Voor de effectberekening van de aantallen vogelslachtoffers is uitgegaan van kennis over verspreiding, aantallen in het plangebied en vlieggedrag zoals beschreven in Heunks et al. (2015). Het voorkomen en de verspreiding van watervogels in het onderzoeksgebied is in kaart gebracht met behulp van telgegevens die vanuit het vliegtuig verzameld zijn in de periode 2007/2008 t/m 2011/2014 (RWSWaterdienst en Bureau Waardenburg). De vraag is of deze gegevens representatief zijn voor de periode tijdens en na de bouw van het windpark (operationele fase). Er is op het IJsselmeer sprake van sterke temporele en ruimtelijke variatie in de verspreiding van watervogels, zoals duidelijk weergegeven in de sterke verschillen tussen de dagtellingen van dwergmeeuw (Poot et al. 2014). Dergelijke fluctuaties in aantallen kunnen lokaal aanzienlijk zijn en moeilijk te voorspellen - vooral met het oog op de geplande activiteiten en aan te leggen structuren die een onvoorzien effect op voedselbeschikbaarheid en daarmee soortverspreiding kunnen hebben in het plangebied.

\footnotetext{
1 http://www.klimaatinfo.nl/nederland/ijsselmeer.htm.
} 
Ook is de flux van meeuwen en sterns berekend op basis van de vastgestelde dichtheden in en rond het plangebied. In het broedseizoen is de verspreiding van visdieven over het IJsselmeer geconcentreerd in de nabijheid van de kolonies en in optimale foerageergebieden, die op ruime afstand buiten het plangebied liggen. Om hiervoor te corrigeren, is aangenomen dat tijdens het broedseizoen (mei $\mathrm{t} / \mathrm{m}$ juni) de dichtheid aan visdieven in het plangebied maximaal de helft (50\%) bedraagt van de gemiddelde dichtheid die berekend is voor het gehele onderzoeksgebied. Hierbij is blijkbaar geen rekening gehouden met het te ontwikkelen werkeiland dat zal worden ingericht als broed- en rustgebied voor de sterns en zal bijdragen aan foerageermogelijkheden. Ook de vismigratierivier zal een positieve invloed hebben op foerageermogelijkheden in het gebied ten oosten van het geplande windpark. Onduidelijk is nog of de vismigratierivier oevers zullen hebben, die ook als broedhabitat kunnen dienen. Van overdag sociaal foeragerende groepen aalscholvers is aangenomen dat deze de geplande turbineopstellingen zullen ontwijken, maar dit wordt niet beargumenteerd. Het lijkt echter waarschijnlijk dat aalscholvers de turbineopstellingen juist zullen opzoeken vanwege de (beperkte) zitplaatsen (Leopold et al., 2013; Fox et al. 2006), hoewel nog onzeker is of lokale vogels dit zullen doen. Ook is het niet ondenkbaar dat als de palen van de windturbines op termijn begroeid raken met mosselen die weer ander leven aantrekken - waaronder vis - aalscholvers juist meer gaan foerageren tussen de windturbines en mogelijk meer aanvaringsrisico lopen.

\section{Onbetrouwbaarheid modelvoorspellingen}

Mede gezien de vele variabelen en onzekerheden die een rol spelen bij het doen van modelvoorspellingen over aanvaringsslachtoffers, valt te verwachten dat de werkelijke aantallen slachtoffers afwijken van voorspelde aantallen slachtoffers. Dit kan alleen onderzocht worden voor die windparklocaties waarvan monitoringgegevens beschikbaar zijn van aanvaringsslachtoffers. De beschikbare studies op basis van monitoringsgegevens bevestigen dat het werkelijke aantal slachtoffers soms sterk kan verschillen van het voorspelde aantal slachtoffers. Ferrer et al. (2012) bijvoorbeeld vergeleken gegevens van de feitelijke sterfte onder vogels bij 20 volledig geïnstalleerde windturbineparken met de voorspelde sterfte in 53 MER's. Ze vonden geen relatie tussen voorspelde en werkelijke aantallen slachtoffers. Wel werd een zwakke relatie gevonden tussen mortaliteit van roofvogels en de aantallen roofvogels die windturbineparken doorkruisten. Ook uit de monitoring van slachtoffers bij windparken in Nederland, bijvoorbeeld die in de Eemshaven en Delfzijl-Zuid, blijkt dat er voor sommige soorten vele malen hogere aanvaringsslachtoffers zijn dan wat voorspeld werd (Brenninkmeijer \& van der Weyde 2011; Klop \& Brenninkmeijer 2014). In het windpark Eemshaven bijvoorbeeld werden regelmatig bruine kiekendieven waargenomen die het windpark ook op rotorhoogte doorkruisten (Klop \& Brenninkmeijer 2014), wat regelmatig leidde tot aanvaringsslachtoffers (zes individuen per jaar in 2009-2014), hoewel bruine kiekendief buiten beschouwing werd gelaten als potentieel aanvaringsslachtoffer in de MER. Voor windpark Delfzijl-Zuid werden gemiddeld jaarlijks twee bruine kiekendieven gevonden, terwijl ook hier geen slachtoffers werden verwacht (Brenninkmeijer \& van der Weyde 2011). Voor wulp werden bij windpark Eemshaven voor de vijf jaren van de monitoring in totaal 7 slachtoffers vastgesteld (en 19 slachtoffers voor mogelijk gehouden), naast twee roerdompen, die ook niet voorzien waren (Klop \& Brenninkmeijer 2014). Hoewel het geschatte maximale aantal aanvaringsslachtoffers hoger was dan het daadwerkelijke aantal slachtoffers bij windpark Eemshaven, was het voorspelde soortenspectrum van slachtoffers onder kwalificerende vogelsoorten (19) veel lager dan het gevonden aantal (30 soorten). Het aantal slachtoffers onder trekvogels was een factor 4 lager dan voorspeld, maar de gevonden aantallen slachtoffers pleisterende vogels was weer veel hoger dan de voorspelde aantallen. Van de kwalificerende roofvogels, meeuwen en overige watervogels werden geen slachtoffers voorspeld, maar werden wel enkele tot enige tientallen slachtoffers gevonden. Dergelijke studies onderstrepen nog eens dat modelvoorspellingen in veel gevallen (sterk) kunnen afwijken van de werkelijkheid. Als gevolg hiervan zou enige voorzichtigheid in acht moeten worden genomen met betrekking tot de uitkomst van de modelschattingen, zeker in gevallen waarbij schattingen aanzienlijke sterfte voorspellen onder soorten die toch al onder druk staan en afnemen in aantal. De PB doet dit in onvoldoende mate en stelt dat significante effecten met zekerheid uitgesloten kunnen worden. 


\section{Conclusies}

De input per vogelsoort voor het Flux Collision Model ontbreekt in de PB en onderliggende stukken, zodat niet is na te gaan hoe de mortaliteit door aanvaring wordt geschat. Onduidelijk is of de aannames van parameterwaarden in het model gerechtvaardigd zijn m.b.t. aanvaringskansen, vlieghoogtes en ontwijkingsgedrag. Aanvaringskansen en uitwijkingspercentages voor de kwetsbare soorten (sterns, meeuwen en eenden) zijn gebaseerd op gegevens van verwante soort(groep) of relatief hoge aanvaringskansen worden buiten beschouwing gelaten, waarbij de onderbouwing van die keuze niet altijd voldoende duidelijk is. De PB houdt onvoldoende rekening met de toekomstige ontwikkelingen in het plangebied (vismigratierivier, werkeiland), waardoor onzekerheden bestaan over de toekomstige flux van meeuwen en sterns. Onduidelijk is verder of data uit referentieparken bruikbaar zijn. Dit zorgt voor een belangrijke mate van onbetrouwbaarheid rond de gegeven schattingen van het aantal aanvaringsslachtoffers.

In het kader van de Flora- en faunawet dient het effect van aanvaringsslachtoffers van vogels en vleermuizen op de gunstige staat van instandhouding van de betreffende soorten beoordeeld te worden. Hiervoor is $1 \%$ van de jaarlijkse natuurlijke sterfte (1\%-mortaliteitsnorm) van de betreffende populatie van de soort gebruikt. In de PB wordt de $1 \%$-norm ook gebruikt voor het beoordelen van het effect op de instandhoudingsdoelstelling in het kader van de gebiedsbescherming via de natuurbeschermingswet. De schatting van het te verwachten aantal vogelslachtoffers valt in eerste instantie hoog uit en is ruim boven de $1 \%$-norm voor visdief en zwarte stern. In aanvulling op de MER is dit op basis van een geoptimaliseerd Flux Collision Model en een tiplaagte van 40 meter of de bijgestelde $50 \mathrm{~m}$ niet meer het geval, maar de meeste door ons geplaatste kanttekeningen bij de aangenomen flux blijven gelden. Bij een hoge mate van onzekerheid van de parameterwaarden zou die norm weleens veel sterker kunnen worden overschreden dan nu wordt ingeschat en daarmee zou men het voorzorgsprincipe in acht moeten nemen. Voor langlevende soorten als visdief kunnen significante afnames plaatsvinden bij een additieve mortaliteit van $0,1-0,5 \%$ (Hötker et al. 2006).

Er bestaat meestal geen duidelijke relatie tussen de voorspelde mortaliteit op basis van modellen en de werkelijke vogelsterfte op windparken. Die schatting van de sterfte kan alleen worden verbeterd door studies te concentreren op de locaties van de voorgestelde individuele windturbines en door onderzoek naar de specifieke soort in kwestie. Bij gebrek aan onderzoeksgegevens naar aanvaringsrisico's en uitwijkingsgedrag van zwarte stern en visdief in het IJsselmeer kunnen de gegeven schattingen alleen als ruwe maat worden gebruikt voor de daadwerkelijke mortaliteit. Mocht worden overgegaan tot plaatsing, dan is gedegen monitoring van de mortaliteit door aanvaringen van deze kwetsbare soorten van groot belang, zodat eventuele maatregelen kunnen worden genomen om die mortaliteit te verminderen. Omdat monitoring van het aantal slachtoffers voor windturbines in water problematisch is - of zeer kostbaar moet aan alternatieven worden gedacht, zoals een zenderstudie. Gedacht kan bijvoorbeeld worden aan het uitrusten van een honderdtal sterns in het IJsselmeer met gsm-zenders die hoge, 3D-resolutiedata geven en een nauwkeurige bepaling van mortaliteit door aanvaring.

Al met al concluderen wij dat in de PB onvoldoende is aangetoond dat de additionele mortaliteit van kwetsbare soorten vogels als zwarte stern en visdief tot een niveau beperkt blijft dat d.m.v. mitigatie te beperken is tot beneden de $1 \%$-mortaliteitsnorm. Hiervoor is meer onderzoek vereist naar bijvoorbeeld vlieggedrag en hoogte, zodat de uitspraak dat significante effecten uitgesloten kunnen worden (veel) beter onderbouwd kunnen worden. 


\subsection{Aantasting leefgebied}

In de PB wordt het verlies aan leefgebied door verstoring als gevolg van "een combinatie van de fysieke aanwezigheid van windturbines, de beweging van de rotorbladen en het geluid dat daarbij vrijkomt", ingeschat door per soort het aantal vogels te schatten dat het plangebied zal verlaten of niet meer zal kunnen benutten. Uitgangspunten zijn:

- Er is alleen een effect op soorten die open water benutten. Andere soorten hebben geen binding met het plangebied.

- Per soort wordt een gemiddelde dichtheid berekend gebaseerd op de hoogste aantallen in de periode $2007 / 9$ - 2011/12 voor niet-broedvogels en in 2007-2011 voor broedvogels. In de aanvulling van 17 mei 2016 zijn telgegevens geactualiseerd 2009/10- 2013/14 en 2010-2014.

- De dichtheid in aantal vogels per vierkante kilometer is berekend per telgebied. Voor alle soorten is aangenomen dat deze gelijkmatig verdeeld zijn over de telvakken van RWS-Waterdienst.

- Een soortspecifieke cirkelvormige verstoringszone rondom de windturbine met een bijbehorend percentage verstoorde vogels. Dit percentage verstoorde vogels verlaat het gebied.

- Ook een deel van de vogels in de ruimte tussen de cirkels verlaat het gebied, waardoor het verstoorde effect van de opstelling groter is dan wanneer de verstoring van afzonderlijke turbines wordt gesommeerd.

- Grote turbines hebben geen evenredig groter of kleiner verstorend effect dan kleinere turbines.

Gebruikte dichtheden voor het vaststellen van het verstorend effect

De gevolgde werkwijze in de PB maakt gebruik van dichtheden berekend voor telgebieden in het plangebied om vast te stellen welk deel van de populatie verstoord wordt. De gebruikte dichtheden zijn gebaseerd op tellingen uitgevoerd door Poot et al. (2012, 2014). Tijdens tellingen vanaf het land worden vogels op open water zeker niet waargenomen, waardoor de vliegtuigtellingen van RWS betrouwbare getallen opleveren voor het open water, inclusief het plangebied. Duikeenden rusten overdag voor een deel langs de Afsluitdijk en foerageren 's nachts op mosselen in het open water van het IJsselmeer (Noordhuis 2010, Van Rijn 2010). Deze nachtelijke verspreiding is niet waargenomen tijdens de vliegtuigtellingen. In de aanvulling op de MER wordt dit niet als bezwaar gezien, omdat de dichtheid aan voedsel in het plangebied laag is. De zwarte stern is ook door middel van maandelijkse vliegtuigtellingen moeilijk te inventariseren, omdat doortrekgolven van foeragerende vogels gemist kunnen worden (PB Afsluitdijk, RWS en Ministerie van Infrastructuur en Milieu 2015). Ook hierop wordt ingegaan in de aanvulling op de MER. De aantallen tijdens de seizoenstrek zouden slechts een fractie van het totaal aantal vliegbewegingen zijn. Voor een betrouwbare schatting van de dichtheid zijn zeer veel vlieguren nodig (Roomen et al. 2013). Die waren niet beschikbaar voor de passende beoordeling. De gebruikte dichtheden zijn daarom niet erg betrouwbaar.

De gebruikte dichtheden in de telgebieden zijn bovendien relatief lage dichtheden in vergelijking met een berekende gemiddelde dichtheid voor het hele IJsselmeer op basis van de totale aantallen en de oppervlakte. Vogels zijn niet gelijkmatig verdeeld over het IJsselmeer - niet in de ruimte en niet in de tijd - vooral omdat de verspreiding van bereikbare prooien dynamisch en variabel is (Noordhuis et al. 2014). Hierdoor kunnen er tijdelijk concentraties optreden, bijvoorbeeld van zwarte stern en dwergmeeuw (zie Heunks et al. 2015). Datzelfde geldt voor toppereenden; grote concentraties kunnen in verschillende deeltrajecten aan de ene of de andere zijde van de afsluitdijk aanwezig zijn (PB Afsluitdijk, RWS en Ministerie van Infrastructuur en Milieu 2015). Als dergelijke concentraties optreden in het plangebied is het verlies aan foerageergebied (uitgedrukt in het aantal vogels) groter dan nu in de PB wordt verondersteld. Dit kan ook het geval zijn voor viseters, bijvoorbeeld wanneer scholen spiering zich enige tijd ophouden in het nieuwe windmolenpark en daar onbereikbaar worden als prooi. Zo'n situatie wordt dan feitelijk een bottleneck, omdat de vogels niet meer bij hun prooien kunnen. Het kan ook zijn dat ze dan gedwongen worden in het windpark te foerageren en dan vallen er meer slachtoffers.

Het verschil tussen de gebruikte dichtheid voor de berekening van de verstoring en een gemiddelde dichtheid voor het hele IJsselmeer, gebaseerd op werkelijke aanwezige aantallen, is groot voor genoemde soorten. Voor de zwarte stern bijvoorbeeld wordt een dichtheid van ongeveer 11 vogels per $\mathrm{km}^{2}$ aangehouden op basis van tellingen van Poot et al. (2012). Met als uitgangspunt het instandhoudingsdoel van het IJsselmeer, namelijk dat het gebied plaats moet kunnen bieden aan 
73.200 zwarte sterns en een oppervlakte heeft van 113.340 ha (oppervlakte IJsselmeer in de aanwijzing, LNV 2009), wordt de gemiddelde dichtheid 64,6 vogels per km², d.w.z. bijna zes keer de gebruikte dichtheid. Uitschieter is de toppereend $\left(87,0\right.$ vogels per $\mathrm{km}^{2}$ als gemiddelde dichtheid van de doelstelling versus 1,29 per $\mathrm{km}^{2}$ voor de gehanteerde dichtheid). Voor kuifeend en tafeleend zijn die dichtheden respectievelijk 41,9 per $\mathrm{km}^{2}$ en 9,6 per $\mathrm{km}^{2}$ versus 0 individuen per $\mathrm{km}^{2}$. Het hierbij gebruikte argument in de PB is dat de duikeenden zich concentreren in een strook van 100-200 m van de Afsluitdijk. Echter, deze eenden zullen ook aangrenzende gebieden gebruiken als foerageergebied, hoewel dit onaannemelijk wordt geacht in de PB. Echter, de in de aanvulling op de MER gebruikte kaart van de verspreiding van voedsel voor de toppereend (Figuur 4.3 blz. 23) geeft slechts een momentopname weer. Zie ook Noordhuis 2010, Figuur 5.4.4. De verspreidingskaarten van de verschillende mosselsoorten (Noordhuis et al. 2014) laten bovendien zien dat belangrijke voedselsoorten voor duikeenden voorkomen in het plangebied, hoewel de beschikbaarheid daarvan ook afhangt van de diepte en vleesinhoud.

Uitzondering op bovenstaande onderschatting van dichtheden is de visdief. Voor deze soort wordt een dichtheid aangehouden die in de buurt komt van een dichtheid op basis van een seizoenmaximum. Bijvoorbeeld 15.000 vogels in augustus 2007 (Van der Winden \& Klaasen 2008). Daarbij wordt de kanttekening geplaatst dat er alleen een doelstelling is voor broedende visdieven en dat het bij het draagkrachtverlies vooral om niet-broedvogels gaat, wat juist lijkt. De berekende verstoring kan volgens de PB als "geen maatgevende verstoring" beschouwd worden, wat een twijfelachtige aanname is, omdat de broedvogels van het IJsselmeer zich buiten het broedseizoen vrijwel zeker ook in het plangebied ophouden. Tijdens het broedseizoen is er geen directe functie van het plangebied voor de broedvogels, maar daarbuiten wel. Met dit verlies aan leefgebied voor de broedvogels wordt onvoldoende rekening gehouden door het weg te zetten als niet "maatgevend" en daarom verder buiten beschouwing te laten. Al eerder is opgemerkt dat de visdieven van de Waddenzee en het IJsselmeer één samenhangende populatie vormen van ruim 10.000 paren (Van Rijn 2005; Van Rijn et al. 2010; Noordhuis et al. 2014). Verlies van habitat voor vogels afkomstig uit de hele populatie, van waar dan ook, werkt door op lokaal niveau in de IJsselmeerpopulatie.

\section{Verstoringsafstand}

De voor de berekening van aantallen verstoorde vogels gebruikte soortspecifieke verstoringsafstand, inclusief het bijbehorend verstoord percentage (\%) vogels binnen die zone (naar Prinsen et al. 2009), Tabel 2.2 blz. 460, is voor de meeste soorten slechts $50-150 \mathrm{~m}$ met een percentage van $75-90 \%$. Eidereenden vertoonden echter in het donker tot op 1,500 $\mathrm{m}$ van een windpark in het water een lagere vliegactiviteit (Dirksen et al. 2009). Op zee gevonden uitwijkingen met als gevolg lagere dichtheden binnen het park wijzen op verschillen tussen windparken, locaties en turbinetypes (Leopold et al. 2013); effecten van verstoring waren meetbaar tot op kilometers van windparken op zee. De soorten met een significant lagere dichtheid binnen in vergelijking met buiten een windpark op de Noordzee in deze studie, zijn o.a. fuut en visdief. Deze kennis is niet meegenomen in de passende beoordeling.

De effecten van het geluidsniveau binnen en buiten het park blijven onderbelicht, ook omdat ze niet of nauwelijks te onderscheiden zijn van visuele verstoring. Het is niet zeker dat de gehanteerde verstoringsafstanden ook gelden voor de specifieke situatie van het IJsselmeer(gebied), noch of de verstoringsafstanden ook gelden voor het soort werkzaamheden voor het windpark. Aangezien de aanleg van het windpark gedurende een lange periode plaatsvindt (onderbreking tijdens periodes van extra gevoeligheid van soorten, bijvoorbeeld ruiperiodes, is niet voorgeschreven), is niet zeker dat de gehanteerde verstoringsafstanden ieder moment van toepassing zijn.

De aanname dat grote turbines (3 MW en groter) geen evenredig groter of kleiner verstorend effect hebben dan turbines van de eerste generatie, is gebaseerd op gedateerde informatie die mogelijk weinig representatief is voor nieuwe generatie windturbines. Onderzoek laat zien dat hogere windturbines in sommige gevallen (afhankelijk van configuratie) wel een grotere verstoringsafstand hebben dan kleinere turbines (Marques et al., Schuster et al. 2015). 
Ook aan wel of niet optreden van gewenning aan de extra vaarbewegingen en aanwezigheid van materieel en mensen wordt nauwelijks aandacht besteed, behoudens de opmerking dat gewenning mogelijk zal optreden. Hoewel de respons van vogels kan variëren tussen soorten kan worden verwacht dat gewenning aan windturbines minder groot is in gebieden waar vogels minder tijd spenderen, bijvoorbeeld tijdens de migratie.

Ook is niet zeker of er voldoende geschikte alternatieve rust- en foerageergebieden aanwezig zullen zijn; de vogels concentreren zich in optimale gebieden en uitwijken naar suboptimale gebieden kan negatieve effecten met zich meebrengen met onbekende gevolgen op populatieniveau (bv. door lager voedselaanbod in die suboptimale gebieden).

\section{Conclusies}

Het ligt voor de hand dat de functie van het plangebied als leefgebied door dynamiek in de verspreiding van voedsel in sommige jaren belangrijker is dan gesuggereerd op basis van de aangenomen lage dichtheden in de PB. In jaren dat juist in het plangebied het meeste voedsel beschikbaar is, wordt dit minder bereikbaar door realisatie van het windpark. Dit kan dan niet elders gecompenseerd worden en de populaties gaan dan door een bottleneck of worden gedwongen te foerageren tussen de windturbines met mogelijk een hogere sterfte door aanvaringen of een lagere voedselopname door verstoring als gevolg.

Incidentele tellingen zoals de in de PB-beoordelingen beschreven tellingen (Poot et al. 2014) kunnen niet uitwijzen hoe groot de kans is dat de vogels zich in het plangebied concentreren. Een twee- (gemiddeld aanwezig) tot zesmaal (op basis van doelstelling) hogere dichtheid zoals voor de zwarte stern zou een belangrijk verlies aan foerageergebied kunnen opleveren, als de voedselsituatie in het plangebied gedurende langere tijd gunstig is. Het is onbekend hoe vaak zich dit voordoet. Mochten dit soort concentraties langdurig voorkomen, dan vergroot het de kans op een significant effect door verlies van foerageergebied aanzienlijk.

Bij de inschatting van het verlies aan leefgebied worden relatief kleine verstoringsafstanden gebruikt die niet zijn toegesneden op de bijzondere situatie of kleiner dan (ook) in de literatuur beschreven. De berekende afname aan leefgebied door verstoring wordt daarmee mogelijk onderschat. 


\section{ANT-IJsselmeergebied}

De PB berekent het verstoorde areaal leefgebied op een eenvoudige manier. Dit doet geen recht aan de complexiteit van het IJsselmeer systeem zoals dat recentelijk beschreven is in een uitgebreide studie. Van de inzichten in deze studie, bv. over de dynamiek van het systeem in ruimte en tijd, is nauwelijks gebruikgemaakt. Aan het wetenschappelijk eindadvies van de studie ANT-IJsselmeergebied (Noordhuis et al. 2014) is vijf jaar door een projectgroep van tientallen onderzoekers, waaronder vijf aio's, verdeeld over zes clusters, gestudeerd op de kansen voor het ecosysteem van het IJsselmeer, Markermeer en IJmeer met het oog op de Natura 2000-doelen. De aanleiding was twijfel over de haalbaarheid van deze doelen als gevolg van grote veranderingen, gepaard gaand met neergaande trends voor een aantal doelsoorten. De resultaten van deze ANT-studie vormen de basis voor een advies over haalbare en uitvoerbare Natura 2000-doelen. Dit advies is gebruikt voor het Natura 2000-beheerplan dat in deze zomer (2016) gepubliceerd wordt. In voorlichtingsbijeenkomsten is al meegedeeld dat de bestaande doelen gehandhaafd zijn.

De ANT-(Autonome Neergaande Trend)studie gaat in op de volgende vragen:

- Welke mechanismen in het IJsselmeergebied zijn de grootste veroorzakers van de neergaande trends?

- Zijn de huidige instandhoudingsdoelen haalbaar zonder aanvullende maatregelen?

- Welke maatregelen zijn effectief om de instandhoudingsdoelen te bereiken?

- Welke niveaus van instandhoudingsdoelen kunnen worden bereikt tegen welke financiële inspanning?

De ANT-studie in het IJsselmeergebied heeft betrekking op tien soorten watervogels die in het IJsselmeer, Markermeer en IJmeer voorkomen en die voorafgaand aan de formulering van de Natura 2000instandhoudingsdoelen in aantal zijn afgenomen. Het betreft vier soorten die zich voeden met ongewervelde bodemdieren ("benthoseters"), kuifeend, tafeleend, topper en brilduiker, en zes soorten viseters: fuut, grote zaagbek, nonnetje, visdief, zwarte stern en dwergmeeuw. Veel veranderingen hebben zich in een relatief korte tijd gedurende de jaren negentig voorgedaan. Hoewel bij sommige soorten al in de tweede helft van de jaren tachtig sprake is van een neergaande trend, zijn de afnames vooral sterk rond 1996. In het Markermeer-IJmeer is de neergaande trend sterker dan in het IJsselmeer. Vanwege de afname van Driehoeksmossel en Spiering in het IJsselmeergebied is in het ANT-onderzoek de focus gelegd op de rol van afnemende voedselbeschikbaarheid als oorzaak voor neergaande vogeltrends, in combinatie met het ontbreken van geschikte alternatieve prooisoorten door de lage (habitat)diversiteit.

\section{Enkele conclusies van de systeemanalyse}

De autonome neergaande trends van de watervogels in het IJsselmeergebied zijn grotendeels in de regio zelf veroorzaakt. Door afname van nutriënten is, meer dan de primaire productie, vooral de kwaliteit van algen als voedsel en als basis van de rest van het voedselweb verslechterd. Vanaf begin jaren negentig is de productie van zoöplankton (onder andere voedsel voor spiering) alsook de kwaliteit van resterende algen verminderd. De voedingswaarde van mosselen is sinds die tijd ook sterk verslechterd. Het aandeel grotere Spiering in de spieringpopulatie is afgenomen, maar aanvankelijk gecompenseerd door relatief grote hoeveelheden kleine Spiering. Begin jaren negentig, toen ook de samenstelling en voedingswaarde van het fytoplankton veranderde, nam ook de kleine Spiering af. De overgebleven "mossel-etende" watervogels zijn inmiddels gedeeltelijk overgestapt op andere prooisoorten, zoals slakjes, erwtenmosseltjes en vlokreeftjes. Er heeft geen herstel van de vogelpopulaties plaatsgevonden als reactie op de opmars van de Quaggamossel. De toename van Quaggamosselen heeft geleid tot een toename in helderheid van het water in het voorjaar, in het zuidelijke IJsselmeer en het IJmeer, waardoor ondiep duikende visetende vogels (Dwergmeeuw, Visdief en Zwarte Stern) in deze gebieden weinig Spiering vinden (omdat die liever in minder helder water zit).

Voor de meeste doelsoorten zijn instandhoudingsdoelen niet haalbaar zonder aanvullende maatregelen. De autonome trends in de waterkwaliteit zetten door. Het ecosysteem tendeert daarmee naar een lagere draagkracht. Doelsoorten spelen weliswaar in op veranderend voedselaanbod, maar dit is bij de meeste soorten onvoldoende om de instandhoudingsdoelen te halen. Ingrepen met een negatieve invloed op de draagkracht van het systeem door het onttrekken van habitat, kunnen de situatie, die al ondermaats is, alleen maar verder verslechteren.

\section{Conclusies naar aanleiding van ANT-studie}

Uit het voorgaande blijkt dat het IJsselmeersysteem zwaar onder druk staat. De PB zou dus zeer zorgvuldig moeten zijn en moeten onderzoeken of de extra verliezen als gevolg van het windpark de veerkracht van de soorten niet nog verder aantast. Er wordt echter geen rekening gehouden met een uit de ANT-studie af te leiden geringere veerkracht. Extra maatregelen met juist een positief effect zijn nodig, terwijl nieuwe ingrepen met negatieve effecten, hoe klein ook, de doelen nog verder aantasten.

Met een zware procedure zijn de doelen aan te passen en waarschijnlijk beter haalbaar te maken, maar aangezien het IJsselmeer een dynamisch systeem is, zal de ecologische functie steeds blijven veranderen. In een Natura 2000-gebied zou optimale ontwikkeling van die functies mogelijk moeten zijn. Als men die ecologische functie centraal stelt, lijkt geen andere keuze mogelijk dan op zoek te gaan naar alternatieve locaties voor de geplande windturbines.

Een andere optie is wellicht door natuurontwikkeling in en buiten het IJsselmeergebied de landelijke staat van instandhouding van de soorten die nu al een slechte staat van instandhouding hebben sterk te verbeteren, waardoor het mogelijk wordt enige verliezen door windturbines te accepteren. Deze compensatieoptie is pas aan de orde als er geen alternatieven zijn voor de huidige locatie. 


\section{Effectieve Maatregelen voor realisatie instandhoudingsdoelen}

Het IJsselmeer is een dynamisch systeem dat voortdurend aan veranderingen onderhevig is. Zonder aanvullende maatregelen zijn de instandhoudingsdoelstellingen niet haalbaar. De ANT-vogelsoorten reageren sterk op de daling in aantallen van hun 'klassieke' prooisoorten (Driehoeksmossel en Spiering) als gevolg van de afname van de aanvoer van nutriënten. De hoofdoorzaak van de neergaande trends, de afname van de hoeveelheid voedingsstoffen, kan niet structureel met maatregelen worden weggenomen. Dat komt omdat die afname een gevolg is van enkele decennia van beleid ter bestrijding van eutrofiëring, uiteindelijk vastgelegd in de normen van de Europese Kaderrichtlijn Water. Dit is een hoger doel dan de Natura 2000-doelen voor het IJsselmeer: dit natuurgebied is geen visvijver of vogelkweekgebied, maar een natuurgebied. De vigerende doelen zijn wellicht niet in overeenstemming met de nieuwe, natuurlijke staat van het gebied en zouden wellicht naar beneden moeten worden bijgesteld. De hoofdoorzaak is mogelijk versterkt door andere processen als klimaatverandering, menselijke verstoring, visserij en te weinig diversiteit (waardoor de vogels weinig prooikeuze hebben). Effectieve maatregelen zijn echter mogelijk, welke gepaard kunnen gaan met aanzienlijke kosten.

In het kader van ANT is de omvang van maatregelen uitgewerkt in adviezen aan programma's als Toekomst Bestendig Ecologisch Systeem (TBES) en in de vorm van een grove kostenindicatie. De voor het behalen van de instandhoudingsdoelen benodigde omvang van de gewenste habitats is tot voor kort voornamelijk ontleend aan de indeling in ecologische zones (dieptezones) van vergelijkbare meren met een natuurlijke inrichting, met name het meer Peipsi in Estland. In de PB is geen gebruikgemaakt van deze schattingen van wat voor het bereiken van de doelstellingen nodig is. Er zijn slechts beperkt pogingen ondernomen om de afname in draagkracht te schatten, zonder aandacht te besteden aan de verhouding tussen de huidige en de voor het behalen van de doelstellingen noodzakelijke draagkracht. Het verlies aan leefgebied door realisatie van het windpark maakt de schaarste nog groter dan die al is en staat herstel van de draagkracht in de weg.

\section{Conclusies}

Door ontwikkelingen in het verleden is de draagkracht van het systeem IJsselmeer t.a.v. de Natura 2000gebiedsdoelen sterk afgenomen. Effecten van maatregelen zijn onvoldoende zeker te voorspellen. Een verdere verergering van de situatie in het algemeen en voor toppereend, visdief, zwarte stern en andere viseters dreigt en moet als significant worden gezien (Backes et al. 2011). 


\subsection{Impact additionele sterfte}

De PB past bij de beoordeling van effecten op soorten in het kader van de Flora- en faunawet een stapsgewijze uitsluiting toe van significante effecten per gevolg en per soort. Daarbij kunnen bij elke stap inschattingsfouten worden gemaakt. Sommige soorten vallen al heel vroeg af door een discutabele aanname. Voor de Roerdomp bijvoorbeeld, een soort met een populatieomvang beneden de doelstelling en landelijk een slechte staat van instandhouding en bekend als slachtoffer van windturbines (Klop \& Brenninkmeijer 2014; Hötker et al. 2006), wordt de kans op een significant effect simpel uitgesloten, omdat de kans op risicovolle verplaatsingen en dus aanvaringsslachtoffers zeer klein wordt geacht. "De roerdomp foerageert met name in moerassen en ruigten, doorgaans op maximaal enkele kilometers van het nest (Van der Hut 2001). Het onderzoeksgebied vormt geen geschikt foerageergebied en ligt daarnaast te ver van het broedgebied." Dit houdt geen rekening met verplaatsingen van broedvogels over grote afstanden en over water (Gilbert et al. 2005). Het is onmogelijk in deze contra-expertise alle soorten en aannames langs te lopen. Soorten als bruine kiekendief, zee- en visarend, meeuwen, ganzen en zwanen zijn vaker slachtoffer van windparken dan gedacht (Dürr 2016). Verwacht mag worden dat zeker voor die soorten die in een slechte staat van instandhouding verkeren, extra zorgvuldigheid wordt betracht om aannames te onderbouwen.

De uitsluiting in de PB van een significant effect van additionele sterfte op populatieniveau berust in alle kansrijke gevallen uiteindelijk op de redenatie dat de verliezen kleiner zijn dan $1 \%$ van de natuurlijke sterfte. De 1\%-mortaliteitsnorm is een criterium, inhoudende dat iedere tol van minder dan $1 \%$ van de totale jaarlijkse sterfte van de betrokken populatie moet worden beschouwd als nietsignificant. De 1\%-norm is geen drempel, waarboven per definitie en op voorhand sprake is van een significant negatief effect en vice versa. Het overschrijden van de $1 \%$-norm wordt gehanteerd als 'alarmbel', waarboven het effect dat optreedt nader moet worden geïnterpreteerd. De aanname is dat bij een additionele sterfte van minder dan $1 \%$ van de natuurlijke sterfte er in het geheel geen effect merkbaar is op de populatie. De toepasbaarheid van deze norm als beoordelingskader binnen de Natuurbeschermingswet 1998 is door de Raad van State bevestigd (ABRvS 1 april 2009, 200801465/1/R2).

In de leidraad significantie (LNV) wordt deze 1\%-norm gerechtvaardigd met een beroep op de 'veerkracht' van populaties. Het de vraag of deze rechtvaardiging opgaat in dit IJsselmeersysteem dat, zoals uit de ANT-studie blijkt (Noordhuis et al. 2014), zwaar onder druk staat. Teunissen et al. (2015) concluderen dat in beginsel niet kan worden gesteld dat een populatie voldoende veerkracht heeft als deze in omvang afneemt, zelfs als de verliezen en drempelwaarden goed zijn ingeschat.

Om in te zien dat dit criterium niet altijd gebruikt kan worden, willen we de grutto als voorbeeld aanhalen. De grutto laat al jaren een achteruitgang zien van ongeveer 3\% per jaar sinds de jaren zestig (Sovon vogelbalans 2014) met als gevolg een zeer sterke achteruitgang en grote inkrimping van het verspreidingsgebied, kortom: een ongunstige staat van instandhouding. Onderzoek heeft uitgewezen dat de oorzaken in het broedgebied liggen, dat de overleving van adulte vogels zeer hoog is en de reproductie onvoldoende is om die sterfte te compenseren (o.a. proefschrift Kentie 2015). Dit probleem doet zich voor bij weidevogels in heel Europa (Roodbergen et al. 2012). Het is blijkbaar in de huidige situatie extreem moeilijk om het reproductieresultaat te verbeteren. Voortzetting van de huidige trend leidt uitsterven. De grutto is dus een duidelijk voorbeeld van een soort met onvoldoende veerkracht en elke additionele sterfte zal de tijd tot uitsterven bekorten. Uiteraard is die additionele sterfte dan niet de oorzaak van dat uitsterven, maar voor de beoordeling van de staat van instandhouding en de kans op het halen van gebiedsdoelen is een dergelijke situatie wel belangrijk, zeker als het om een verbeter- of een uitbreidingsdoel gaat.

Ook bij het beoordelen van het effect van sterfte op de haalbaarheid van de populatiedoelstelling wordt in de passende beoordeling dit criterium gebruikt. De beoordeling voor visdief, zwarte stern en dwergmeeuw berust - behalve op de aanname dat de sterfte niet groter is dan $1 \%$ van de natuurlijke sterfte - op de vaststelling dat deze niet groter is dan additionele sterfte bij de kleine mantelmeeuw, die geen gevolgen heeft en lager is de potential biological remove (PBR) naar Wade (1998). Zwarte stern, visdief en dwergmeeuw worden in dit kader vergelijkbaar geacht met de kleine mantelmeeuw. Het betoog dat de populatie van visdief, zwarte stern en dwergmeeuw een grote additionele sterfte 
aankunnen zonder significant effect, net als de kleine mantelmeeuw, overtuigt niet. Dat de gepresenteerde modeluitkomsten voor de kleine mantelmeeuw gunstig zijn, komt door het hoge broedsucces waarmee is gerekend.

De PBR is ontwikkeld voor en toegepast bij populatieverliezen van zeezoogdieren en zeevogels, o.a. door jacht en visserij (o.a. Wade 1998; Niel \& Lebreton; 2005, Robards et al. 2009; Richard \& Abraham, 2013). De methode om het maximale aantal individuen te berekenen dat aan de populatie kan worden onttrokken zonder onaanvaardbare gevolgen voor de populatie lijkt op zichzelf wetenschappelijk goed onderbouwd. Het principe achter de PBR-berekening is dat meer dieren aan een populatie kunnen worden onttrokken naarmate die populatie groter is ( $\mathrm{Nmin}$ ), een groter natuurlijk groeivermogen heeft (Rmax), minder onder druk staat door andere factoren en er over al deze aspecten meer zekerheid bestaat (FR). In Wade (1998) is de berekening van de Potential Biological Removal geformuleerd als:

$\mathrm{PBR}=\mathrm{Nmin} \times 0,5 \mathrm{Rmax} \times \mathrm{FR}$

Waarin:

Nmin = een minimumschatting van de grootte van de populatie,

Rmax $=$ de theoretische of geschatte maximale netto per capita groeisnelheid van de populatie, en

$\mathrm{FR}=$ een 'recovery factor' tussen 0.1 en 1 (in het Faunabeheerplan rf genoemd).

De methode berekent een populatieoverschot en gaat altijd uit van een potentieel groeiende populatie, want uitgangspunt is het maximale reproductievermogen. Voor de berekeningen zou een veilige schatting van de maximale jaarlijks groeisnelheid van de populaties van deze drie soorten zijn aangenomen, maar beter zou zijn geweest de bandbreedte aan te geven. Nu is niet te beoordelen hoe veilig die schatting is. De gebruikte reproductiewaarde voor de visdief bv. is hoger dan die gebruikt door Schippers et al. (2009), maar ligt voor de populatie op de Kreupel in het westelijke IJsselmeer in feite zo laag dat dit heeft geleid tot het beoordelen van de staat van instandhouding als onvoldoende, ondanks het feit de aantallen broedparen voldoen aan het vigerende Natura 2000-doel voor het IJsselmeer (Noordhuis et al. 2014). De PBR is vooral bedoeld om normen te stellen voor de hersteltijd van populaties die op ongeveer de helft van de draagkracht zitten in een leefomgeving met voldoende voedsel en vestigingsmogelijkheden (Robards et al. 2009; Schekkerman \& Koffijberg 2016). Onder die omstandigheden kan de reproductie stijgen en zal er inderdaad een groot reproductieoverschot geproduceerd kunnen worden. De vraag is of de methode ook geëigend is voor het beoordelen van het effect van verliezen op populaties met een doel op ongeveer de draagkracht van het leefgebied en een populatiegrootte daar nog onder. En helemaal de vraag is of de formule wel toegepast kan worden als de Rmax structureel negatief is, zoals in het voorbeeld van de grutto (Teunissen et al. 2015). Volgens Green et al. (2016) is de PBR niet valide voor deze toepassing, want arbitrair, hiervoor niet ontwikkeld en niet gevalideerd.

In het IJsselmeer is de situatie voor de drie genoemde viseters ook zodanig dat getwijfeld kan worden aan de veerkracht van de populaties, er heerst voedselgebrek; de kwaliteit van de habitat is onder de maat. Voor de visdief heeft dat in de meeste jaren geleid tot een zeer laag broedsucces, niet alleen in het IJsselmeer, maar ook in de Waddenzee. Zodanig laag dat de visdiefpopulatie zich in de afgelopen decennia nog altijd niet heeft kunnen herstellen van het dieptepunt in de jaren zestig van de vorig eeuw (o.a. Stienen et al. 2009, 2010; Van der Winden et al. 2013). De berekeningen van de PBR maken helemaal geen gebruik van werkelijk in het gebied gemeten reproductiecijfers. Zou men dat wel doen, dan was er in de meeste jaren geen reproductieoverschot.

De zwarte stern en de dwergmeeuw gebruiken het IJsselmeer als niet-broedvogel om er ruien en/of op te vetten voor de trek. De trend van de zwarte stern in West Europa is negatief (zie paragraaf 2.1). De populatie van de dwergmeeuw in Europa lijkt stabiel, nog niet geheel hersteld van eerdere verliezen (Birdlife International 2004), maar lijkt stijgend in de Nederlandse Noordzeekustzone (Camphuysen 2009). Als het IJsselmeer in combinatie met de Waddenzee de belangrijkste stop over is voor de zwarte stern en het voedselaanbod limiterend dan kan verlies aan leefgebied ook tot extra 
sterfte leiden. Is het voedsel buiten het broedgebied niet limiterend maar juist de reproductie in het broedgebied, dan heeft die additionele sterfte geen effect op het populatieniveau. Indien de reproductie in de broedgebieden slecht is, en er dus te weinig nieuwe rekruten worden geproduceerd, dan kunnen extra verliezen door verlies aan leefgebied in het IJsselmeer tot kostbare verliezen voor deze zwakke populaties leiden en uiteindelijk ook tot een afname van de populatieomvang in het IJsselmeer. Het is dus helemaal niet zeker dat een theoretisch mogelijk reproductieoverschot ook werkelijk aanwezig is en dat extra sterfte vanzelfsprekend kan worden opgevangen door de veerkracht van de populatie. Er is veerkracht als er voldoende broed- en verblijfgebieden zijn voor uitbreiding van de populatie, als er vitale geslachtsrijpe individuen beschikbaar zijn om gedode individuen te vervangen en als er genoeg voedsel is om de maximale reproductie te realiseren. Is dat niet het geval, dan is noch de 1\%-norm (leidraad significantie, 2010), noch de PBR een goed criterium om het bestaan van een effect op het populatieniveau te voorspellen. Een passende beoordeling zou de vitaliteit van een populatie beter kunnen beoordelen op basis van demografische modellen die rekening houden met toevallige ontwikkelingen en die gebruikmaken van reproductie en sterfteparameters bepaald aan de lokale populatie. Voor een willekeurige locatie is dat wellicht een zware eis, maar voor een belangrijk Natura 2000-gebied als het IJsselmeer lijkt dat in lijn met het voorzorgsbeginsel.

Populaties kennen in de tijd doorgaans een logistische groeicurve die eerst snel stijgt, maar dan min of meer stabiliseert rond de draagkracht van het leefgebied. In de praktijk is de draagkracht niet constant en is er altijd wel een deel van het leefgebied of een periode waarin ergens de draagkracht verlaagd en limiterend is. Populaties fluctueren daardoor rond een denkbeeldig evenwicht.

Veranderingen in de omstandigheden verleggen die evenwichten naar boven of naar beneden en de populaties volgen, meestal met een vertraging als gevolg van veerkracht of als gevolg van na-ijling door trage aanpassing. Belangrijk is om vast te stellen dat in een populatie die op of dichtbij draagkracht is, sterfte en reproductie min of meer in evenwicht zijn. In die situatie worden de maximale reproductie en groeisnelheid dus nooit bereikt! De gebiedsdoelen voor het IJsselmeer zijn ongeveer gebaseerd op de draagkracht, want het zijn gemiddelde aantallen over vijf jaren. De PBR is in voor veel doelen van het IJsselmeer dus niet toepasbaar.

Om de effecten van extra sterfte of verlies aan leefgebied op termijn op het populatieniveau te schatten, kan het best gebruikgemaakt worden van dynamische populatiemodellen die rekening houden met toevallige variatie in geboorte en sterfte en met variatie in ruimte en tijd in de geschiktheid van het leefgebied (Verboom et al. 2001, Schippers et al. 2009). Wanneer additionele sterfte, ook als deze klein is, niet wordt gecompenseerd door verminderde verliezen elders, leiden deze onvermijdelijk tot een gemiddeld lager populatieniveau op termijn. Het is dus zaak aannemelijk te maken of aan te tonen dat er voldoende veerkracht in een populatie is en dat extra verliezen worden gecompenseerd alvorens een significant effect op basis van veerkracht uit te sluiten.

Op pagina 114 van de PB wordt geschreven dat "de huidige staat van instandhouding van de soorten wordt bepaald door oorzaken waarop windpark Fryslân geen effect heeft (zoals beschikbaarheid voedsel, klimaatverandering)". Een windpark heeft inderdaad geen direct effect op klimaatverandering, maar kan wel degelijk de staat van instandhouding beïnvloeden door additionele sterfte en verlies aan leefgebied. Klimaatverandering werkt door in de frequentie dat bepaalde soorten het IJsselmeer 'nodig hebben'. Strenge winters kunnen echter nog wel degelijk voorkomen en dus zullen soorten als grote zaagbek en nonnetje ook in de toekomst dit gebied voor overleving in de winter nodig hebben. In het conceptbeheerplan zijn doelen niet naar beneden bijgesteld (mededeling RWS op informatiebijeenkomst in Harderwijk) zoals verwacht wordt in de PB (blz. 98) voor zwarte stern en dwergmeeuw. De instandhoudingsdoelen kunnen overigens ook alleen worden veranderd door het aanwijzingsbesluit aan te passen. Die doelstellingen blijven dus uitgangspunt voor het beheer en voor de beoordeling van ingrepen. In de ANT-studie wordt geconcludeerd dat de neergaande trends vooral in de regio zelf veroorzaakt zijn en dat er maatregelen nodig zijn om de doelen te halen.

Metapopulatiemodellen in plaats van het gebruikte $1 \%$-criterium en de PBR

Voor de visdief lijkt de voedselsituatie in Waddenzee en IJsselmeer structureel slecht (Stienen et al. 2009; Noordhuis et al. 2014) en het is de vraag of additionele sterfte door een hogere reproductie gecompenseerd kan worden. 
Het in de PB gebruikte statische en deterministische model is niet geschikt om de doorwerking van extra sterfte te schatten. Bovendien worden verschillende soorten min of meer vergelijkbaar geacht, terwijl het inschatten van effecten op populatieniveau maatwerk op soortniveau is.

Een betere methode om de effecten op het populatieniveau van additionele sterfte te schatten, is door gebruik te maken van ruimtelijk expliciete, dynamische populatiemodellen die rekening houden met toevallige variatie in geboorte, sterfte en dispersiegedrag, specifiek per soort. Er zijn overeenkomsten tussen genoemde soorten, maar zeker in de reproductiecijfers zullen er belangrijke verschillen zijn, want er zijn grote verschillen tussen deze soorten in de populatietrend. Om de werkelijke effecten in beeld te krijgen, kan er gebruikgemaakt worden van metapopulatiemodellen, die niet alleen de populatie waarvoor een doelstelling is geformuleerd in ogenschouw neemt, maar ook de vestigingen die daarmee een aantoonbare relatie onderhouden. De populatie van de visdief in het IJsselmeer bijvoorbeeld vormt samen met die in de Oostelijke Waddenzee en de Friese Waddenkust één samenhangende netwerkpopulatie of metapopulatie. Aangetoond is dat toen het met de Waddenzeepopulatie slecht ging de IJsselmeerpopulatie groeide (Van Rijn et al. 2010). Samen zijn ze min of meer stabiel, zij het op een historisch te laag niveau (Stienen et al. 2009; Schippers et al. 2009; Schippers et al. 2010). Zolang de voedselsituatie in de Waddenzee en het IJsselmeer slecht is en er sprake is van een lage reproductie (Van der Winden et al. 2009), is de populatieomvang zeer gevoelig voor extra sterfte, doordat een buffer aan niet-broedende vogels ("floaters") laag of afwezig kan zijn. De veerkracht in de populatie lijkt dan ook onvoldoende.

Het voordeel van een metapopulatie-benadering is dat daarin automatisch de externe werking van een ingreep wordt meegenomen en ook de cumulatie van verschillende ingrepen kan worden gemodelleerd. Ook Drewitt \& Langston (2006) pleiten voor de (verdere) ontwikkeling en toepassing van ruimtelijke en dynamische populatiemodellen. Natuurlijk is deze benadering niet op korte termijn haalbaar. Voor de borging van de staat van instandhouding van bedreigede soorten in Natura 2000gebieden zou je eigenlijk op nationaal niveau met populatiemodellen de vinger aan de pols moeten houden. De praktijk om nu slechts op gebiedsniveau de duurzame staat van instandhouding te toetsen, doet geen recht aan de oorspronkelijke doelstelling van de vogelrichtlijn om de staat van instandhouding in de lidstaten en op Europees niveau te verzekeren (Backes et al. 2011). Vooral ook omdat de toetsing van effecten in cumulatie meestal niet veel om het lijf heeft (Broekmeijer \& Sanders, 2013).

\section{Natuurlijke sterfte}

De additionele sterfte als gevolg van windpark Fryslân voor visdief (broedvogel) en zwarte stern (doortrekker/opvetter) is in alle geoptimaliseerde scenario's hoger dan de 1\%-mortaliteitsnorm. Ter beoordeling van de omvang van het effect van het aantal aanvaringslachtoffers van een Natura 2000soort, is $1 \%$ van de gemiddelde jaarlijkse sterfte (ook wel $1 \%$ van de 'natuurlijke mortaliteit') van die soort in het Natura 2000-gebied als eerste beoordelingsgrens aangehouden. De soortspecifieke jaarlijkse "natuurlijke" sterfte (\%) is voor de meeste soorten afgeleid van een website (BTO BirdFacts), maar onduidelijk is in veel gevallen op welk bronnen die gestoeld zijn. Voor de soorten waarvan de jaarlijkse sterfte niet bekend is, is de natuurlijke sterfte van een nauw verwante soort in de berekening toegepast, waarvoor ook geldt dat onduidelijk blijft of dat terecht is. 


\section{Conclusies}

Bij de stapsgewijze uitsluiting van een meer dan incidentele sterfte wordt er, gezien de waargenomen sterfte door windparken, bij een groot aantal soorten te gemakkelijk uitgegaan dat het plangebied niet relevant is voor de soort.

De uitsluiting in de PB van een significant effect van additionele sterfte op populatieniveau berust in alle kansrijke gevallen uiteindelijk, na aanvullende analyses, op de redenatie dat de verliezen kleiner zijn dan $1 \%$ van de natuurlijke sterfte. In de leidraad significantie (LNV) wordt deze $1 \%$-norm gerechtvaardigd met een beroep op de 'veerkracht' van populaties. Het de vraag of deze rechtvaardiging opgaat in dit IJsselmeersysteem dat, zoals uit de ANT-studie blijkt (Noordhuis et al. 2014), zwaar onder druk staat. Ons inziens zou aangetoond moeten worden hoe natuurlijke sterfte en de reproductie respectievelijk af en toe zou kunnen nemen, om de additionele verliezen te compenseren. De berekeningen van de PBR in de PB hebben geen gebruikgemaakt van werkelijk in het (bron)gebied gemeten sterfte- of reproductiecijfers. Zou men dat wel doen, dan was er in de meeste jaren geen reproductieoverschot en geen veerkracht. Als er geen veerkracht is, dan is noch de $1 \%$-norm, noch de PBR een goed criterium om het bestaan van een effect op het populatieniveau te voorspellen. Dit lijkt de juridische consensus ter discussie te stellen, maar de $1 \%$-norm is slechts aanvaardbaar bij gebrek aan een betere wetenschappelijke methode. Met de toepassing van demografische modellen blijkt die er wel degelijk te zijn.

De huidige staat van instandhouding van de soorten wordt in belangrijke mate bepaald door oorzaken waarop windpark Fryslân geen effect heeft zoals beschikbaarheid voedsel, klimaatverandering. Die doelstellingen uit het aanwijzingsbesluit blijven echter wel uitgangspunt voor het beheer en voor de beoordeling van ingrepen. In de ANT-studie wordt geconcludeerd dat de neergaande trends in de regio zelf veroorzaakt zijn en dat er maatregelen nodig zijn om de doelen te halen.

Een betere methode om de effecten op het populatieniveau van additionele sterfte te schatten, is door gebruik te maken van beter onderbouwde aanvarings- en verstoringskansen en van (eventueel zelfs ruimtelijk expliciete) dynamische populatie modellen die rekening houden met toevallige variatie in geboorte, sterfte en dispersiegedrag, specifiek per soort. Zolang de voedselsituatie in de Waddenzee en het IJsselmeer slecht is, is de veerkracht in de populatie visdieven in het IJsselmeer waarschijnlijk onvoldoende.

Het waarschijnlijke gebrek aan draagkracht bij zwarte stern en visdief sluit een significant effect van additionele sterfte, die misschien veel hoger is dan geschat, niet uit. De aanvulling op de PB met een veel lager aantal slachtoffers, gecompenseerd door mitigatie, heeft ons niet overtuigd. 


\section{$2.5 \quad$ Cumulatie}

De PB past een stapsgewijze uitsluiting toe van significante effecten per gevolg en per soort. Daarbij vallen de meeste soorten af, omdat wordt aangenomen dat aanvaringsrisico's en de additionele mortaliteit laag en verwaarloosbaar zijn. Voorbeelden zijn soorten met een slechte staat van instandhouding in het IJsselmeer en in Nederland, zoals roerdomp, bruine kiekendief, porseleinhoen, bontbekplevier, kemphaan en grutto. Voor genoemde soorten, maar ook eenden en steltlopers, wordt het risico op aanvaringen als zo incidenteel beoordeeld dat hieraan in de passende beoordeling verder helemaal geen aandacht wordt besteed. Ze hebben "geen binding met het plangebied" of "geen frequente risicovolle vliegbewegingen". Dit zijn aannames die soms behoorlijk bezijden de werkelijkheid kunnen zijn. Voor een soort als de bruine kiekendief bijvoorbeeld is een zeer kleine aanvaringskans aangenomen, maar uit een monitoringstudie in de Eemshaven blijkt dat deze soort wel degelijk regelmatig slachtoffer kan zijn van aanvaringen met windturbines (Klop \& Brenninkmeijer 2014). Behalve de Natura 2000-doelsoorten zijn er nog legio andere trekvogels en wintergasten die dit belangrijke natuurgebied benutten of doorkruisen: bijvoorbeeld zeearend en visarend. Voor al die soorten wordt maar aangenomen dat een aanvaring een incident is, zonder rekening te houden met de kwetsbaarheid van hun populaties.

\section{Cumulatie op gebiedsniveau}

Het uitsluiten van effecten en verder onderzoek daarnaar is in veel gevallen gebaseerd op aannames. Dit zijn aannames die soms echter behoorlijk bezijden de werkelijkheid kunnen zijn. De conclusie dat een soort geen significant effect ondervindt, al dan niet in cumulatie met andere projecten, leunt zwaar op deze aannames. Het gebrek aan inzicht in de kans op een aanvaring komt door gebrek aan monitoringstudies. Er zijn maar heel weinig monitoringstudies naar de werkelijke effecten van windturbines en een groot deel daarvan is niet openbaar gemaakt. Het is daardoor niet uitgesloten dat de kans op aanvaringen voor een aantal aanvaringsgevoelige soorten, die steeds als incidenteel beoordeeld wordt, optelt tot een groot effect. In cumulatie stapelen deze effecten zich op en kunnen ze wel degelijk te groot zijn. Het is zonder uitgebreid onderzoek niet mogelijk om de juistheid of onjuistheid van alle aannames te toetsen. Deze bewijslast ligt bij de initiatiefnemer. Verderop in deze paragraaf wordt dit probleem bij wijze van voorbeeld uitgewerkt voor de visdief. Dat neemt niet weg dat hetzelfde ook geldt voor andere soorten, zoals zwarte stern, fuut, roerdomp en topper.

De Passende Beoordeling past een stapsgewijze uitsluiting toe van significante effecten als gevolg van verlies van leefgebied en mortaliteit per soort. Daarbij vallen de meeste soorten af, omdat wordt aangenomen dat aanvaringsrisico's en de additionele mortaliteit laag en verwaarloosbaar zijn voor deze soorten. Het selectieproces is in de Passende Beoordeling anders beschreven dan in het besluit over de vergunning Nbw. De laatste tekst is leidraad voor onderstaand betoog.

Bij de stapsgewijze uitsluiting constateren we kwetsbare aannames, waarbij verkeerde gevolgtrekkingen kunnen optreden. Dat geldt vooral voor soorten met een slechte staat van instandhouding en waarvoor het IJsselmeer is aangewezen als Natura2000-gebied (tenminste 11 van de 28 uitgesloten soorten). In de Passende Beoordeling is voor 7 soorten de additionele sterfte geschat en vergeleken met de $1 \%$-norm. Daaronder zijn populaties die zich uitstrekken tot buiten het IJsselmeer, zoals visdief, waardoor er sprake is van een externe werking.

De uiteenlopende argumenten voor uitsluiting van een effectbeoordeling dan wel significante sterfte waarbij vraagtekens geplaatst kunnen worden, zijn "geen binding met het plangebied" (21x) en "geen frequente risicovolle (op rotorhoogte) vliegbewegingen" (7x). Onder "geen binding met het plangebied" vallen o.a. roerdomp, bruine kiekendief, steltlopers als kemphaan en grutto, en eenden zoals bergeend, smient en wilde eend. Dit zijn allemaal vogels van waterrijke of natte milieus waarvan niet uitgesloten kan worden dat ze met enige regelmaat het plangebied oversteken. Dat de kans op aanvaringen moeilijk is in te schatten, hangt samen met een gebrek aan kennis over vliegbewegingen, maar betekent niet automatisch dat die kans verwaarloosbaar klein is. Voor de soorten in de categorie "geen frequente risicovolle vliegbewegingen" geldt eigenlijk min of meer hetzelfde: er is onvoldoende kennis over vliegbewegingen om een substantiële kans op aanvaringen uit te sluiten voor soorten als fuut, brilduiker, nonnetje, grote zaagbek en reuzenstern. 
Voor visdief en zwarte stern zijn wel effectbeoordelingen uitgevoerd, maar daarbij worden eveneens onvoldoende onderbouwde aannames gedaan. Het is bijvoorbeeld niet bekend welk deel van de visdieven die nu ter plaatse van het geplande windpark foerageren tot de broedvogels van de Waddenzee en het IJsselmeer behoort. Dat zal bovendien in de toekomst kunnen veranderen, zeker als visdieven op het werkeiland gaan broeden. Het is bij gebrek aan goed gericht onderzoek naar vliegbewegingen (met bv. zenders) ook onmogelijk om zonder zeer grote onzekerheidsmarges in te schatten hoe groot het aantal slachtoffers onder bijvoorbeeld de zwarte sterns zal zijn. Te gemakkelijk wordt aangenomen dat zwarte sterns, net als visdieven op zee, altijd laag vliegen of dat ze van grote hoogte neerdalen naar de slaapplaats of eerst aan de kust dalen en dan laag blijven vliegen.

Aangenomen wordt dat het aantal slachtoffers bij de dagelijkse grote groepsgewijze verplaatsingen van en naar de slaapplaats veel kleiner zal zijn dan bij de dagelijkse foerageerbewegingen.

Een klein niet significant effect op het leefgebied en een kleine additionele sterfte kunnen samen wel optellen tot een significant effect op het populatieniveau, zeker waar deze afzonderlijke effecten zijn onderschat. Effecten van verlies aan leefgebied worden niet 'opgeteld' bij die van additionele sterfte, terwijl beide wel doorwerken op het populatieniveau.

\section{Cumulatieve sterfte bij visdief}

De visdief heeft in Nederland een ongunstige staat van instandhouding. Het landelijke doel is een populatie van 20.000 paren (Natura 2000-doelendocument, LNV 2006). In de vorige eeuw waren dit er 50.000, met een dieptepunt van 6.500 paren in 1965. Van dat dieptepunt is de soort nog altijd niet hersteld. Wij gaan hier op basis van Van der Jeugd et al. (2014) uit van een jaarlijkse sterfte van $11 \%$. Met de gebruikelijke vermenigvuldigingsmethode (Klop et al. 2014), waarbij aan elk paar één 'floater' is toegekend (een floater is een juveniele of subadulte vogel die nog niet broedt of een adulte vogel die in een seizoen niet tot broeden komt), is de nationale $1 \%$-drempel dan 0,11/100*20.000* $3=66$ slachtoffers. Voor het IJsselmeer wordt dit 0,11/100*3300*3=11 slachtoffers. Voor de Waddenzee komen Klop et al. (2014) op een drempel van 16 individuen. Waddenzee en IJsselmeer samen hebben dus een drempel van 27 slachtoffers. De som van de geschatte sterfte op basis van een worstcasescenario (de maximumschatting) van een aantal windparken rondom IJsselmeer en Waddenzee is 95 slachtoffers (Tabel 2). Het aantal slachtoffers als gevolg van Delfzijl-Noord was oorspronkelijk geschat op 38 (Aanvulling Passende Beoordeling Arcadis), maar is na een populatiedaling bijgesteld tot 10 (Klop et al. 2014). Het maximale geschatte aantal van 67 slachtoffers overschrijdt nog steeds sterk de mortaliteitsdrempel van 27 individuen voor de metapopulatie in de Waddenzee en het IJsselmeer. Hierbij is nog geen rekening gehouden met de vermoedelijke onderschatting van het aantal slachtoffers in Windpark Noordoostpolder.

Tabel 2 Geschatte aantal slachtoffers onder de visdief per jaar voor de populatie in het IJsselmeer en de Waddenzee. Gegevens gebruikt voor schattingen zijn gebaseerd op uitkomsten van een Flux Collision Model, of monitoring van slachtoffers (vaak gecorrigeerd voor karkasdetectie en verwijdering door aaseters), of een expertoordeel.

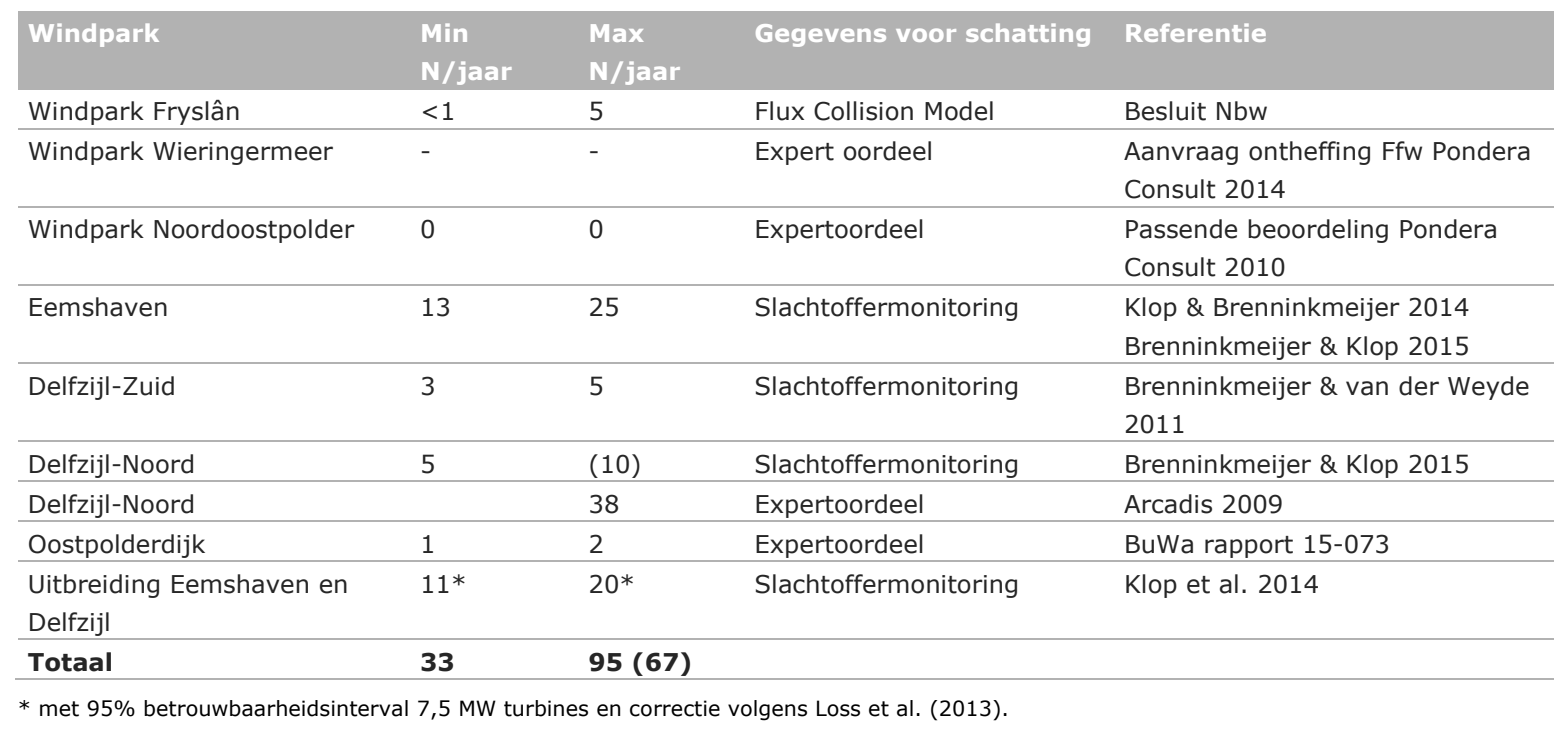


In de eerste Passende Beoordeling voor Windpark Fryslân werd nog rekening gehouden met een sterfte van 50-60 vogels en een verlies van leefgebied door verstoring van 5-10 vogels. Door aan te nemen dat het merendeel van de visdieven beneden de $50 \mathrm{~m}$ vliegt op basis van waarnemingen op de Noordzee, is dit aantal teruggebracht tot maximaal 5 (ontheffing Ffw) en wordt verondersteld dat er ruimte bestaat voor een verlaging van de onderste tiphoogte tot $40 \mathrm{~m}$. Nog afgezien van het feit deze aannames onvoldoende zijn onderbouwd, is de cumulatieve sterfte nu al te hoog om een effect op populatie niveau uit te sluiten.

\section{Soortenbescherming en gunstige staat van instandhouding}

Voor algemene soorten, die in zeer grote aantallen het plangebied passeren (zoals lijsters), worden op jaarbasis per soort een flink aantal vogels slachtoffer van een aanvaring in het (geplande) windpark. Hiervoor kan een ontheffing worden verleend als de maatregel van belang is voor de openbare veiligheid. Voor windpark Fryslân is dit volgens het besluit over de ontheffingsaanvraag het geval. Een andere voorwaarde is dat de sterfte kleiner is dan $1 \%$ van de natuurlijke sterfte. Voor 106 soorten genoemd in het besluit is dat niet gedaan, maar beroept men zich op de vrijstelling volgens artikel $16 \mathrm{ga}$ (algemene maatregel van bestuur, Staatsblad 2015, 324) voor niet-opzettelijk doden. In het advies van de Raad van State betreffende de algemene maatregel van bestuur (wordt) geconstateerd dat onder 'opzettelijk' ook voorwaardelijke opzet valt. Dit houdt in dat iemand willens en wetens de geenszins te verwaarlozen kans aanvaardt dat er dieren worden gedood. Echter, men neemt aan dat het verwachte aantal slachtoffers per diersoort ruim onder het $1 \%$-criterium blijft en dat dit criterium ook bij bestaande windparken en hoogspanningsverbindingen niet wordt overschreden. In het besluit over windpark Fryslân wordt voor tien soorten wél ontheffing gevraagd, omdat de sterftekans onder deze soorten niet uitzonderlijk klein is. Merkwaardigerwijs valt daaronder ook de zanglijster, die ook voorkomt in de lijst van 106 soorten waarvoor vrijstelling zou gelden. Onder de soorten waarvoor ontheffing wordt gevraagd, vallen ook zwarte stern en topper. De visdief staat niet in dit lijstje, wel bij de vrijgestelde soorten, maar wordt in de verdere bespreking wel meegenomen. Voor de tien soorten wordt vastgesteld dat de 1\%-norm niet wordt overschreden en dat ontheffing kan worden verleend.

Het is niet duidelijke waarom:

1. Voor sommige soorten vrijstelling wordt verleend vanwege het uitgangspunt dat het om niet opzettelijk doden gaat;

2. Voor een andere kleine groep van soorten wel ontheffing wordt gevraagd;

3. En waarom een groot aantal soorten helemaal niet genoemd worden in het ontheffingsbesluit, waaronder ook veel soorten met een slechte staat van instandhouding voor het IJsselmeer.

Wanneer de staat van instandhouding op gebiedsniveau is getoetst, is het niet vanzelfsprekend dat de staat van instandhouding op nationaal niveau niet in gevaar is. Bij soorten met een slechte staat van instandhouding in het IJsselmeer en in Nederland kan Windpark Fryslân het bereiken van de gunstige staat van instandhouding bedreigen, zoals bij roerdomp, bruine kiekendief, porseleinhoen, bontbekplevier, kemphaan en grutto. Voor genoemde soorten, maar ook eenden en steltlopers, wordt het risico op aanvaringen als zo incidenteel beoordeeld dat hieraan in de Passende Beoordeling verder helemaal geen aandacht wordt besteed (Tabel 3). Deze soorten kunnen bij een toetsing op soortniveau niet buiten beschouwing blijven. 
Tabel $3 \quad$ Voorbeelden van aangewezen vogelsoorten waarvoor effecten door aanvaring op populatieniveau als gering worden geschat en die daarom niet zijn meegenomen in de Flux Collisionmodelberekeningen voor sterfte (uit: Besluit verlening Natuurbeschermingswetvergunning).

\begin{tabular}{lll} 
Soort & Geen frequente risicovolle vliegbewegingen & Geen binding met het plangebied \\
Fuut & $\mathrm{x}$ & $\mathrm{x}$ \\
\hline Roerdomp & & $\mathrm{x}$ \\
\hline Bruine kiekendief & $\mathrm{x}$ \\
\hline Porseleinhoen & $\mathrm{x}$ \\
\hline Bontbekplevier & $\mathrm{x}$ & \\
\hline Lepelaar & $\mathrm{x}$ & \\
\hline Pijlstaart & $\mathrm{x}$ & \\
\hline Slobeend & $\mathrm{x}$ & \\
\hline Brilduiker & $\mathrm{x}$ & $\mathrm{x}$ \\
\hline Nonnetje & & $\mathrm{x}$ \\
\hline Grote zaagbek & $\mathrm{x}$ \\
\hline Grutto & & $\mathrm{x}$ \\
\hline Kemphaan & & \\
\hline Kluut & & \\
\hline
\end{tabular}

\section{Incidentele slachtoffers}

Voor schaarse soorten die in kleine aantallen het plangebied passeren, zoals roerdomp, bruine kiekendief, visarend en zeearend, zal niet jaarlijks een individu slachtoffer worden van een aanvaring met een windturbine in het windpark en gemiddeld minder dan één slachtoffer per jaar. Voor dergelijke soorten betreft het 'incidentele sterfte', oftewel 'een verwaarloosbaar kleine kans op sterfte als gevolg van het project (ABRS van 8 februari 2012 in zaaknummer. 201100875/1/R2). Het is niet duidelijk of incidentele sterfte nu gelijkgesteld wordt aan 'onopzettelijk doden' en dat daarom automatisch vrijstelling wordt aangenomen. In het aangehaalde advies van de Raad van State staat dat voor opzettelijk handelen ontheffing aangevraagd moet worden met een onderbouwing van de kans op doden. Dat kan onder andere op basis van de binding van een soort met het plangebied en het gedrag van de soort, bijvoorbeeld de ligging van trekroutes en de gebruikelijke vlieghoogte. De kans dat een zeearend het IJsselmeer oversteekt en in aanvaring komt met een van de 89 windmolens is inderdaad niet groot, maar als dat gebeurt, is dat zeker geen te verwaarlozen incident, vooral niet omdat dat ook elders in Nederland kan gebeuren. Voor deze en andere soorten zou beoordeeld moeten worden of ontheffing mogelijk is. Voor heel veel soorten wordt aangenomen dat een aanvaring een incident is, zonder rekening te houden met de kwetsbaarheid van hun populaties en de cumulatie met andere projecten.

Bij de niet-incidentele slachtoffers kan het gaan om trekvogels die geen duidelijke binding hebben met het IJsselmeer en waarbij in de beoordelingen de $1 \%$-norm op basis van de flyway-populatie wordt berekend. Voorbeelden zijn soorten met een slechte staat van instandhouding zoals kuifeend, topper, nonnetje, brilduiker, grote zaagbek, bontbekplevier, goudplevier en kemphaan. Voor deze soorten kan niet worden uitgesloten dat slachtoffers tot de doelpopulatie van het IJsselmeer of de Waddenzee behoren. Verder zijn de populatiegroottes, waar deze de nationale populatie betreffen, over het algemeen nogal hoog ingeschat. Een worstcasebenadering die uitgaat van het voorzorgsprincipe zou de ondergrens van de populatieschatting voor de vogelrichtlijnrapportage (Sovon 2013) aan dienen te houden. Voor de kuifeend zou dit een populatiegrootte van 149.485 i.p.v. 216.000 exemplaren betekenen, voor de topper van 43.327 i.p.v. 80.000 exemplaren en voor nonnetje van 2.639 i.p.v. 6.000 exemplaren. Dit heeft belangrijke gevolgen voor de berekende drempelwaarde voor sterfte.

\section{Soortenbescherming bij bruine kiekendief}

De bruine kiekendief heeft een slechte staat van instandhouding in het IJsselmeer en in Nederland. In de Passende Beoordeling wordt aangenomen dat de soort het IJsselmeer niet oversteekt en dus niet slachtoffer van het windpark kan worden. Het landelijke instandhoudingsdoel is 1300 paren (Profiel document) en wordt niet meer gehaald: er zijn minimaal 1150 paren (bandbreedte: 1150-1250 paren) en er is sprake van een negatieve trend (Sovon 2016). Bij een populatiegrootte van 1150 paren is de 
1\%-drempel bij het jaarlijkse sterftecijfer 0,26 (BTO-facts): 0,26/100*3450 = 9 exemplaren (wederom aannemende dat $30 \%$ van de Nederlandse broedpopulatie uit floaters bestaat). Voor het IJsselmeer berekend zou de maximale sterfte 0,06 exemplaren per jaar zijn; circa eenmaal in de 17 jaar een sterfgeval. Cumulatie van de huidige geschatte sterfte in de omgeving van IJsselmeer en Waddenzee levert al een sterfte op van maximaal 23 individuen per jaar (Tabel 4). Dat wil zeggen ver boven de sterftedrempel van 9 individuen per jaar voor de Nederlandse populatie, waarbij alleen nog maar gegevens van enkele windparken rondom het IJsselmeer en de Waddenzee op een rij gezet zijn. De geschatte en voor een belangrijk deel gemeten sterfte geeft aan dat het noodzakelijk is om beter te onderzoeken wat de kans op aanvaringen is bij kwetsbare soorten als de bruine kiekendief, alvorens een effect op populatieniveau kan worden uitgesloten. Het uitsluiten dat incidentele sterfte als gevolg van windpark Fryslân een negatief effect kan hebben op de instandhoudingsdoelstelling van het Natura 2000-netwerk en op de nationale staat van instandhouding van de bruine kiekendief, is niet terecht. Vermoedelijk is dit bij meer soorten het geval.

Tabel 4 Geschatte aantal slachtoffers onder de bruine kiekendief per jaar voor de populatie in het IJsselmeer en de Waddenzee.

\begin{tabular}{|c|c|c|c|c|}
\hline \multirow[t]{2}{*}{ Windpark } & Min & & \multirow[t]{2}{*}{ Gegevens voor schatting } & \multirow[t]{2}{*}{ Referentie } \\
\hline & N/jaar & N/jaar & & \\
\hline Windpark Fryslân & $<1$ & $<1$ & Expertoordeel & Besluit Nbw \\
\hline Windpark Wieringermeer & & & & Consult 2014 \\
\hline Windpark Zeewolde & $<1$ & 1 & Directe waarnemingen & MER eindconcept \\
\hline \multirow[t]{2}{*}{ Windpark Noordoostpolder } & - & - & Aanname & Passende beoordeling Pondera \\
\hline & & & & Consult 2010 \\
\hline \multirow[t]{2}{*}{ Eemshaven } & 5 & 8 & Slachtoffermonitoring & Klop \& Brenninkmeijer 2014 \\
\hline & & & & Brenninkmeijer \& Klop 2015 \\
\hline Delfzijl-Zuid & 2 & 3 & Slachtoffermonitoring & Brenninkmeijer \& van der Weyde \\
\hline Uitbreiding Eemshaven en & $5 *$ & $10 *$ & Slachtoffermonitoring & Klop et al. 2014 \\
\hline \multicolumn{5}{|l|}{ Delfzijl } \\
\hline Totaal & 12 & 23 & & \\
\hline
\end{tabular}

* met 95\% betrouwbaarheidsinterval 7,5 MW turbines en correctie volgens Loss et al. (2013).

\section{Conclusies}

Significante effecten op de staat van instandhouding van bijvoorbeeld bruine kiekendief en visdief worden ten onrechte uitgesloten. Mogelijk geldt dat voor meer soorten. Het cumulatieve aantal slachtoffers voor de deelpopulatie in Waddenzee en IJsselmeer overschrijdt nu al de 1\%-mortaliteitsdrempel voor de Nederlandse populatie. Het is noodzakelijk om beter te onderzoeken wat de kans op aanvaringen is bij kwetsbare soorten alvorens een effect op populatieniveau uit te sluiten. Nog afgezien van het feit dat de aannames voor de bruine kiekendief, net als voor bijvoorbeeld de zwarte stern, slecht onderbouwd is, is de cumulatieve sterfte nu al te hoog om een effect op populatie niveau uit te sluiten. Voor een groot aantal soorten wordt aangenomen dat een aanvaring een incident is, zonder rekening te houden met de kwetsbaarheid van hun populaties. Het is onmogelijk om al die aannames te weerleggen. In cumulatie zouden de effecten van Windpark Fryslân ook op een aantal andere soorten weleens te groot kunnen zijn voor het verlenen van een ontheffing in het kader van soortbescherming en ook voor een vergunning in het kader van gebiedsbescherming. 


\subsection{Mitigatie}

\section{Natuurvoorziening}

De uitsluitingen van een significant effect van de verliezen aan leefgebied na mitigatie berusten allemaal op het verwachte effect van de natuurvoorziening. Het is de vraag of deze echt leidt tot een toename van de draagkracht voor deze soorten. De natuurvoorziening mitigeert bovendien niet, maar is feitelijk compensatie. Compensatie is pas aan de orde als eventuele alternatieven zijn beoordeeld.

Een nieuw eiland voor de Afsluitdijk met een ondiepe luwe zone zal volgens de PB rustgelegenheid voor verschillende vogelsoorten bieden, inclusief visdief, zwarte stern en dwergmeeuw, wat vooral van belang zou zijn om zo veel mogelijk vogels uit de buurt te houden van het geplande windpark. Dit laatste lijkt niet gegarandeerd. In de aanvulling op de MER wordt meer informatie gegeven over de luwtezone. Deze wordt 25 ha groot, zowel het aanbod en de diversiteit aan vis van het IJsselmeer zullen daardoor toenemen en de functie is foerageer- en rustgebied voor visetende vogels. Er wordt gesteld dat voor de betreffende soorten de rustgelegenheid in het IJsselmeer zal toenemen en daarmee de draagkracht van het gebied. Het is moeilijk voor te stellen dat met een 2 ha-rustgebied en 25 ha-luwtezone de draagkracht van het IJsselmeer voor sterns sterk toe zal nemen; nergens is bewezen dat een gebrek aan rustgebieden limiterend zou zijn voor de aantallen zwarte sterns in het IJsselmeer. Wel behoort met een nieuwe belangrijke rust- en potentiële broedplaats voor sterns in dit deel van het IJsselmeer een verhoogd risico op aanvaring tot de mogelijkheden. De afstand tot het windpark van ruim 4 kilometer kan namelijk in lijnrechte vlucht in ca. 5-10 minuten overbrugd worden door foeragerende sterns (Wakeling \& Hodgson 1992).

\section{Conclusie}

Dat door de aanleg van een vooroever de negatieve effecten van Windpark Fryslân voor alle soorten waarvoor instandhoudingsdoelstellingen zijn gesteld volledig gemitigeerd zijn, lijkt voorbarig. Er vindt een relatief geringe toename van voedselbeschikbaarheid plaats, de belangrijkste factor die populaties zwarte sterns en visdief beperkt. Het is niet zeker of het aanbod aan vliegende vogels in het plangebied - en daarmee de aanvaringskans - niet zal toenemen ten opzichte van de huidige situatie door de creatie van een belangrijk rustgebied in dit deel van het IJsselmeer. 


\subsection{Overige onderwerpen}

Gestuwde trek langs de Afs/uitdijk

In de PB staat te lezen dat aantallen en seizoenspatroon van trekvogels in Den Oever, wat representatief is voor een belangrijk deel van de trek over het plangebied tussen Breezanddijk en Kornwerderzand, ongeveer vergelijkbaar zijn als die op andere locaties in het noordwesten van Nederland (Lensink et al. 2002). Dit zou impliceren dat er overdag weinig of geen stuwing van passerende vogels optreedt. Op grond van de gegevens van de Koninklijke Luchtmacht in oktober 1992 en de resultaten van een telling uitgevoerd in 2002 wordt geconcludeerd dat nachtelijke stuwing langs de Afsluitdijk incidenteel kan optreden, maar bij uitzondering en waarschijnlijk zelfs niet ieder jaar zal geschieden.

Er is onvoldoende rekening gehouden met het feit, dat het waddengebied onderdeel is van "East Atlantic flyway' voor trekvogels. Dit betekent dat grote aantallen van verschillende soorten trekvogels, inclusief soorten waarvoor Nederland een internationale verantwoordelijkheid draagt onder verschillende verdragen (CMS, AEWA), in grote groepen over het gebied trekken. Langs Den Oever op de Afsluitdijk worden bovendien wel degelijk hoge aantallen geteld van soorten die zijn aangewezen als nietbroedvogel in het Natura 2000-gebied IJsselmeer. Zo zijn er dagen in Den Oever waarop een hoog percentage van de landelijke jaartotalen geteld in Nederland worden waargenomen, bijvoorbeeld voor bergeend ( $11 \%$ van het landelijk jaartotaal in 2013 vloog op 6 december 2013 langs den Oever), pijlstaart (13\%) en brilduiker (17\%; Hustings et al. 2014), hoewel onduidelijk is welk deel over de Waddenzee vliegt. Het gaat hier op dergelijke piekdagen om enkele honderden (voor brilduiker) tot duizenden (pijlstaart en bergeend) vogels van deze soorten per dag. In de PB is onvoldoende duidelijk gemaakt wat het "incidentele optreden" van piekaantallen van doortrekkende niet-broedvogels langs de Afsluitdijk voor effecten kan hebben op deze soorten. De conclusie dat sterfte nihil ("neutraal effect") zal zijn zoals voorgesteld voor bovengenoemde en andere soorten in de PB lijkt niet gerechtvaardigd.

\section{Conclusie}

Er wordt in de PB onvoldoende aandacht geschonken aan gestuwde trek van soorten die zijn aangewezen als niet-broedvogel in het Natura 2000-gebied IJsselmeer langs de Afsluitdijk. Op dagen van hoge aantallen passerende trekvogels kan de additionele sterfte voor enkele niet-broedvogels aanzienlijk zijn.

\section{Verlichting en aanvaringen 's nachts}

In Windpark Fryslân wordt een deel van de turbines uitgerust met zogenaamde luchtvaartverlichting boven op de gondel (topverlichting), deze is naar beneden toe afgeschermd, en optioneel ongeveer midden aan de mast (mastverlichting). De verlichting betreft een licht met een voorgeschreven knipperfrequentie dat bij dag wit is en bij nacht rood. De sterkte en spreiding van de verlichting op de turbines is vele malen zwakker dan die van een vuurtoren of een platform op zee. De kans op desoriëntatie van trekkende vogels door de verlichting aan de turbine, waardoor de vogels slachtoffer worden van een aanvaring met de draaiende rotor, wordt minimaal geacht in de PB.

De kans op een aantrekkende werking en aanvaring van trekkende vogels door de verlichting aan de 89 geplande turbines wordt mogelijk onderschat gezien de beschikbare literatuur over aanvaringen bij verlichte windparken en andere hoge structuren door nachtelijke trekvogels (Marques et al. 2014). Al meer dan 100 jaar wordt bij nacht massale vogelsterfte vastgesteld door collisie met verlichte structuren in belangrijke gebieden voor (trek)vogels, op alle continenten en vooral tijdens slecht weer boven open water (review in Heist 2014). Het gaat in dit geval om de totale verlichting aan 89 turbines boven open water, niet een enkele turbine of toren. Door enkele vergelijkende studies zijn bovendien meer slachtoffers vastgesteld door nachtelijke aanvaringen met hoge structuren met knipperende rode lichten typisch voor de luchtvaartverlichting dan structuren met witte verlichting of zonder verlichting (Gauthreaux \& Belser 2006, Gehring et al. 2009; Lundstrom et al. 2013). Door dit niet in de beschouwingen te betrekken, wordt de mortaliteit van trekvogels mogelijk onderschat en dus de kans op mogelijke significante effecten. Op grond hiervan zijn bovendien veel vogelsoorten niet meegenomen in de effectbeoordeling. 


\section{Conclusie}

Er wordt in de PB onvoldoende aandacht geschonken aan additionele sterfte van nachtelijke trekvogels door luchtvaartverlichting op de turbine. Hierdoor wordt de mortaliteit van trekvogels mogelijk onderschat en daarmee de kans op mogelijke significante effecten.

\section{Overige vogelsoorten}

In de passende beoordeling Windpark Fryslân wordt de kans op een significant negatief effect door aanvaringen op populatieniveau voor kwalificerende soorten als roerdomp, wulp, en bruine kiekendief niet voldoende uitgesloten. Dit geldt ook voor soorten als lepelaar en reuzenstern. De distributie en vliegroutes voor deze (mobiele en daarmee kwetsbare) soorten zijn onvoldoende in beeld gebracht in de $\mathrm{PB}$, en daarmee is de kans op aanvaringen onbekend, maar niet automatisch uitgesloten. De roerdomp is een soort met een populatieomvang beneden de doelstelling en een slechte landelijke staat van instandhouding. Roerdompen zijn ook bekend als slachtoffer van wind turbines, ook in gevallen waar dit niet voorspeld was (Klop \& Brenninkmeijer 2014). De soort komt in de PB echter niet aan bod, omdat de kans op risicovolle verplaatsingen en dus aanvaringsslachtoffers zeer klein wordt geacht. Hierbij wordt gewezen op een gebrek aan waarnemingen van roerdompen die het IJsselmeer overvliegen, hoewel onduidelijk is wat hiervoor de telinspanning is geweest. Voor het inschatten van de kans op slachtoffers onder roerdompen, maar ook bv. lepelaars of roofvogels, is gedegen onderzoek naar vliegbewegingen noodzakelijk tijdens de trek, dispersie en tijdens het broedseizoen. Lepelaars betrekken hun voedsel in een straal van 30-40 km rond de kolonie (Bijlsma et al. 2001). Toch wordt ook bij deze soort op voorhand significante effecten van windpark Fryslân uitgesloten. De zeearend is geen doelsoort voor het IJsselmeer, maar gebruikt het plangebied wel (bron: waarneming. $\mathrm{nl}$ ) en is wel bijzonder kwetsbaar voor aanvaringen (Dahl et al. 2013) wat kan leiden tot afname van populaties, door verlaging van het broedsucces, verhoogde mortaliteit, habitatverlies en lokaal uitsterven (Dahl et al. 2012, 2013; May et al. 2013). Het gebrek aan een analyse van aanvaringskansen voor deze soorten is een belangrijke omissie in de PB.

\section{Conclusie}

Effecten op populatieniveau zijn voor kwalificerende soorten als roerdomp, lepelaar, wulp, en bruine kiekendief, maar ook de voor aanvaringen kwetsbare soorten als zeearend en reuzenstern, niet voldoende uitgesloten. 


\subsection{Effecten op vleermuizen}

Uit het Milieueffectrapport Windpark Fryslân (Ten Klooster 2015) blijkt dat verschillende soorten vleermuizen foerageren langs de Afsluitdijk en zich ook in het plangebied bevinden. Het

Milieueffectrapport Windpark Fryslân stelt dat voor de Meervleermuis geldt dat deze in principe laag over het water foerageert op een hoogte tot circa $5 \mathrm{~m}$ en slechts incidenteel op rotorhoogte voorkomt. De Meervleermuis zou dan ook hoogstens incidenteel aanvaringsslachtoffer kunnen zijn ten gevolge van het windpark. Een significant negatief effect op de Meervleermuis wordt derhalve met zekerheid uitgesloten. Heunks et al. (2015) stellen dat de Meervleermuis schaars is, maar wel in het gebied voor komt op verschillende plekken. De Meervleermuis is een soort die laag boven het water vliegt. Tijdens het Nederlandse onderzoek in vijf windparken werden Meervleermuizen regelmatig op grondhoogte vastgesteld, maar werden in het geheel niet of slechts één enkele keer vastgesteld op gondelhoogte. Op grond van geluidsregistraties kan gesteld worden dat de Meervleermuis een zeer lage kans heeft om in aanvaring te komen met windturbines. Dit wordt bevestigd door slachtofferonderzoek. Van de 4.014 gerapporteerde vleermuisaanvarings-slachtoffers in Europa zijn er slechts twee Meervleermuizen.

De Meervleermuis is in heel Europa zeldzaam tot zeer zeldzaam (Haarsma 2011). Zeldzame soorten zoals de Meervleermuis worden zelden gevonden bij windturbines (Ahlén, \& Baagøe 2014). De soort heeft voor zover bekend een lage vlieghoogte, waardoor de soort vaak als "lage risicosoort" wordt geclassificeerd, zoals door Rydell et al. (2010) of Limpens et al. (2007). De gevonden aantallen slachtoffers representeren daarbij echter niet zozeer de kwetsbaarheid van deze soort, maar vooral ook de abundantie van de soort. De dichtheden buiten Nederland zijn te laag om voldoende uitsluitsel te geven of deze soort risico's loopt (Haarsma 2016). Daarnaast is onbekend hoe groot de kans is op aanvaringen voor de soort met turbines op open water. De kans om vleermuizen "off shore" te vinden als slachtoffer is vrijwel 0 , omdat slachtoffers snel zinken, verdwijnen met de stroming of worden gevonden door predatoren (Limpens et al. 2007).

Het onderzoek door Jansen et al. (2013) geeft geen voldoende beeld van de werkelijke aanwezigheid van vleermuizen, omdat dit alleen in de nazomer (14 aug-23 september, drie inventarisaties) heeft plaatsgevonden. Het onderzoek is niet uitgevoerd conform het vleermuisprotocol en heeft zich vooral gericht op de periode in het najaar waarin naar verwachting de meeste slachtoffers vallen. De aanwezigheid van (Meer)vleermuizen in het plangebied en het mogelijke effect op hun foerageergebied zijn daarmee niet onderzocht. De periode van onderzoek spoort wel met de migratieperiode. Uit Scandinavië is bekend dat vleermuizen vanaf de zomer tot herfst foerageren op zee waar prooidieren abundant voorkomen (Ahlén, \& Baagøe 2014). Waarschijnlijk is dit voedselaanbod een belangrijke energiebron gedurende de migratieperiode. Meervleermuizen vliegen met gemak 10 tot $15 \mathrm{~km}$ naar hun voedselgebieden en beslaan hierbij (met de gehele groep) een gebied van ongeveer 350 tot 700 vierkante kilometer (Haarsma 2011). Gezien het ruime aanbod aan dansmuggen boven het IJsselmeer is het niet uit te sluiten dat deze soort wel degelijk gebruikmaakt van het plangebied en is gemist in het ontoereikende onderzoek.

Mogelijke effecten op Meervleermuizen tijdens de migratie naar winterverblijven zijn niet onderzocht. Informatie over de migratieroutes van de Meervleermuis is anekdotisch van aard. Wel is van de Afsluitdijk bekend dat Meervleermuizen deze gebruiken als trekroute en dat de Meervleermuizen vooral in de periode november-maart aanwezig zijn in winterverblijven (Haarsma 2011, 2016). Ahlén et al. (2007) vonden dat Meervleermuizen tot $10 \mathrm{~km}$ uit de kust op zee in grote aantallen voorkwamen. De PB constateert dat er geen verstoring van lokale trekroutes kan optreden door barrièrewerking. In het ontwerp van het windpark is als uitgangspunt een minimum afstand van $600 \mathrm{~m}$ tot de Afsluitdijk aangehouden om verstoring op watervogels te voorkomen die de kustzone van de Afsluitdijk gebruiken als rustgebied. Tot op heden is echter onbekend of er sprake kan zijn van een aantrekkende werking op vleermuizen door windturbines, waardoor migratieroutes kunnen wijzigen en secundaire negatieve effecten kunnen optreden, wanneer vleermuizen hun trekroutes wijzigen (Pelletier et al. 2013). Hierdoor kan sprake zijn van een verhoogde energiebehoefte met mogelijk negatieve effecten op individuen en populaties. Voor Meervleermuizen is dit niet ondenkbaar. Meervleermuizen hebben een hoge binding met lijnvormige elementen (Haarsma 2016). Haarsma adviseert om windturbines minimaal $1 \mathrm{~km}$ uit elkaar te zetten, zodat vleermuizen een rij turbines niet verwarren met een lijnvormig element. 
Bij het oordeel dat er geen significant negatieve effecten kunnen zijn op de Meervleermuis is onvoldoende aandacht geschonken aan de gevolgen van de wijzigingen in de windomstandigheden (zoals turbulenties) rond de Afsluitdijk en de kansen op aanvaringen en barotrauma's. Er is onvoldoende bekend over het jachtgedrag van de Meervleermuis bij windturbines. De soort foerageert vooral op lage hoogte, maar kan (afhankelijk van het prooidieraanbod) ook op tientallen meters hoogte jagen (Ahlén et al. 2007). Limpens et al. (2007) geven een vlieghoogte tijdens de jacht aan van $0.5-2 \mathrm{~m}$ en een vlieghoogte gedurende de trek van $0.5-10 \mathrm{~m}$; de maximale vlieghoogte is onbekend. Over de frequentie waarmee dit "hoogvlieggedrag" plaatsvindt bij windturbines vermeldt de PB niets. Ook over de mogelijk grote verschillen in slachtofferaantallen van vleermuizen tussen turbinelocaties (Rydell et al. 2010; Peste et al. 2015) wordt niets vermeld.

Niet onderzocht is hoe het voedselaanbod verdeeld is op het IJsselmeer en waar de aanleg van een windturbinepark het minste effect zal hebben. Voorafgaand aan de bouw van een windturbinepark is het overigens lastig om vleermuisactiviteit rondom de turbines te voorspellen (Ahlén, \& Baagøe 2014). $\mathrm{Bij}$ goede weersomstandigheden kunnen turbines grote aantallen insecten aantrekken en vleermuizen zijn in staat om dit prooidieraanbod te ontdekken en benutten, zelfs als dit ver buiten hun reguliere leefgebied ligt (Schuster et al. 2015; Pelletier et al. 2013). Hoewel de meeste moderne windturbines zeer hoog zijn (mast- of ashoogte van $80 \mathrm{~m}$ of meer), maakt ca. $20 \%$ van het aantal slachtoffers deel uit van de groep 'laagvliegende soorten' (Haarsma 2016). Monitoring van het populatieverloop van Meervleermuizen vindt in Nederland alleen in de winter plaats. Het aantal dieren dat gemonitord kan worden, ongeveer $5 \%$ van de Nederlandse populatie, is onvoldoende om nauwkeurige uitspraken te doen over een landelijke populatietrend (Haarsma 2011; Haarsma et al. 2016). Populaties vleermuizen zijn vooral gevoelig voor additionele mortaliteit (Voigt et al. 2012; Haarsma 2016). Enkele slachtoffers kunnen dus een groot effect hebben op (lokale) populaties. Op basis van de beschikbare informatie is het onzeker of en zo ja hoeveel impact het turbinepark zou kunnen hebben op de (lokale) gunstige staat van instandhouding.

De aanname dat significante negatieve effecten kunnen worden uitgesloten op basis van een beperkte onderzoeksperiode en de veronderstelde lage vlieghoogte van Meervleermuizen lijkt daarmee onvoldoende onderbouwd. De aanname dat laagvliegende soorten geen slachtoffer worden van hoge turbines is daarom aanvechtbaar en onduidelijk is wat het effect van het verlies van enkele dieren per jaar betekent voor de gunstige staat van instandhouding. Voor een lokale populatie becijfert Haarsma (2011) dat bij een ingreep waardoor jaarlijks 10\% van de populatie verdwijnt door niet-natuurlijke sterfte, de populatie uitsterft na 20-30 jaar.

Volgens Milieueffectrapport Windpark Fryslân (Ten Klooster 2015) is alleen gecumuleerd met een aantal projecten voor de soorten topper, dwergmeeuw, visdief en zwarte stern. Cumulatieve effecten op vleermuizen zijn niet meegenomen. Voor het Windpark Wieringermeer becijfert Haarsma (2016) dat met stilstandvoorziening ('s nachts, bij windsnelheden lager dan $5 \mathrm{~m} / \mathrm{s}$, temperaturen hoger dan $10^{\circ} \mathrm{C}$, droog weer en in de periode begin mei - eind oktober) het aantal slachtoffers zal verminderen, maar dat $40 \%$ van de passerende Ruige dwergvleermuizen slachtoffer wordt (400 dieren/jaar op tienduizenden migranten). Doordat deze soort een lage reproductiesnelheid heeft (gemiddeld $70 \%$ van de wijfjes krijgt 1 jong/jaar), leidt dit, volgens Haarsma, al snel tot negatieve effecten op de gunstige staat van instandhouding. Voor Ruige dwergvleermuizen zou overigens de schaal waarop cumulatieve effecten worden meegenomen vele male groter moeten zijn dan gebruikelijk in een passende beoordeling, waarbij zelfs effecten in het buitenland meegenomen zouden moeten worden. Sterfte tijdens de trek van migrerende (Ruige dwerg)vleermuizen bij windturbines in Duitsland en Nederland heeft mogelijk effect op de wijfjes die overwinteren in Scandinavië en Oost-Europa (Voigt et al. 2012; Dienst Regelingen 2011; Lehnert et al. 2014). Ook voor de Meervleermuis kan cumulatie een rol spelen. Cumulatieve effecten van meerdere windturbineparken kunnen, afhankelijk van de additionele sterfte, dus wel degelijk een rol spelen (zie ook de volgende paragraaf).

Meest talrijke soort in het plangebied was de Ruige dwergvleermuis ( $90 \%$ vd registraties; Heunks et al. 2015). Zij stellen m.b.t. de gunstige staat van instandhouding van de Ruige dwergvleermuis dat uitgaande van een populatie van 50.000-100.000 dieren de jaarlijkse natuurlijke sterfte kan worden geschat op minimaal circa 16.500 dieren (gebaseerd op een jaarlijkse natuurlijke sterfte van 32-34\%, en uitgaande van een populatie van 50.000 dieren). Afhankelijk van de variant bedraagt de 
additionele sterfte als gevolg van windpark Fryslân maximaal 70-150 dieren uitgaande van gemiddeld 1,5 slachtoffer per turbine. Voor variant 3 bedraagt de additionele sterfte (70 slachtoffers), naar schatting maximaal $0,4 \%$ van de gemiddelde natuurlijke sterfte. Op dezelfde wijze kan voor variant 1 en 4 (beide 100 slachtoffers) geschat worden dat de additionele sterfte maximaal 0,6\% van de gemiddelde natuurlijke sterfte bedraagt. Voor variant 2 wordt de additionele sterfte als gevolg van Windpark Fryslân ten slotte geschat op maximaal 0,9\%. Op grond hiervan wordt aangenomen dat de additionele sterfte van de varianten als een verwaarloosbaar effect op de populaties is te beschouwen, zeker wanneer aangenomen wordt dat de huidige populatieomvang van de ruige dwergvleermuis waarschijnlijk groter is dan 50.000 dieren. Een effect op de gehele migrerende populatie wordt hiermee uitgesloten.

Onduidelijk is waar het gemiddelde van (0-3) 1,5 slachtoffer/turbine/jaar aan wordt ontleend door Heunks et al. (2015). Onduidelijk is ook hoe betrouwbaar de jaarlijkse natuurlijke sterfte van 32-34\% is; het artikel m.b.t. de overlevingskansen van Schmidt (1994) was niet te achterhalen. Vrijwel alle studies die overlevingskansen inschatten, maken gebruik van de verkeerde statistische technieken en de technieken die gebruikt worden, beïnvloeden vaak de overlevingskansen van vleermuizen (O'Shea et al. 2014). Overigens is het onjuist om een algemeen gemiddeld sterftepercentage te gebruiken, omdat sterftekansen verschillen afhankelijk van geslacht en leeftijd. De berekening die wordt gemaakt, geeft een zeer grove indicatie van mogelijk additionele sterfte, maar is gevoelig voor de gebruikte waardes. Uitgaande van Haarsma (2016) bedraagt de sterfte in de Wieringermeer bij 100 windturbines 400 dieren/jaar (NB Met stilstandvoorziening). Mortaliteitscijfers variëren sterk tussen locaties en zijn afhankelijk van veel factoren, zoals de topografie en weersomstandigheden (Rydell et al. 2010; Limpens et al. 2013). Per jaar worden door Rydell et al. 0-26 turbineslachtoffers per turbine/jaar gemeld, Limpens et al. (2013) berekenen 14-18 slachtoffers in 54 dagen bij 25 turbines. Een modelmatige benadering, rekening houdend met $0 . a$. topografische factoren en weersomstandigheden, leverde in deze studie onvoldoende precieze informatie op voor de Nederlandse situatie. Afhankelijk van de parametrisatie betekent dat voor 89 turbines de additionele sterfte dus sterk kan variëren (Tabel 5).

Tabel $5 \quad$ Voorbeelden van berekende additionele sterfte voor de Ruige dwergvleermuis op basis van het gemiddeld aantal slachtoffers/turbine/jaar.

\begin{tabular}{lllllll} 
Npop & sterfte & Nsterfte Nturbines avg slachtoffer/turb/jr & Totale sterfte windpark Fryslân additioneel\% \\
\hline 50000 & 0.32 & 16000 & 89 & 0 & 0 & 0.0 \\
\hline 50000 & 0.32 & 16000 & 89 & 1.5 & 133.5 & 0.8 \\
\hline 50000 & 0.34 & 17000 & 89 & 2 & 178 & 356 \\
\hline 50000 & 0.34 & 17000 & 89 & 4 & 2314 & 2.1 \\
\hline 50000 & 0.34 & 17000 & 89 & 26 & 13.6 & \\
\hline
\end{tabular}

De analyse van Heunks et al. (2015) is dus onvolledig, geeft geen gevoeligheidsanalyse voor de gebruikte parameterwaardes en richt zich alleen op sterfte. Deze benadering is ongeschikt om mogelijke effecten in te schatten op het (lokale) populatieniveau. De gunstige staat van instandhouding kan immers alleen beoordeeld worden indien het effect op de (lokale) populatie bekend is. Hiertoe dient een analyse gedaan te worden die zowel sterfte (leeftijd en geslacht specifiek) als aanwas meeneemt in een (meta)populatiedynamisch model, dat rekening houdt met jaarlijkse variatie in overleving en aanwas (O'Shea et al. 2011). Nauwkeuriger data m.b.t. de (lokale) populatiegrootte is daarbij van groot belang om te schatten wat de impact op de sterfte is op de (meta)populatie (Pelletier et al. 2013). Sterfte door infectieziektes en parasitaire belasting, waardoor de fitness van individuen vermindert, spelen een belangrijke rol, waarbij prevalenties periodiek kunnen verschillen (Mühldorfer et al. 2011). Tevens dienen cumulatieve effecten te worden meegenomen (metapopulatiemodel), waarbij ook rekening wordt gehouden met de cumulatieve effecten in de gehele migratiezone van de wijfjes die buiten Nederland overwinteren (Dienst Regelingen 2011; Voigt et al. 2012). Voor de Nederlandse populatie kan additionele mortaliteit door meerdere windparken, binnen en buiten Nederland, zelfs wanneer het $1 \%$ - criterium op één locatie niet wordt gehaald, optellen tot percentages die hier ver boven liggen. 


\section{Conclusies}

Het onderzoek geeft een onvoldoende beeld van de aanwezigheid van vleermuizen, omdat dit alleen in de nazomer heeft plaatsgevonden. De aanwezigheid van (meer)vleermuizen in het plangebied en het mogelijke effect op hun foerageergebied zijn daarmee niet onderzocht. Informatie over de migratieroutes van de meervleermuis is anekdotisch van aard. Mogelijke effecten op meervleermuizen tijdens de migratie naar winterverblijven zijn onvoldoende onderzocht.

$\mathrm{Er}$ is onvoldoende bekend over het "hoogvlieggedrag" van meervleermuizen bij turbines en de kans op aanvaringen en barotrauma "off-shore". Ook is onvoldoende bekend over de aantrekkende werking door turbines, waardoor secundaire negatieve effecten kunnen optreden. De monitoring van meervleermuizen in Nederland is onvoldoende om nauwkeurige uitspraken te doen over een landelijke populatietrend. Op basis van de beschikbare informatie is het daarmee onzeker of en zo ja hoeveel impact het turbinepark zou kunnen hebben op de (lokale) gunstige staat van instandhouding. De aanname dat significante negatieve effecten kunnen worden uitgesloten op meervleermuizen lijkt daarmee onvoldoende onderbouwd.

Cumulatieve effecten op vleermuizen zijn ten onrechte niet meegenomen in de passende beoordeling. Cumulatieve effecten van meerdere windturbineparken kunnen, afhankelijk van de additionele sterfte, een rol spelen. Voor de Nederlandse populatie kan additionele mortaliteit door meerdere windparken, binnen en buiten Nederland, zelfs wanneer het 1\%-criterium op één locatie niet wordt gehaald, optellen tot percentages die hier ver boven liggen.

T.a.v. de Flora- en faunawet is de analyse m.b.t. additionele sterfte van ruige dwergvleermuizen door turbines onvolledig. Mortaliteitscijfers bij turbines variëren sterk tussen locaties en zijn afhankelijk van veel factoren, zoals de topografie en weersomstandigheden. Er wordt ten onrechte geen gevoeligheidsanalyse gedaan voor de gebruikte parameterwaardes, terwijl een eerste aanzet in deze rapportage laat zien dat de additionele sterfte tussen de 0 en $14 \%$ kan liggen. De conclusie dat de additionele sterfte onder de $1 \%$ blijft, is daarmee twijfelachtig. 


\subsection{Effecten op vissen en amfibieën}

In de passende beoordeling wordt gesteld dat "met uitzondering van de rivierdonderpad zijn geen instandhoudingsdoelstellingen gesteld voor vissen. Vissen zijn echter een belangrijke bron van voedsel voor verschillende watervogelsoorten waarvoor wel instandhoudingsdoelstellingen zijn gesteld. Negatieve effecten op vissen kunnen derhalve een indirect negatief effect op viseters hebben".

\section{Effecten op rivierdonderpad}

In het aanwijzingsbesluit Natura 2000-gebied IJsselmeer staat de volgende doelstelling voor de rivierdonderpad (H1163): "doel behoud omvang en kwaliteit leefgebied voor behoud populatie". In de daarbij behorende toelichting staat dat er binnen het IJsselmeer veel waarnemingen van rivierdonderpadden bekend zijn en dat de soort in de afgelopen decennia sterk is toegenomen. Dit is echter enigszins achterhaald, want met de aanleg van het Main-Donau kanaal (geopend op 25 september 1992) is het Donau-stroomgebied verbonden met het Rijn-stroomgebied met als gevolg dat er veel exotische grondels, zoals de Kesslers grondel, marmergrondel, pontische stroomgrondel en zwartbekgrondel het Nederlandse watersysteem binnendringen (Spikmans et al. 2010). Deze soorten concurreren met de rivierdonderpadden om voedsel, schuilplaatsen en ei-afzetplaatsen. Ook staan rivierdonderpadden op het menu van Kesslers grondels en zwartbekgrondels. Op de grote rivieren wordt dan ook al een achteruitgang geconstateerd van rivierdonderpadden en in hoeverre dit ook al op grotere schaal bezig is in het IJsselmeer, is vooralsnog niet duidelijk, maar dat het gaande is, is evident. In dat licht bezien zou moeten worden gekeken of de aanleg van Windpark Fryslân, het areaal, niet bijdraagt aan een (verdere) afname van het areaal [in deze expliciet niet "bestand", want het gaat om eventuele afname van verspreiding (range) i.r.t. de landelijke Staat van Instandhouding, onderdeel 'range'] van de rivierdonderpad binnen het IJsselmeer. Als het verspreidingsareaal binnen Natura2000-gebied IJsselmeer afneemt, dan komt de behoudsdoelstelling voor de rivierdonderpad in gevaar. Indien dit het geval is, dan draagt dit bij tot de afname van de zogeheten Favourable Reference Range (FRR). Naast de parameter Favourable Reference Population (FRP) rapporteert Nederland elke zes jaar de status aan de Europese Unie in Brussel (Ottburg en Van Swaay, 2014). In de passende beoordeling wordt niet ingegaan op de mogelijke effecten van de windturbines in relatie tot de FRR(verspreidingsbeeld) van de rivierdonderpad in het IJsselmeer.

Mogelijke afname van leefgebied of doorvoer functie voor zeeprik en zalm Van de riviertrekvissen fint, rivierprik, zalm en zeeprik (alle bijlage II-soorten van de Europese Habitatrichtlijn), die zich allemaal voortplanten in zoet water, maar het grootste deel van hun leven verblijven in zout water, is bekend dat deze vaste migratiebanen volgen. Deze banen zijn conform de voorschriften van de Europese Commissie opgenomen in de Favourable Reference Range, waarbij geldt dat alleen de uurhokken in het zoete water worden meegenomen (Ottburg en Van Swaay, 2014). Daarnaast geldt voor zeeprik en zalm dat Nederland een doorvoerfunctie heeft en volwassen dieren ongestoord vanuit het zoute water de paaigronden in het naburig gelegen België, Frankrijk en Duitsland te bereiken. Vice versa geldt dit voor de juveniele dieren. De toekomstige vismigratierivier zal hiertoe een bijdrage leveren. In de passende beoordeling is geen blijk gegeven of er wel of niet een mogelijke afname van leefgebied is en/of de doorvoerfunctie voor de soorten als zeeprik en zalm wel of niet in het geding komt tijdens de realisatiefase en de uiteindelijke eindfase van het windturbine park. De geplande vismigratierivier zal naar verwachting een positieve bijdrage leveren voor de genoemde vissoorten.

\section{Effect van geluid op vissen}

In de passende beoordeling wordt gesteld: "Potentiële effecten beperken zich tot onderwatergeluid dat optreedt bij de aanlegwerkzaamheden en van de windturbines in bedrijf. Het ruimtebeslag ten gevolge van de windturbines en de natuurvoorziening is verwaarloosbaar klein ten opzicht van de oppervlakte van het IJsselmeer en heeft geen effect op de vispopulaties." De passende beoordeling meldt echter ook: "Uit het onderzoek naar onderwatergeluid (bijlage 3D) komt naar voren dat het niet geheel is uitgesloten dat geluidsniveaus tijdens heiwerkzaamheden optreden met schadelijke effecten voor vissen als gevolg. Alleen het geluidsniveau van het heien zou tot relevant effect op vissen kunnen leiden. Voor de overige bronnen van geluid, zoals scheepvaart, zijn de geluidsniveaus lager en/of vergelijkbaar met reeds aanwezige geluidsbronnen in de vorm van scheepvaart en worden geen relevante effecten verwacht." 
Vissen hebben twee sensorische systemen ontwikkeld: 1) het zijlijn-orgaan voor het waarnemen van deeltjesbewegingen op zeer korte afstand, ongeveer een- à tweemaal de lichaamslengte en reageert op bewegingen van de vis en beweging van het water en 2) het gehoororgaan. Dit kan veranderingen in waterdruk en signalen over langere afstanden waarnemen. Bij vissen wordt een onderscheid gemaakt tussen hoorgeneralisten en hoorspecialisten. Bij deze laatste groep wordt door een mechanische koppeling tussen zwemblaas of een ander luchtgevulde holte en het binnenoor het geluid versterkt. Hoorspecialisten zijn gevoelig voor geluiden met een frequentie tussen de 50 en $500 \mathrm{~Hz}$. De hoorspecialisten zijn over het hele frequentiebereik gevoeliger voor geluid dan hoorgeneralisten. Twee derde van alle voorkomende zoetwatervissen behoort tot de hoorspecialisten (Van Opzeeland 2007).

Een goed overzicht van effecten van geluid op vissen wordt gegeven in het rapport Vissen en geluidsoverlast - effect van geluidsbelasting onder water op zoetwatervissen (Van Opzeeland, 2007). Verschillende aspecten uit deze studie worden hier aangehaald. Effecten kunnen worden onderverdeeld in de volgende twee typen: (1) impulsgeluiden van zeer korte duur met een hoge frequentie en (2) langdurige of continue geluiden met een matige geluidsintensiteit.

\section{Impulsgeluiden}

Impulsgeluiden ontstaan als gevolg van explosies, sonar, impactcontact (zoals heiwerkzaamheden) of seismisch onderzoek. Dit type geluiden kan ernstige fysiologische schade veroorzaken bij vissen. Een intern rapport van Caltrans (Caltrans 2001) beschrijft de effecten van heiwerkzaamheden op gekooide vissen, geplaatst op verschillende afstanden van de heipaal. Binnen een straal van 50 meter rondom de paal werd korte tijd na de heiwerkzaamheden vissterfte geconstateerd. Vissen vertoonden inwendige bloedingen, verkleuring van de lever en beschadigingen aan de zwemblaas. Caltrans onderzocht voor dit rapport alleen het aantal dode vissen en vermeldt niets over het aantal vissen dat bleef leven met in- of uitwendige beschadigingen. In verschillende andere rapporten achten de auteurs het echter waarschijnlijk dat de zone waarin verwondingen, tijdelijke of permanente (gehoor)beschadigingen kunnen optreden bij vissen zich uitstrekt tot $1000 \mathrm{~m}$ van de heipaal (Hastings en Popper, 2005; Thomsen et al., 2006; Bijnsdorp 2005). Heiwerkzaamheden leverden daarentegen een lage sterfte op bij vislarven van drie soorten (tong, zeebaars en haring). In het lab zijn de larven blootgesteld aan heigeluiden en is de overleving zeven dagen (tong) en tien dagen (zeebaars en haring) gemonitord. Voor deze drie vissoorten zijn significante verschillen in mortaliteit waargenomen, maar de sterfte was over het algemeen laag binnen de periode van die studie (Bolle et al. 2014).

Heiwerkzaamheden onder water produceren relatief laagfrequente impulsgeluiden met zeer hoge geluidsniveaus. Onderzoek aan vissen die experimenteel werden blootgesteld aan dergelijke signalen heeft uitgewezen dat de hoge geluidsniveaus bij lage frequentie leiden tot beschadigingen van nieren, lever en zwemblaas en gasontwikkeling in de ogen en bloedvaten van vissen veroorzaken, wat kan leiden tot embolie en het barsten van de bloedvaten (Sakaguchi et al. 1976; Sverdrup et al. 1994.; Turnpenny et al. 1994; Turnpenny en Nedwell, 1994; Crum en Mao, 2006; Gisiner, 1998; Hirst en Rodhouse, 2000). Vissen met een zwemblaas of luchtgevulde holte blijken door de drukgolven van dit type geluidsbronnen eerder beschadigd te raken dan vissen zonder zwemblaas of luchtgevulde holte (Ermine 1973). Gedetailleerde gegevens met betrekking tot de afstand waarover het geluid van heiwerkzaamheden vissen kan beschadigen of beïnvloeden, ontbreken echter tot dusver (Van Opzeeland, 2007).

Impulsgeluiden, zoals heiwerkzaamheden, kunnen ook hormonale stressreacties veroorzaken bij vissen. Uit onderzoek blijkt kort na het toedienen van impulsgeluiden een toename in afscheiding van het stresshormoon cortisol (Sverdrup et al. 1994; Santulli et al. 1999). Stress bij vissen kan resulteren in verminderde groei en weerstand tegen ziekten (Popper en Carlson, 1998). Daarnaast kan stress het reproductieproces negatief beïnvloeden (Popper en Carlson 1998; Donaldson 1990) en leiden tot verhoogde mortaliteit (Rice, 1990).

\section{Continue geluiden}

Een voorbeeld van een continu geluid onder water zijn motoren van de scheepvaart (vergelijk het met de geluiden van de snelweg op het land), die een verminderde gehoorgevoeligheid kan veroorzaken bij gehoorspecialisten. De continue aanwezigheid van achtergrondgeluid van matige intensiteit kan bovendien geluiden die van belang zijn voor vissen overstemmen (Brumm en Slabbekoorn, 2005). 
Vooral de temporele structuur van signalen, die voor vissen de meeste informatie bevat, blijkt in de aanwezigheid van continu achtergrondgeluid algauw niet meer te kunnen worden waargenomen door vissen (Wysocki en Ladich, 2005). Dit waarnemen is van belang als het gaat om oriëntatie in de omgeving. Langdurig continu aanwezige achtergrondgeluiden kunnen ook tot hormonale stressreacties leiden (zie eerder beschreven). In een onderzoek waarin karpers, riviergrondels en baarzen werden blootgesteld aan geluidsopnames van scheepsmotoren (Wysocki et al. 2006), toonden aan dat zowel hoorspecialisten als hoorgeneralisten een verhoogde afgifte van het stresshormoon cortisol hadden (zie hiervoor de eerder beschreven effecten). In hoeverre gerealiseerde windturbines, een veld met ruim tachtig windturbines, een resonerend effect hebben onder water en wat hiervan de mogelijke effecten zijn op vissen, is niet precies bekend.

Hetgeen hierboven beschreven is m.b.t. impuls- en continugeluiden maakt inzichtelijk dat de in de passende beoordeling opgenomen zinsnede "Alleen het geluidsniveau van het heien zou tot relevant effect op vissen kunnen leiden" geen rechtdoet aan de situatie. Het is aannemelijk om te veronderstellen dat zowel in de realisatiefase van een aantal jaren (impulsgeluiden bij heiwerkzaamheden) als wel in de uiteindelijke opleveringsfase (aanwezige continu geluiden) effecten op vissen zijn te verwachten. Aan de andere kant kunnen windturbines een positief effect hebben op de lokale visstand na realisatie door het creëren van nieuw habitat (bv. Andersson en Öhman 2010). Wat het gecombineerde effect van vissterfte en eventueel toegenomen vishabitat voor gevolgen heeft voor de vispopulaties van het IJsselmeer op de langere termijn, na realisatie, is in dit stadium moeilijk te voorspellen.

In dat licht bezien kan men spreken van een handeling in en nabij een Natura2000-gebied die valt onder voorwaardelijke opzet en dus is het voorzorgsprincipe uit de Flora- en faunawet van toepassing.

\section{Conclusies}

In de PB wordt niet ingegaan op de mogelijke effecten van de windturbines op het verspreidingsbeeld van de rivierdonderpad in het IJsselmeer. In de PB is verder geen blijk gegeven of er wel of niet een mogelijke afname van leefgebied is of de doorvoerfunctie voor zeeprik en zalm wel of niet in het geding komt tijdens de realisatiefase en de uiteindelijke eindfase van het windturbinepark. Het is tot slot aannemelijk om te veronderstellen dat zowel in de realisatiefase (impulsgeluiden bij heiwerkzaamheden) als tijdens de uiteindelijke opleveringsfase (aanwezige continu geluiden) effecten door geluid op vissen zijn te verwachten, hoewel de impact van het windpark op de vispopulaties in het IJsselmeer op de langere termijn onduidelijk zijn. 


\section{Literatuur}

Aarts, B. \& L. Bruinzeel, 2009. De nationale windmolenrisicokaart voor vogels. Sovon-notitie 09-105, Sovon Vogelonderzoek Nederland, Ubbergen, Altenburg \& Wymenga, Feanwalden

Ahlén, I., L. Bach, H.J. Baagøe \& J. Pettersson, 2007. Bats and offshore wind turbines studied in southern Scandinavia. Report 5571, Swedish Environmental Protection Agency.

Ahlén, I. \& H.J. Baagøe, 2014. Bat diversity and wind power - investigations required for risk assessment in Denmark and Sweden. Conference on Wind power and Environmental impacts (CWE2013) in Stockholm, February 5-7 2013

Andersson, M.H. and Öhman, M.C., 2010. Fish and sessile assemblages associated with wind-turbine constructions in the Baltic Sea. Marine and Freshwater Research, 61(6), pp.642-650.

Backes, C.W., M.P. van Veen, B.A. Beijen, A.A. Freriks, D.C.J. van der Hoek, A.L. Gerritsen, 2011. Natura 2000 in Nederland. Juridische ruimte, natuurdoelen en beheerplanprocessen. Planbureau voor de leefomgeving (PBL), Den Haag.

Band, W., Madders, M. \& Whitfield, D.P., 2005. Developing field and analytical methods to assess avian collision risk at wind farms. In De Lucas, M. Janss, G. \& Ferrer, M., eds. Birds and Wind Power: Barcelona: Lynx Edicions.

Becker, P.H. and Ludwigs, J.D., 2004. Sterna hirundo Common tern. BWP Update, 6, 91-137.kt?

Bijlsma, R.G., Bakker, S., van Galen, T., Kleefstra, R., Mulder, J. and de Vries, C., 2007. Broedende roofvogels op het Friese vasteland: verspreiding, talrijkheid, trend en voedselkeus. De takkeling, 15(1), pp.48-72.

Blums, P., Mednis, A., Bauga, I., Nichols, J.D. and Hines, J.E., 1996. Age-specific survival and philopatry in three species of European ducks: a long-term study. Condor, pp.61-74.

Bolle, L.J., C.A.F. de Jong, E. Blom, P.W. Wessels, C.J.G. van Damme en H.V. Winter, 2014. Effect of pile-driving sound on the survival of fish larvae. Imares-report C182/14. Imares Wageningen UR, IJmuiden. 33p.

Brenninkmeijer, A., \& C. van der Weyde, 2011. Monitoring vogelaanvaringen Windpark Delfzijl-Zuid 2006-2011, A\&W rapport 1656. Altenburg \& Wymenga ecologisch onderzoek, Feanwâlden.

Brenninkmeijer, A. \& E. Klop, 2015. Aanvullende ecologische beoordeling windenergie Groningen. Effecten op Visdief en Noordse stern. A\&W-rapport 2120. Altenburg \& Wymenga ecologisch onderzoek, Feanwâlden.

Brenninkmeijer, A. \& E. Klop, 2015. Monitoring aanvaringsslachtoffers twee nieuwe turbines in Windpark Eemshaven 2012-2014. A\&W-rapport 2023. Altenburg \& Wymenga ecologisch onderzoek, Feanwâlden.

Broekmeijer, M. \& M. Sanders, 2013. Cumulatietoets bij Natura 2000 kan beter. Landschap 2: 95-101.

Brumm, H. and H. Slabbekoorn, 2005. Acoustic communication in noise. Advances in the Study of Behavior 35: 151-209.

Caltrans, 2001. Pile installation demonstration project, fisheries impact assessment. PIDPEA 012081 Caltrans Con-tract 04A0-148. San Francisco, Oakland bay bridge east span seismic safety project.

Camphuysen, C.J., 2009. Het gebruik van zeetrektellingen bij de analyse van populatieschommelingen. (2) Dwergmeeuwen Larus minutus langs de Nederlandse kust. Sula 22: 49-66. 
Chamberlain, D.E., Rehfisch, M.R., Fox, A.D., Desholm, M. and Anthony, S.J., 2006. The effect of avoidance rates on bird mortality predictions made by wind turbine collision risk models. Ibis, 148(s1), pp.198-202.

Collier, M.P. \& M.J.M. Poot, 2014. Review and guidance on use of "shutdown-on-demand" for wind turbines to conserve migrating soaring birds in the Rift Valley/Red Sea Flyway. Rapport 13-282. Bureau Waardenburg, Culemborg.

Crum, L.A. and Y. Mao, 2006. Acoustically enhanced bubble growth at low frequencies and its implications for human diver and marine mammal safety. Journal of the Acoustical Society of America, 99, 2898-2907.

Dahl, E.L., Bevanger, K., Nygård, T., Røskaft, E. and Stokke, B.G., 2012. Reduced breeding success in white-tailed eagles at Smøla windfarm, western Norway, is caused by mortality and displacement. Biological Conservation,145(1), pp.79-85.

Dahl, E.L., May, R., Hoel, P.L., Bevanger, K., Pedersen, H.C., Røskaft, E. and Stokke, B.G., 2013. White-tailed eagles (Haliaeetus albicilla) at the Smøla wind-power plant, Central Norway, lack behavioral flight responses to wind turbines. Wildlife Society Bulletin, 37(1), pp.66-74.

De Lucas, M., Ferrer, M., Bechard, M.J. and Muñoz, A.R., 2012. Griffon vulture mortality at wind farms in southern Spain: Distribution of fatalities and active mitigation measures. Biological Conservation, 147(1), pp.184-189.

Dienst Regelingen Ministerie van Economische Zaken, Landbouw en Innovatie 2011. Soortenstandaard Ruige dwergvleermuis Pipistrellus nathusii.

Dirksen, S., Schekkerman, H., Winden, J. van der, Poot, M.J.M., Lensink, R., Bergh, L.M.J. van den \& Spaans, A.L., 1998. Slaaptrek van zwarte sterns en visdieven in de omgeving van de windturbine op de sluizen van Den Oever. Rapportnr. 98.057, Bureau Waardenburg, Culemborg / Instituut voor Bos- en Natuuronderzoek (IBN-DLO), Wageningen.

Dirksen, S., K. Krijgsveld \& R. Fijn, 2009. Offshore windenergie: effecten op vogels. De levende Natuur, 110: nummer 6, pag. 284-286.

Donaldson, E.M., 1990. Reproductive indices as measures of the effect of environmental stressors in fish. American Fisheries Society Symposium, 8, 109-122.

Drewitt, A.L. \& R.H.W. Langston, 2006. Assessing the impacts of wind farms on birds. British Ornithologists' Union Ibis, 148, 29-42.

Dürr, Tobias, 2016. http://www.Ifu.brandenburg.de. Vogelverluste an windenergieanlagen.

Ermine, C.A., 1973. The effects of underwater explosions on swimbladder fish. Defense Technical Information center, Accession Number: AD0767019.

Everaert, J. and Stienen, E.W., 2007. Impact of wind turbines on birds in Zeebrugge (Belgium). Biodiversity and Conservation, 16(12), pp.3345-3359.

Everaert, J., 2003. Wind turbines and birds in Flanders: Preliminary study results and recommendations.

Everaert, J., 2003. Windturbines en vogels in Vlaanderen: voorlopige onderzoeksresultaten en aanbevelingen. Natuurpunt.

Everaert, J., 2008. Effecten van windturbines op de fauna in Vlaanderen. Onderzoeksresultaten, discussie en aanbevelingen. Rapporten van het Instituut voor Natuur- en Bosonderzoek 2008 (rapportnr. INBO.R.2008.44). Instituut voor Natuur- en Bosonderzoek, Brussel.

Ferrer, M., de Lucas, M., Janss, G.F., Casado, E., Munoz, A.R., Bechard, M.J. and Calabuig, C.P., 2012. Weak relationship between risk assessment studies and recorded mortality in wind farms. Journal of Applied Ecology, 49(1), pp.38-46. 
Fijn, R.C., K.L. Krijgsveld, H.A.M. Prinsen, W. Tijsen \& S. Dirksen, 2007. Effecten op zwanen en ganzen van het ECN windturbine testpark in de Wieringermeer. Aanvaringsrisico's en verstoring van foeragerende vogels. Rapport 07-094. Bureau Waardenburg, Culemborg.

Fox, A.D., Desholm, M., Kahlert, J., Christensen, T.K. and Krag Petersen, I.B., 2006. Information needs to support environmental impact assessment of the effects of European marine offshore wind farms on birds. Ibis, 148(s1), pp.129-144.

Gauthreaux, S.A. \& C.G. Belser, 2006. Effects of artificial night lighting on migrating birds. In Ecologicial Consequences of Artificial Night Lighting. C. Rich \& T. Longcore, Eds.: 67-93. Island Press. Washington, DC.

Gauthreaux, S.A. Jr \& Belser, 1999. The behavioral responses of migrating birds to different lighting systems on tall towers. In: Transcripts of Proceedings of Conference on Avian Mortality at Communication Towers, 119th meeting of the American Ornithologists' Union. Ithaca, NY: Cornell University Press. Zie: www.towerhill.com/workshop/proceedings/html/pan4.html

Gehring, J., Kerlinger, P. and Manville, A.M., 2009. Communication towers, lights, and birds: successful methods of reducing the frequency of avian collisions. Ecological Applications, 19(2), pp. 505-514.

Gisiner, R.C., 1998. Proceedings - workshop on the effects of anthropogenic noise in the marine environment. Marine Mammal science Program, Office of Naval research.

Green, R.E., R.H.W. Langston, A. McCluskie, R. Sutherland \& J.D. Wilson, 2016. Lack of sound science in assessing wind farm impacts on seabirds. Journal of Applied Ecology, 1-7.

Haarsma, A.J., 2011. De Meervleermuis in Nederland. Rapport nr. 2011.40. Zoogdiervereniging, Nijmegen.

Haarsma, A.J., 2016. Omgaan met effecten van windturbines op vleermuizen. De Levende Natuur 117(1): 11-15.

Haarsma, A.J., H. Limpens \& K. Spoelstra. Meervleermuis Myotis dasycneme. In: S. Broekhuizen, K. Spoelstra, J.B.M. Thissen, K.J. Canters \& J.C. Buys (redactie). De Nederlandse Zoogdieren. Natuur van Nederland 12. Naturalis Biodiversity Center \& EIS Kenniscentrum Insecten en andere ongewervelden, Leiden: 191-194.

Hastings, M.C. and A.N. Popper, 2005. Effects of sound on fish. California Dep. of Transportation contract 43A0139 Task Order, 1.1-82.

Heist, K.W., 2014. Assessing bat and bird fatality risk at wind farm sites using acoustic detectors (Doctoral dissertation, University of Minnesota).

Heunks et al., 2015. Effecten van Windpark Fryslân op vogels, vleermuizen en overige beschermde natuurwaarden.

Hirst, A.G. and P.G. Rodhouse, 2000. Impacts of geophysical seismic surveying on fishing success. Reviews in fish Biology and Fisheries, 10, 113.

Hötker, H., K.-M. Thomsen \& H. Köster, 2006. Impacts on biodiversity of exploitation of renewable energy sources: the example of birds and bats. Facts, gaps in knowledge, demands for further research, and ornithological guidelines for the development of renewable energy exploitation. Michael-Otto-Institut im NABU, Bergenhusen.

Hüppop, O., Dierschke, J., EXO, K.M., Fredrich, E. and Hill, R., 2006. Bird migration studies and potential collision risk with offshore wind turbines. Ibis, 148(s1), pp.90-109.

Hustings, F., Troost, G. \& Boele, A., 2014. Trektellingen in Nederland in 2013 (Jaarverslag Trektellen.nl). Trektellen.nl/Sovon Vogelonderzoek Nederland, Nijmegen.

Jansen et al., 2013. Vleermuizen Markermeer en IJsselmeer. Veldinventarisatie 2012 in zoekgebieden voor windenergie. 
Jensen, A.C., Collins, K.J., Lockwood, A.P.M., Mallinson, J.J. \& Turnpenny, W.H. 1994. Colonisation and fishery potential of a coal-ash artificial reef, Poole Bay, United Kingdom. Bull. Mar. Sci. 55: 1263-1276.

Karman, C.C., B. Winters \& H.P.M. Schobben, 1995. Slaaptrek van zwarte sterns langs de kust van Wieringen. RWS-DF. 8 p.

Kentie, R., 2015. Spatial demography of black-tailed godwits. Metapopulation dynamics in a fragmented agricultural landscape. Proefschrift Rijksuniversiteit Groningen.

Kleyheeg-Hartman, J.C., B. Engels, C. Heunks, A. Gyimesi \& M.P. Collier, 2015. Zwarte sterns en visdieven in het plangebied van Windpark Fryslân. Resultaten van veldonderzoek naar vliegintensiteit en -gedrag in de nazomer van 2015. Bureau Waardenburg Rapportnr. 15-214. Bureau Waardenburg, Culemborg.

Klop, E. \& A. Brenninkmeijer, 2014. Monitoring aanvaringsslachtoffers Windpark Eemshaven 20092014, Eindrapportage vijf jaar monitoring. A\&W-rapport 1975. Altenburg \& Wymenga ecologisch onderzoek, Feanwâlden.

Klop, E., A. Brenninkmeijer \& E. van der Heijden, 2014. Ecologische beoordeling uitbreiding opgave windenergie provincie Groningen. A\&W-rapport 2020. Altenburg \& Wymenga ecologisch onderzoek, Feanwâlden.

Krijgsveld, K.L., Akershoek, K., Schenk, F., Dijk, F. and Dirksen, S., 2009. Collision risk of birds with modern large wind turbines. Ardea, 97(3), pp.357-366.

Krijgsveld, K.L., Fijn, R.C., Heunks, C., Van Horssen, P.W., De Fouw, J., Collier, M., Poot, M.J.M., Beuker, D. and Dirksen, S., 2011. Effect studies offshore wind farm Egmond aan Zee. Flux, flight altitude and behaviour of flying birds. Bureau Waardenburg report, pp.10-219.

Lehnert, L.S., Kramer-Schadt, S., Schönborn, S., Lindecke, O., Niermann, I. et al., 2014. Wind Farm Facilities in Germany Kill Noctule Bats from Near and Far. PLoS ONE 9(8): e103106. doi:10.1371/journal.pone.0103106

Lensink, R., H. van Gasteren, F. Hustings, L.S. Buurma, G. van Duin, L. Linnartz, F. Vogelzang \& C. Witkamp, 2002. Vogeltrek over Nederland 1976-1993. Schuyt \& Co, Haarlem.

Leopold, M., van Bemmelen, R.S.A. \& Geelhoed, S.C.V., 2011. Zeevogels op de Noordzee. Achtergronddocument bij Natuurverkenning 2011. Werkdocument 257, Wettelijke Onderzoekstaken Natuur \& Milieu, Wageningen.

Leopold, M.F., R.S.A. van Bemmelen \& A.F. Zuur, 2013. Responses of Local Birds to the Offshore Wind Farms PAWP and OWEZ off the Dutch mainland coast. Imares. Report number C151/12, Texel.

Limpens, H.J.G.A., H. Huitema \& J.J.A. Dekker, 2007. Vleermuizen en windenergie, Analyse van effecten en verplichtingen in het spanningsveld tussen vleermuizen en windenergie, vanuit de ecologische en wettelijke invalshoek. VZZ rapport 2006.50. Zoogdiervereniging VZZ, Arnhem, in opdracht van SenterNovem.

Limpens, H.J.G.A., M. Boonman, F. Korner-Nievergelt, E.A. Jansen, M. van der Valk, M.J.J. La Haye, S. Dirksen \& S.J. Vreugdenhil, 2013. Wind turbines and bats in the Netherlands - Measuring and predicting. Report 2013.12, Zoogdiervereniging \& Bureau Waardenburg

LNV, Ministerie van, 2009. Besluit Natura 2000-gebied IJsselmeer. Ministerie van Landbouw, Natuur en Voedselveiligheid, Den Haag

LNV, Ministerie van, 2010. Leidraad significantie. Ministerie van Landbouw, Natuur en Voedselveiligheid, Den Haag.

Longcore, T., Rich, C., Mineau, P., MacDonald, B., Bert, D.G., Sullivan, L.M., Mutrie, E., Gauthreaux, S.A., Avery, M.L., Crawford, R.L. and Manville, A.M., 2013. Avian mortality at communication towers in the United States and Canada: which species, how many, and where?. Biological Conservation, 158, pp.410-419. 
Lundstrom, L.A., Horn, D.J. and Capparella, A.P., 2013. The effects of tower structure and weather conditions on avian mortality at three television towers in central Illinois. Illinois State Academy of Science. Transactions, 106, p.9.

Manville, A.M., 2000. The ABCs of avoiding bird collisions at communication towers: the next steps. In Proceedings of the Avian Interactions Workshop, December 2, 1999. Charleston, US: Electric Power. Research Institute. Zie: migratorybirds.fws.gov/issues/towers/abcs.html

Marques, A.T., Batalha, H., Rodrigues, S., Costa, H., Pereira, M.J.R., Fonseca, C., Mascarenhas, M. and Bernardino, J., 2014. Understanding bird collisions at wind farms: an updated review on the causes and possible mitigation strategies. Biological Conservation, 179, pp.40-52.

May, R., Hamre, Ø., Vang, R. and Nygård, T., 2012. Evaluation of the DTBird video-system at the Smøla wind-power plant. Detection Capabilities for Capturing Near-turbine Avian Behaviour. NINA Report, 910.

May, R., Hoel, P.L., Langston, R., Dahl, E.L., Bevanger, K., Reitan, O., Nygård, T., Pedersen, H.C., Røskaft, E. and Stokke, B.G., 2010. Collision risk in white-tailed eagles. NINA Rapport 639: 25 pp. Norsk institutt for naturforskning, Trondheim., 639.

May, R., Nygård, T., Dahl, E.L. and Bevanger, K., 2013. Habitat utilization in white-tailed eagles (Haliaeetus albicilla) and the displacement impact of the Smøla wind-power plant. Wildlife Society Bulletin, 37(1), pp.75-83.

Mühldorfer, K., Speck, S., Kurth, A., Lesnik, R., Freuling, C. et al., 2011. Diseases and Causes of Death in European Bats: Dynamics in Disease Susceptibility and Infection Rates. PLoS ONE 6(12): e29773. doi:10.1371/journal.pone.0029773

Niel, C. \& J-D Lebreton, 2005. Using Demographic Invariants to Detect Overharvested Bird Populations from Incomplete Data. Conservation Biology, 19:826-835

Noordhuis, R., S. Groot, M.D. Pires \& M. Maarse, 2014. Wetenschappelijk eindadvies ANTIJsselmeergebied. Vijf jaar studie naar kansen voor het ecosystem van het IJsselmeer, Markermeer en IJmeer met het oog op de Natura-2000 doelen.

O'Shea, T.J., L.E. Ellison \& T.R. Stanley, 2011. Adult survival and population growth rate in Colorado big brown bats (Eptesicus fuscus). Journal of Mammalogy, 92(2):433-443.

O'Shea, T.J., L.E. Ellison \& T.R. Stanley, 2014. Survival Estimation in Bats: Historical Overview, Critical Appraisal, and Suggestions for New Approaches. Ch15: 297-336.

Ottburg, F.G.W.A. en C.A.M. van Swaay (red., 2014). Gunstige referentiewaarden voor populatieomvang en verspreidingsgebied van soorten van bijlage II, IV en V van de Habitatrichtlijn. Wageningen, Wettelijke Onderzoekstaken Natuur \& Milieu, WOt-werkdocument 124. 269 blz. 12 tab.; diverse ref.

Pearce-Higgins, J.W., L. Stephen, R.H.W. Langston, I.P. Bainbridge \& R. Bullman, 2009. The distribution of breeding birds around upland wind farms. Journal of Applied Ecology 46: 1323-1331.

Pelletier, S.K., K.S. Omland, K.S. Watrous \& T.S. Peterson 2013. Information synthesis on the potential for bat interactions with offshore wind facilities. Final Report. U.S. Dept of the Interior, Bureau of Ocean Energy Management, Headquarters, Herndon, VA. OCS Study BOEM 2013-01163.

Peste, F., A. Paula, L.P. da Silva, J. Bernardino, P. Pereira, M. Mascarenhas, H. Costa, J. Vieira, C. Bastos, C. Fonseca \& M.J. Ramos-Pereira, 2015. How to mitigate impacts of wind farms on bats? A review of potential conservation measures in the European context. Environmental Impact Assessment Review 51:10-22

Poot, M.J.M., J. de Jong \& C. Heunks, 2014. Totale populatieomvang en verspreiding van dwergmeeuwen tijdens de voorjaarspiek in april 2014 in het IJsselmeergebied. Resultaten van vliegtuigtellingen op basis van Distance sampling \& analysis. Rapport 14-140. Bureau Waardenburg, Culemborg. 
Poot, M.J.M., J. de Jong, R-J. Jonkvorst, R.C. Fijn \& C. Heunks, 2012. Watervogels op het open water in de winter in het IJsselmeergebied in januari en maart 2012. Resultaten van vliegtuigtellingen op basis van Distance sampling \& analysis. Rapport 12-085. Bureau Waardenburg, Culemborg.

Poot, M.J.M., S. Lilipaly, P. Wolf, A. van Kleunen \& T.J. Boudewijn, 1999. Atlas vogelconcentraties en vliegbewegingen Delta. Aanvullend veldwerk Kuifeend, Tafeleend, Brilduiker, Middelste zaagbek en Aalscholver. Rapport 99.85. Bureau Waardenburg bv, Culemborg.

Popper, A.N. and T.J. Carlson, 1998. Application of sound and other stimuli to control fish behavior. Transactions of the American Fisheries Society, 127, 673-707.

Prinsen, H.A.M., C. Heunks, J. van der Winden \& P.W. van Horssen, 2009. Effecten van vijf windparken op vogels langs de dijken van de Noordoostpolder. Effectbeoordeling ten behoeve van het MER Windparken Noordoostpolder. Rapport 09-090. Bureau Waardenburg, Culemborg.

Prinsen, H.A.M., J.C Hartman, D. Beuker \& L.S.A. Anema, 2013. Vliegbewegingen van meeuwen en sterns bij twee windparken op de Eerste Maasvlakte. Veldonderzoek naar flux, vlieghoogtes en aanvaringsslachtoffers. Rapport 13-023. Bureau Waardenburg, Culemborg.

Rice, J.A., 1990. Bioenergetics modelling approaches to evaluation of stress in fishes. American Fisheries Society Symposium, 8, 80-92.

Richard, Y. \& E.R. Abraham, 2013. Application of Potential Biological Removal methods to seabird populations. New Zealand Aquatic Environment and Biodiversity Report No. 108. Ministry for Primary Industries.

Rijkswaterstaat, Ministerie voor Infrastructuur en Milieu, 2015. Passende Boordeling Afsluitdijk.

Robards, Martin D., John J. Burns, Chanda L. Meek, Annette Watson, 2009. Limitations of an optimum sustainable population or potential biological removal approach for conserving marine mammals: Pacific walrus case study. Journal of Environmental Management 91: 57-66.

Roodbergen, M., B. van der Werf \& H. Hötker, 2012. Revealing the contributions of reproduction and survival to the Europe-wide decline in meadow birds: review and meta-analysis. Journal für die Ornithologie, 153: 53-74.

Rydell, J., L. Bach, M.J. Dubourg-Savage, M. Green, L. Rodrigues \& A. Hedenström, 2010. Bat mortality at wind turbines in northwestern Europe. Acta Chiropterologica, 12(2): 261-274.

Sakaguchi, S., O. Fukuhara, S. Umezawa, M. Fujiya and T. Ogawa, 1976. The influence of underwater explosions on fishes. Bull. Nansei Reg. Fish. Res. Laboratory, 9, 33-65.

Santulli, A., A. Modica, C. Messina, L. Ceffa, A. Curatolo, G. Rivas, G. Fabi and V. D'Amelio, 1999. Biochemical responses of European Sea Bass (Dicentrarchus labrax L.) to the stress induced by off shore experimental seismic prospecting. Marine Pollution Bulletin, 38, 1105-1114.

Schekkerman, H. \& K. Koffijberg, 2016. Evaluatie van de berekening van 'toelaatbaar afschot' in het faunabeheerplan Smient Zuid-Holland 2014-2019. Nota: Sovon Nijmegen.

Schippers, P., Snep, R.P.H., Schotman, A.G.M., Jochem, R., Stienen, E.W.M. \& Slim, P.A., 2009. Seabird metapopulations: searching for alternative breeding habitats. Population Ecology 51 (4): 459-470.

Schippers, P., Stienen, E.W.M., Schotman, A.G.M., Snep, R.P.H. \& Slim, P.A., 2011. The consequences of being colonial: Allee effects in metapopulations of seabirds. Ecological Modelling 222 (30613070).

Schobben, H.P.M., 1999. Slaaptrek van zwarte sterns. Meerkoet 1999(4): 21-23.

Schobben, H.P.M., 2001. Slaaptrek zwarte stern: 2000. Meerkoet 2001(2): 7-9.

Schobben, H.P.M., 2004. Verslag slaaptrektellingen van de zwarte stern 2003. Meerkoet 2004(1): 9-11. 
Schuster, E., Bulling, L. and Köppel, J., 2015. Consolidating the state of knowledge: A synoptical review of wind energy's wildlife effects. Environmental management, 56(2), pp.300-331.

Shuster, E., L. Bulling \& J. Köppe, 2015. Consolidating the State of Knowledge: A Synoptical Review of Wind Energy's Wildlife Effects. Environmental Management 56:300-331

Spikmans, F.N. van Kessel, M. Dorenbosch, J. Kranenbarg, J. Bosveld \& R. Leuven, 2010. Plaag Risico Analyses van tien exotische vissoorten in Nederland. Nederlands Centrum voor Natuuronderzoek: Stichting RAVON, Radboud Universiteit Nijmegen, Stichting Bargerveen \& Natuurbalans - Limes Divergens, Nijmegen.

Stienen, E.W.M., A. Brenninkmeijer \& J. van Winden, 2009. De achteruitgang van de Visdief in de Nederlandse Waddenzee. Exodus of langzame teloorgang? Limosa 82: 171-186.

Still, D., Little, B. \& Lawrence, S., 1996. The Effects of Wind Turbines on the Bird Population at Blyth Harbour. DTI contract ETSU W/13/00394/REPORT.

Sverdrup, A., P.G. Kruger and K.B. Helle, 1994. Role of endothelium in regulation of vacular functions in two teleosts. Acta Physiologica Scandinavica, 152, 219-233.

Teunissen, W., C. Kampichler, M. Roodbergen \& R. Vogel, 2015. Beoordeling van de staat van instandhouding van de Kievit (Ljip) Vanellus vanellus als broedvogel in de provincie Fryslân. Sovonrapport 2015/56. Sovon Vogelonderzoek Nederland, Nijmegen.

Thomsen, F., K. Ludemann, R. Kafermann and W. Piper, 2006. Effects of offshore windfarm noise on marine mammals and fish. Biola. Hamburg, Germany on behalf of COWRIE Ltd., 1-62.

Turnpenny, A.W.H. and J.R. Nedwell, 1994. The effect on marine fish, diving mammals and birds of underwater sound generated by seismic surveys. Consultancy Report FCR 089/94, Fawley Aquatic research Laboratories Ltd.

Turnpenny, A.W.H., K.P. Thatcher and J.R. Nedwell, 1994. The effects of fish and other marine animals of high level underwater sound. FRR 127/94, Fawley Aquatic research Laboratories, Ltd. Southampton, UK.

Van Bemmelen, R.S.A., Leopold, M.F., Geelhoed, S.C.V., Verdaat, H. \& Bravo Rebolledo, E., 2013. Futen in de Hollandse Noordzeekustzone in december 2012 en januari 2013. IMARES rapport c030/13.

Van der Winden, J., K.L. Krijgsveld, H. Inberg \& R.C. Fijn, 2008. Beschermingsplan Duin- en Kustvogels. Basis rapport deel A. Bureau Waardenburg, Culemborg.

Van der Winden, J., Dirksen, S., Gyimesi, A. and Poot, M.J.M., 2009. Broedsucces en voedsel van visdieven op de Kreupel 2011-2012. Voortgangsrapport met overzicht van, 2012.

Van Opzeeland, I., H. Slabbekoorn, T. Andringa, C. ten Cate, 2007. VissEn geluidsoverlast - Effect van geluidsbelasting onder water op zoetwatervissen. Rijksuniversiteit Groningen en Universiteit Leiden.

Van Rijn, S. 2005. Watervogels in het IJsselmeer en Markermeer: seizoensverslag 2004/2005.

Van Rijn, S., M. Menken \& M. Platteeuw, 2010. Doeluitwerking Natura 2000 IJsselmeergebied. Uitwerking van Natura 2000-doelen in omvang, ruimte en tijd. Delta Project management in opdracht van Rijkswaterstaat-Waterdienst, Lelystad.

van Roomen, M., Hornman, M., Flink, S., Langendoen, T., van Winden, E., Nagy, S. \& van Turnhout, C. 2012. Flyway-trends for waterbird species important in Lakes IJsselmeer and Markermeer. Sovon-rapport 2012/22, Sovon Vogelonderzoek Nederland, Nijmegen.

van Roomen, M., Stahl, J., Schekkerman, H., van Turnhout, C. \& Vogel, R.L., 2013. Advies ten behoeve van het opstellen van een monitoringplan voor vogels in het Nederlandse Noordzeegebied. Sovonrapport 2013/22. Sovon Vogelonderzoek Nederland, Nijmegen. 
van Roomen, M.W.J., Boele, A., van der Weide, M.J.T., van Winden, E.A.J. \& Zoetebier, D., 2000. Belangrijke vogelgebieden in Nederland, 1993-97. Actueel overzicht van Europese vogelwaarden in aangewezen en aan te wijzen speciale beschermingszones en andere belangrijke gebieden. SOVONinformatierapport 2000/01. SOVON Vogelonderzoek Nederland, Beek-Ubbergen.

Verbeek, R.G., D. Beuker, J.C. Hartman \& K.L. Krijgsveld, 2012. Monitoring vogels Windpark Sabinapolder. Onderzoek naar aanvaringsslachtoffers. Rapport 11-189. Bureau Waardenburg, Culemborg.

Voigt, C., A.G. Popa-Lisseanu, I. Niemann \& S. Kramer-Schadt, 2012. The catchment area of wind farms for European bats: A plea for international regulations. Biological Conservation 153: 80-86

Wade, P.R., 1998. Calculating limits to the allowable human-caused mortality of Cetaceans and Pinnipeds. Marine Mammal Science 14(1): 1-37.

Wakeling, J.M. and Hodgson, J., 1992. SHORT COMMUNICATION OPTIMISATION OF THE FLIGHT SPEED OF THE LITTLE, COMMON AND SANDWICH TERN. Journal of experimental biology, 169(1), pp.261-266.

Winkelman, J.E., 1992a. De invloed van de Sep-proefwindcentrale te Oosterbierum (Fr.) op vogels. 1. Aanvaringsslachtoffers. RIN-rapp. 92/2. IBN-DLO, Arnhem.

Winkelman, J.E., 1992b. De invloed van de Sep-proefwindcentrale te Oosterbierum (Fr.) op vogels. 2. Nachtelijke aanvaringskansen. RIN-rapp. 92/3. IBN-DLO, Arnhem.

Winkelman, J.E., 1992c. De invloed van de Sep-proefwindcentrale te Oosterbierum (Fr.) op vogels. 4. Verstoring. RIN-rapp. 92/5. IBN-DLO, Arnhem.

Wysocki, L.E. and F. Ladich, 2005. Hearing in fishes under noise conditions. Journal of the association for research in Otolaryngology, 6, 28-36.

Wysocki, L.E., J.P. Dittami and F. Ladich, 2006. Ship noise and cortisol secretion in European freshwater fishes. Biological Conservation, 128, 501-508. 
Wageningen Environmental Research Postbus 47

6700 AA Wageningen

T 0317480700

www.wur.nl/environmental-research

Wageningen Environmental Research

Rapport 2774

ISSN 1566-7197
De missie van Wageningen University \& Research is 'To explore the potential of nature to improve the quality of life'. Binnen Wageningen University \& Research bundelen Wageningen University en gespecialiseerde onderzoeksinstituten van Stichting Wageningen Research hun krachten om bij te dragen aan de oplossing van belangrijke vragen in het domein van gezonde voeding en leefomgeving. Met ongeveer 30 vestigingen, 5.000 medewerkers en 10.000 studenten behoort Wageningen University \& Research wereldwijd tot de aansprekende kennisinstellingen binnen haar domein. De integrale benadering van de vraagstukken en de samenwerking tussen verschillende disciplines vormen het hart van de unieke Wageningen aanpak. 



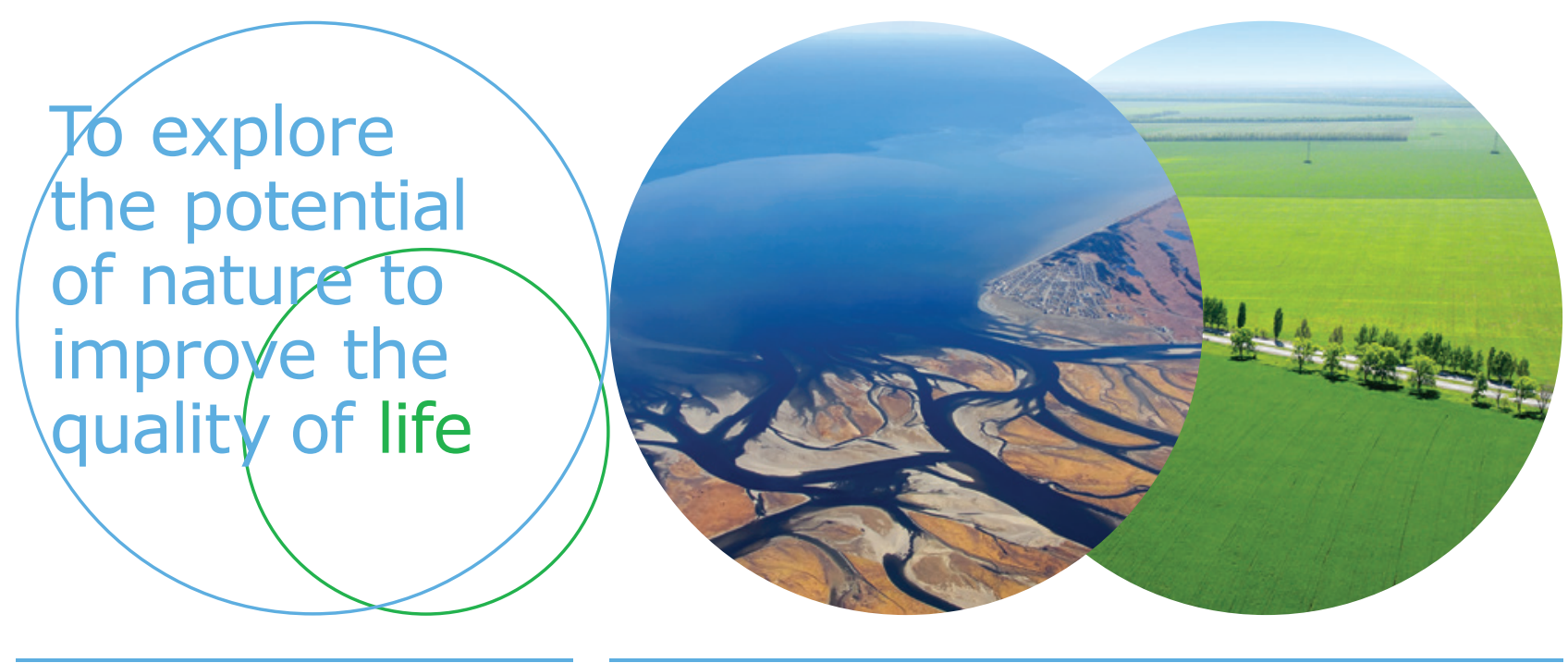

Wageningen Environmental Research Postbus 47

$6700 \mathrm{AB}$ Wageningen

T 317480700

www.wur.nl/environmental-research

Rapport 2774

ISSN 1566-7197
De missie van Wageningen University \& Research is 'To explore the potential of nature to improve the quality of life'. Binnen Wageningen University \& Research bundelen Wageningen University en gespecialiseerde onderzoeksinstituten van Stichting Wageningen Research hun krachten om bij te dragen aan de oplossing van belangrijke vragen in het domein van gezonde voeding en leefomgeving. Met ongeveer 30 vestigingen, 5.000 medewerkers en 10.000 studenten behoort Wageningen University \& Research wereldwijd tot de aansprekende kennisinstellingen binnen haar domein. De integrale benadering van de vraagstukken en de samenwerking tussen verschillende disciplines vormen het hart van de unieke Wageningen aanpak. 